\title{
Differentiation of Sediment Source Regions in the Southern Benue Trough and Anambra Basin, Nigeria: Insights from Geochemistry of Upper Cretaceous Strata
}

\author{
Edegbai Aitalokhai Joel ${ }^{1,2 *}$ and Schwark Lorenz $z^{2,3}$ \\ ${ }^{1}$ Department of Geology, University of Benin, Benin City, Nigeria \\ ${ }^{2}$ Institute of Geoscience, Kiel University, Kiel, Germany \\ ${ }^{3}$ WA-OIGC - Department of Earth and Planetary Sciences, Curtin University, Perth, Australia
}

*Corresponding author: Edegbai, Aitalokhai Joel, Department of Geology, University of Benin, Benin City, Nigeria; Tel: +23465743132; Email: aitalokhai.edegbai@ uniben.edu; joel.edegbai@ifg.uni-kiel.de

Received: November 13, 2020; Accepted: November 20, 2020; Published: November 27, 2020

\begin{abstract}
It is widely accepted that the lithic fill of the Anambra Basin, Southern Nigeria was sourced from the reworked pre-Santonian rocks of the Benue Trough. However, this hypothesis cannot account for the large sand volumes within the basin especially as the lithic fill of the Southern Benue Trough comprises mudstones, carbonates and subordinate sandstone units. In this study, we set out to investigate the provenance of the Mamu Formation as well as preSantonian Awgu and Eze-Aku groups by undertaking geochemical evaluation of cuttings from 5-wells spread across the Anambra Basin. The results of the well data, which was integrated with our previously generated data on the western margin of the Anambra basin as well as published data on the eastern margin reveal that the pre-Santonian units are characterized by a lower degree of chemical alteration and were sourced from basement complex rocks. By contrast, the more chemically altered Mamu Formation is sourced from recycled Southern Benue Trough strata, basement complex rocks as well as, anorogenic granites. In addition, the pre-Santonian units show spatio-temporal compositional variability, which is due to a large proportion of detrital contribution accruing from mafic rocks in the latest Cenomanian to early Turonian, whereas from middle Turonian to Coniacian the detrital contribution was more from felsic sources. Furthermore, the observed spatial geochemical variability of the Mamu Formation is adduced to be a consequence of detrital contribution from three source regions: the eastern, western and northern provenance regions. The eastern provenance region is characterized by a stronger mafic signature, low levels of $\mathrm{Nb}, \mathrm{Ta}, \mathrm{Sn}$ and $\mathrm{Ti}$, high levels of $\mathrm{W}, \mathrm{Pb}$ and $\mathrm{Zn}$, strong Pb- $\mathrm{Zn}$ covariation as well as enrichment of $\mathrm{Zn}$ over $\mathrm{Pb}(\mathrm{Pb} / \mathrm{Zn}<1)$, whereas the western and northern regions show higher levels of $\mathrm{Nb}$, Ta, $\mathrm{Sn}$ and Ti. In addition, the western provenance is characterized by higher $\mathrm{Pb}$ over $\mathrm{Zn}(\mathrm{Pb} / \mathrm{Zn}>1)$ and lower $\mathrm{W}$ concentration, which is distinct from the northern provenance with $\mathrm{Pb} / \mathrm{Zn}$ $<1$ and higher $\mathrm{W}$ concentration. Discriminant plots show clear evidence of mixing of provenance regions especially in the Idah- 1 and Amansiodo- 1 well whose sediments show secondary $\mathrm{Pb}$, Sn and $\mathrm{W}$ mineral enrichment respectively.
\end{abstract}

Keywords: Chemical alteration, West African Rift system, mineral enrichment, Trans-Saharan Seaway

\section{Introduction}

Several hypotheses have been put forward to explain the provenance of the Anambra basin's lithic fill. The leading hypothesis posits that the lithic fill of the Anambra Basin was sourced from reworked pre-Santonian rocks of the Benue [1-3]. This is preferred over sourcing from the basement complex in the eastern highlands (Oban Massif and Cameroun highlands) [3,4]. The main drawback of the former is its inability to account for the large sand volumes in the post-Santonian units [5,6], especially the dominantly sandy Ajali Formation since the pre-Santonian rocks in the Southern Benue Trough are predominantly made up of mudstone and limestone units. The latter hypothesis does not convincingly explain the clear evidence of sediment recycling inferred from the textural, mineralogical and geochemical characteristics, which has been observed in the post-
Santonian units [3,7-9]. Besides the aforementioned hypotheses, further data and reports, support that more than one provenance region exists. Petters [28] opined that sediment contribution from the palaeo-River Niger and the Southern Benue Trough exists. This hypothesis has been somewhat reinforced by recent palaeogeographic and palaeo-drainage models [11-12]. Tijani [8], who undertook textural and geochemical analysis of the Ajali Formation, hypothesized a sediment provenance in the Adamawa-Oban Massif highlands as well as from the pre-Santonian strata of the Southern Benue Trough. Our previous findings in the western segment of the Anambra basin [9] using high resolution multidisciplinary techniques suggested some detrital contribution from basement complex rocks in the southwest (minor) as well as the pre-Santonian rocks (major). It is against this background that we undertook this study, which seeks to investigate 
the provenance of the Awgu and Eze-Aku groups, and the Mamu Formation as a basis for deciphering the provenance regions of the Anambra Basin's lithic fill using geochemical data from outcrops in the western and eastern margin $[9,13]$ as well as [14] from 5 wells spread across the Anambra Basin. Furthermore, data from regional geochemical analysis of sediments from streams draining parts of southwestern and northcentral Nigeria, reports from $\mathrm{Pb}-\mathrm{Zn}$ deposits in the Benue Trough $[15,16]$ as well as reports from mineralized pegmatite [17] and biotite granite [18] domains in southwestern and north central Nigeria, respectively, complemented this study.

\section{Geologic Overview}

The Benue Trough is a NE-SW trending depression approximately $1000 \mathrm{~km}$ by $100 \mathrm{~km}$ in dimension, which comprises a suite of depocenters broadly grouped into Northern, Central and Southern Benue Trough (Figure 1) $[19,20]$. It is part of a much larger west and central rift system (WCARS) that formed due to stresses arising from the opening of the South Atlantic Ocean in the Barremian age [19,2124]. The opening of the Equatorial Atlantic Ocean consequent upon the final separation of the African plate from the South American plate in the Albian [25] resulted in flooding of the Southern Benue Trough, leading

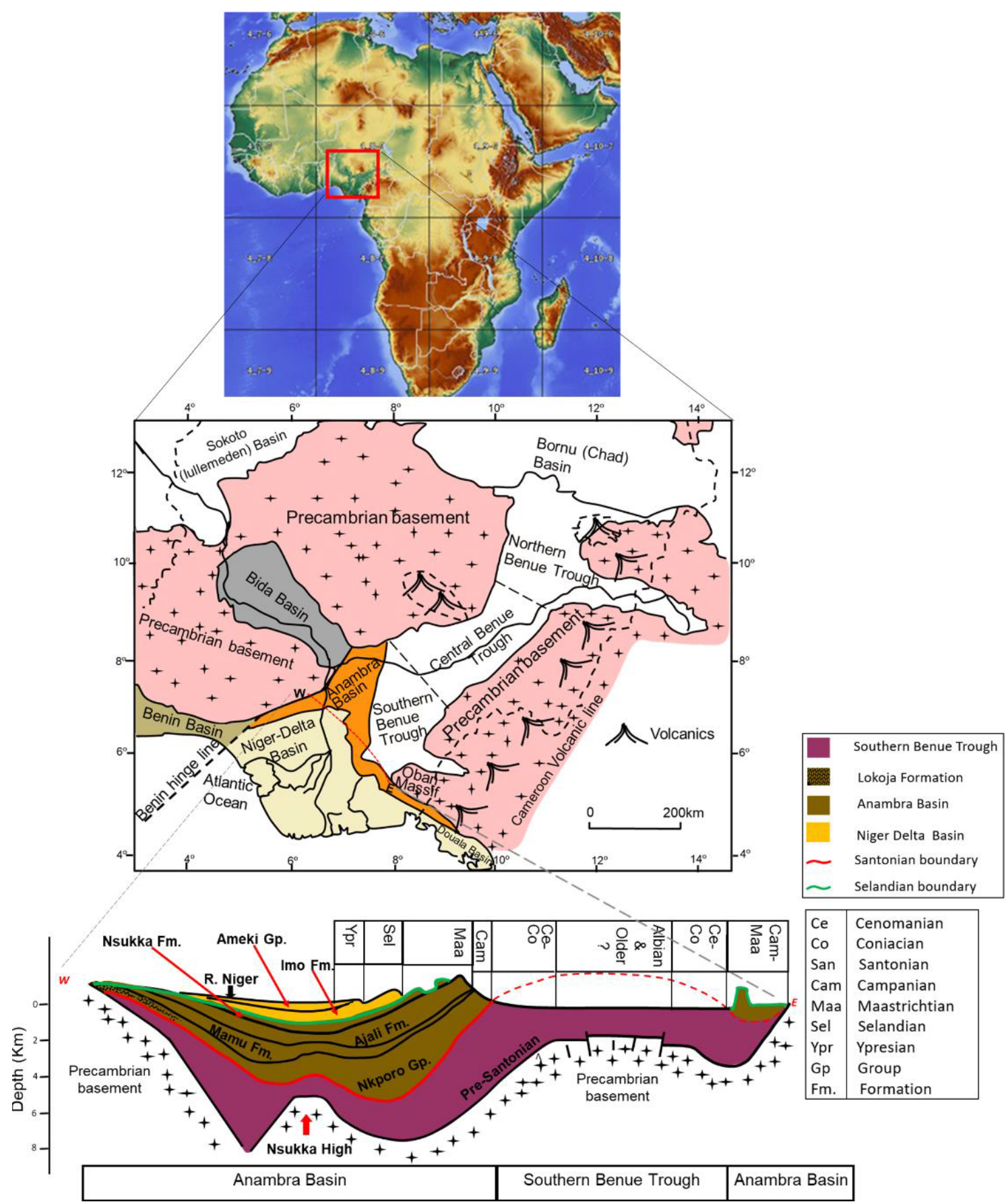

Figure 1: Map of Nigeria showing areas underlain by sedimentary and basement rocks. Below is a W-E cross section showing lithostratigraphic packages of southern Nigeria ranging from Barremian to Ypresian (Edegbai et al., 2019b). 
to the deposition of the Asu-River Group. Due to global sea level rise, this flooding, which peaked in the Cenomanian-Turonian boundary continued into the Turonian [26,27], were floodwaters from the equatorial Atlantic Ocean connected with floodwaters from the Tethys Ocean to establish the Trans-Saharan seaway through the Benue Trough. This resulted in the deposition of the Eze-Aku and Awgu groups [10,28]. The Eze-Aku and Awgu groups belong to one depositional episode spanning latest Cenomanian to Coniacian [28]. Gebhardt [29] reported that these units could only be differentiated based on fossil content. In the southern Benue Trough, the Eze-Aku group comprises chiefly of highly fossiliferous calcareous mudstone intercalated with sands, and limestone units deposited in environments ranging from continental to deep marine environments [30-35]. The Awgu Group consists of limestone, mudstone interstratified with thin limestone and marl units [28], as well as subordinate sands. Coal units, which have been documented at the top of the stratigraphic succession are interpreted to have been deposited in delta plain to marine conditions $[10,20,29]$. The Trans-Saharan Seaway was short lived and eventually broken in the Santonian primarily due to a change in stress regime, which brought about reactivation of NESW trending faults, folding, volcanism as well as exhumation of preSantonian strata of which the southern Benue trough was the most affected [36]. After the Santonian inversion, came a phase of renewed subsidence west of the Southern Benue Trough, which formed the Anambra Basin. The Anambra Basin (Figure 1) represents the sag phase of the Benue Trough evolution. The oldest and youngest parts of its lithic fill comprises the Nkporo Group whose facies is dominantly marine, but shows fluvial to fluvio-marine character at the marginal parts of the basin $[6,20]$ and the brackish Nsukka respectively.

The Mamu Formation comprises mudstone, sand, limestone, carbonaceous and calcareous mudstone, as well as coal and minor ironstone units, which exhibit spatio-temporal variability with respect to thickness and facies [10,32,37-40]. In recent times, these units have been adduced to represent estuarine to shallow marine depositional conditions [10,37,39]. In addition, variable ages ranging from middle Maastrichtian in the North [32] to late Campanian to middle Maastrichtian in the South implying later sedimentation of the Mamu in northern Anambra-Basin have been reported (Figure 2) $[32,38,41]$.

\section{$\underline{\text { Materials and Methods }}$}

\section{Elemental Analysis}

Ninety drill cuttings and core samples from the Nzam-1, Idah1, Owan-1, Amansiodo-1 wells (Figure 3a-3g) representing the postSantonian Mamu Formation as well as the pre-Santonian Eze-Aku and Awgu groups were obtained from the Nigerian Geological Survey Agency storage Core Repository at Kaduna, Nigeria. A combination of cluster and systematic sampling techniques (modified by sample availability and stratigraphic control based on well logs and original reports from oil companies) was employed. Sample preparation entailed homogenization and mechanical pulverization into powder, succeeded by near total multi-acid digestion and elemental analysis using ICP-MS at Activation Laboratories, Ontario, Canada.

\section{Results}

The results of major and trace element analysis were integrated before comparison with previously generated data from outcrops located at the western flank of the Anambra Basin by the authors [some of which have been published [9] as well as data from the eastern margin [13]. As observed [42], argillaceous sediments and fine sands better preserve the provenance signature of source units than coarser units. Consequently, for the purpose of our study, only data from the outcropping dark mudstone lithofacies in the western flank, which has been subdivided into marsh, bay and central basin subenvironments in order of proximality [9], was integrated with data from the drill cuttings. A summary of the elemental analysis results is presented in Appendix 1a-c.

\section{Major Elements (Ca, Fe, Mg, Mn, Ti and Al)}

\section{Outcropping Mamu Formation}

On the western margin, $\mathrm{Al}$ and $\mathrm{Fe}$ are the most abundant major elements in the sediment samples (Appendix 1a, Figure 4a-b). 65.2 $\%, 95.7 \%, 96.1 \%$ of samples from the marsh, bay and central basin subenvironments are above the average upper continental crust [UCC, 43] limit for Al. All samples from the marsh subenvironment have concentrations below the UCC limit for Fe (UCC $=3.5 \%$ ), whereas $50 \%$

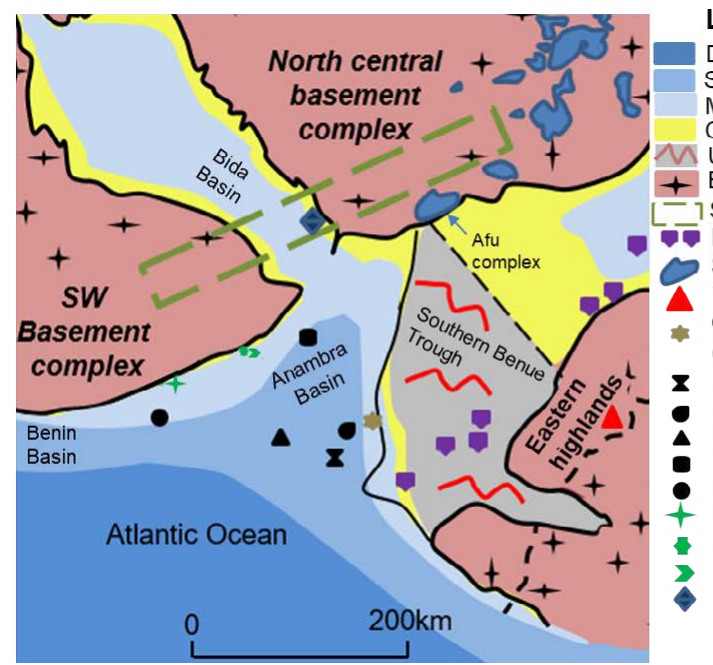

\section{Legend}

Deep marine realm

Shallow marine realm

Marginal marine realm

Continental realm

Uplifted basin

Basement complex highland

$\mathrm{Sn}-\mathrm{Ta}-\mathrm{Nb}$ mineralized pegmatite trend (Kinnaird, 1983)

$\mathrm{Pb}-\mathrm{Zn}$ deposits

$\mathrm{Sn}-\mathrm{Ta}-\mathrm{Nb}$ mineralized anorogenic granites

W- bearing pegmatite (Edem et al., 2015, 2016)

Outcrop location on the eastern margin

(Odoma et al., 2015)

Akukwa-ll well location

Amansiodo-1 well location

Nzam-1 well location

Idah-1 well location

Owan-1 well location

Outcrop location (Marsh samples)

Outcrop location (Central basin samples)

Outcrop location (Bay samples)

Patti Formation (Nton and Adamolekun, 2016)

Figure 2: Conceptual early Maastrichtian paleogeographic model with sample locations, ore deposits and mineralized granites or pegmatites. 

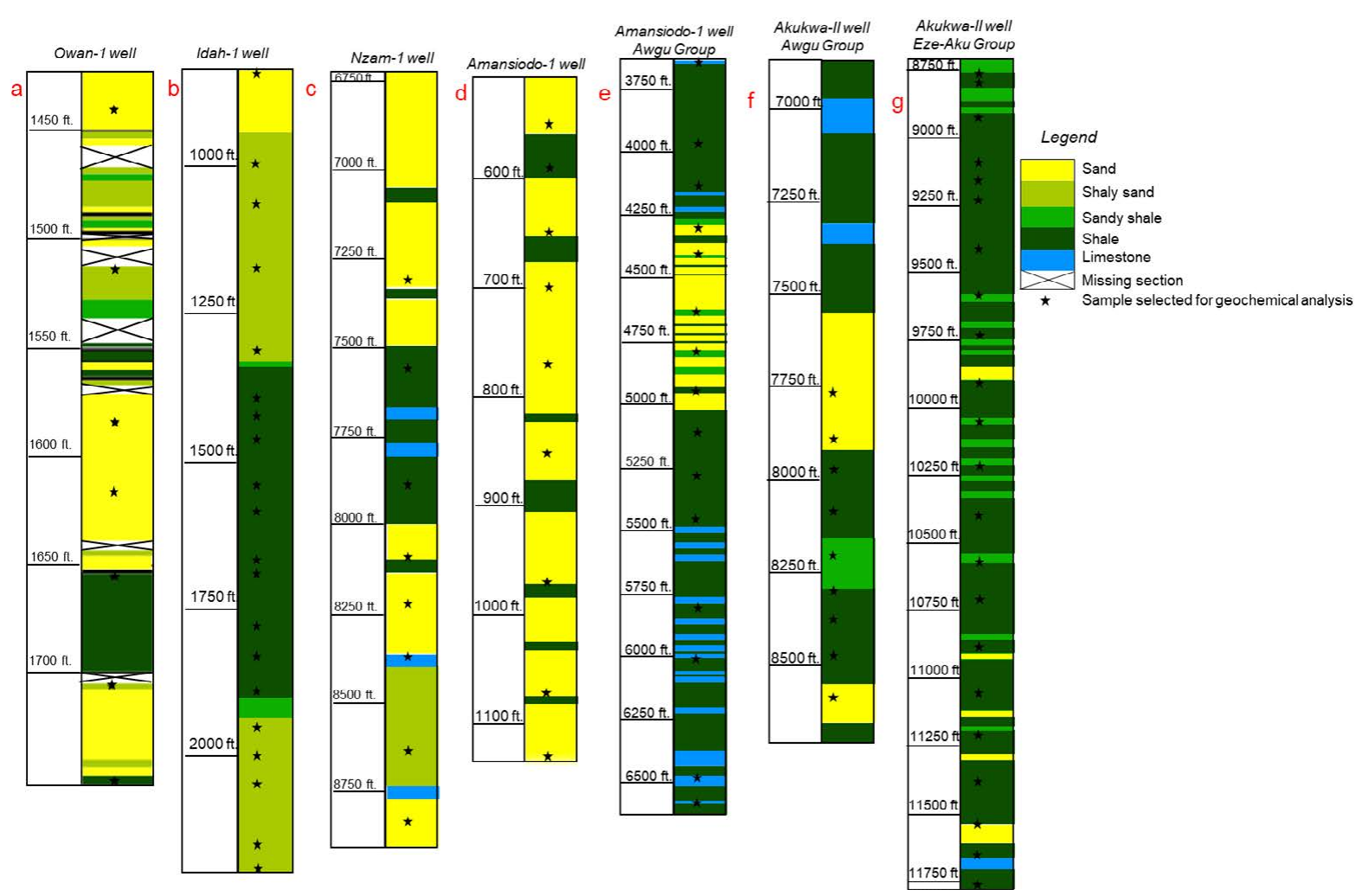

Figure 3: a-d, Lithology of the Mamu Formation penetrated by Owan-1, Idah-1, Nzam-1 and Amansiodo-1 wells respectively. e-f, Lithology of the Awgu Group penetrated by the Amansiodo-1 and Akukwa-II wells. g, Lithology of the Eze-Aku Group penetrated by the Akukwa-II well. See Edegbai, et al., (2019b) for the lithology of outcropping units of the Mamu Formation on the western margin.

and $91.3 \%$ of the samples from the central basin and bay subenvironments, respectively fall below the UCC limit for Fe. While all samples have concentrations below the UCC limits for $\mathrm{Ca}, \mathrm{K}, \mathrm{Mg}$, and $\mathrm{Na}$ (UCC $=3 \%$, $2.8 \%, 1.33 \%$, and $2.89 \%$ respectively), the Ti concentrations are above the UCC composition (UCC $=0.41 \%$ ) (excluding one outlier from the central basin subenvironment). Outcrop data [13] for the eastern margin suggests that $\mathrm{Al}$ and $\mathrm{Fe}$ are the most abundant major elements (Appendix 1a, Figure $4 \mathrm{a}-\mathrm{b}$ ). The concentrations of $\mathrm{Ca}, \mathrm{K}, \mathrm{Mg}$ and $\mathrm{Na}$ concentration in the samples are below the respective UCC limits. $88.9 \%$ and $66.7 \%$ of the samples have $\mathrm{Al}$ and Fe concentrations below the respective UCC, while all the samples have Ti concentration above the UCC for Ti (Appendix 1a, Figure $4 \mathrm{a}-\mathrm{b}$ ). In broad terms, the more distal and saline central basin subenvironment shows the highest concentration of $\mathrm{Ca}, \mathrm{Fe}, \mathrm{K}, \mathrm{Mg}, \mathrm{Mn}$, $\mathrm{Na}$ and $\mathrm{Al}$ in all the dark mudstone samples (Appendix 1a, Figure 4ab). These are very similar in their median values to those reported [13] (Appendix 1a, Figure 4a-b), whereas the lowest concentrations are recorded from the more proximal less saline marsh subenvironment (Appendix 1a, Figure 4a-b).

\section{Well Data}

\section{Mamu Formation}

Aluminium and $\mathrm{Fe}$ are the most abundant among the major elements (Appendix 1a, Figure 4a-b). In the Owan-1 well, all samples are below the UCC limits for $\mathrm{Ca}, \mathrm{Fe}, \mathrm{K}, \mathrm{Mg}$, and $\mathrm{Na}$, while $71.4 \%$ and $14.3 \%$ of the samples have concentrations above the respective UCC limits for Ti and Al. All samples from the Amansiodo-1 well have $\mathrm{Fe}, \mathrm{Ti}, \mathrm{Al}, \mathrm{K}, \mathrm{Mg}$, and $\mathrm{Na}$ concentrations below the respective
UCC limits. In addition, $33.3 \%$ of the samples have Ca concentration above the UCC limit. All the samples from the Idah-1 and Nzam-1 wells have concentrations below the UCC limits for $\mathrm{Ca}, \mathrm{K}, \mathrm{Mg}$ and $\mathrm{Na}$. Furthermore, all the samples from the Nzam-1 well have Ti concentrations above the UCC limit, as do bulk of the samples (90.5\%) from the Idah-1 well. With respect to $\mathrm{Fe}$ and $\mathrm{Al}$ concentrations, $87.5 \%$ and $75 \%$ of samples from the Nzam- 1 well, as well as $85.7 \%$ and $61.9 \%$ of samples from the Idah- 1 well have $\mathrm{Fe}$ and $\mathrm{Al}$ concentrations greater than the respective UCC. The data from Amansiodo-1 (closest to the eastern boundary) and the Owan-1 (on the western margin) wells show very distinct major element distribution in comparison to results from the more central Nzam-1 and Idah-1 wells. The Amansiodo-1 samples possess the largest median concentrations of $\mathrm{Ca}$ as well as much lower concentrations of the other major elements. The median values of the major element data from Owan-1 are very comparable with the marsh outcrop samples, which are also depleted in $\mathrm{Ca}$ and Mg (Appendix 1a, Figure 4a-b). The samples from Idah-1and Nzam1 wells show greater $\mathrm{Ca}, \mathrm{Fe}, \mathrm{K}, \mathrm{Mg}, \mathrm{Mn}, \mathrm{Na}$ and $\mathrm{Ti}$ concentrations (Appendix 1a, Figure 4a-b), in comparison to data from the marginal wells. Furthermore, the Idah-1 well also shows subtle variation in major element concentration when compared to the southern Nzam1 well. Greater concentrations of $\mathrm{Ca}, \mathrm{Mg}, \mathrm{Mn}$ and $\mathrm{Ti}$ abound in the Idah-1well in comparison to the Nzam-1 well, which shows greater concentrations of K, Na and $\mathrm{Al}$ (Appendix 1a, Figure 4a-b).

\section{Pre-Santonian Units.}

Aluminum and $\mathrm{Fe}$ are the most abundant major elements in the samples from the Awgu Group (Appendix 1a, Figure 4a-b). Whereas 

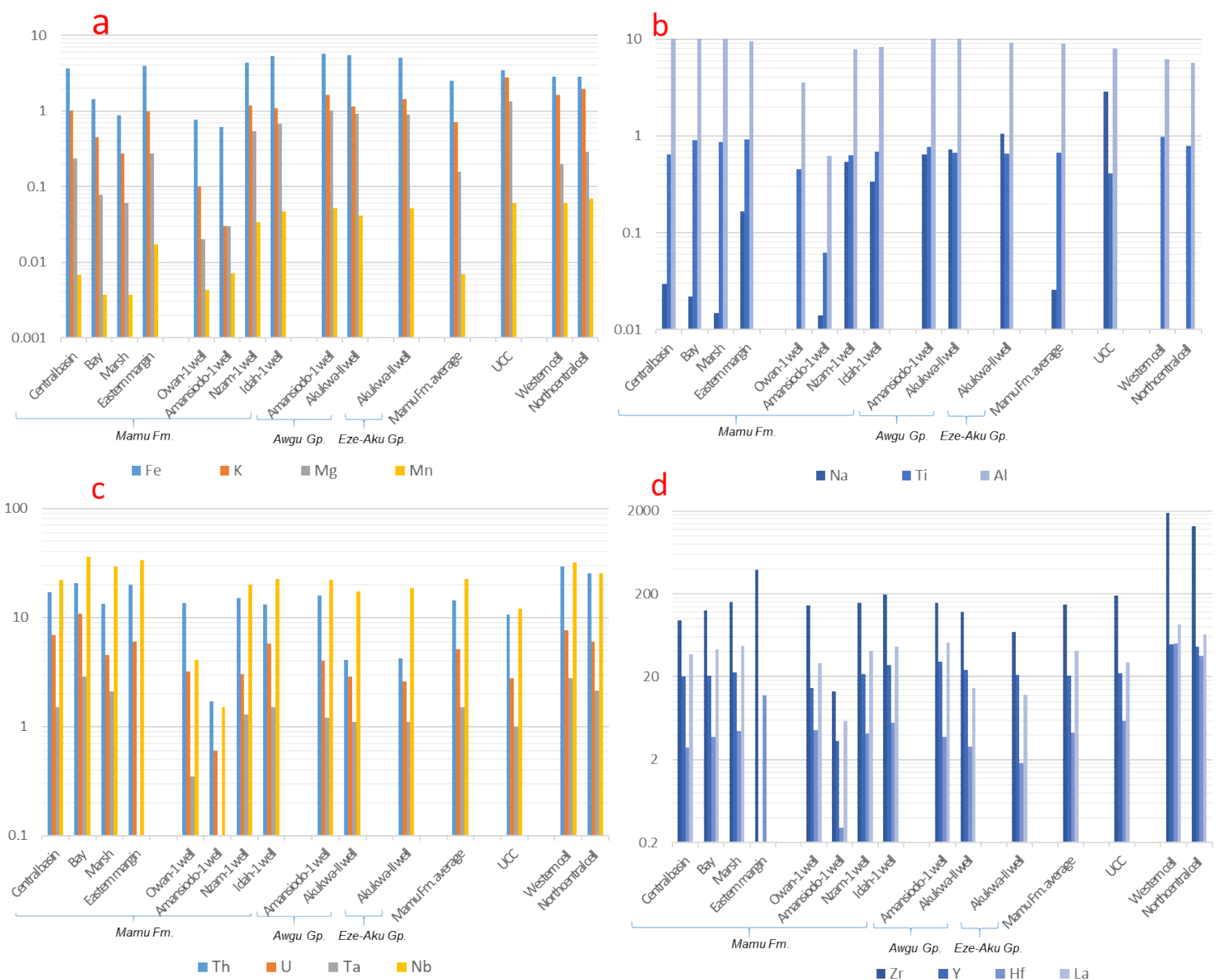

Figure 4: Variograms showing the median concentrations of major and high field strength elements for all sample locations as well as regional data from western and northcentral Nigeria (Lapworth et al., 2012).

all samples show $\mathrm{Fe}, \mathrm{Ti}$ and $\mathrm{Al}$ concentrations above the respective UCC limits (except an outlier from the Akukwa-II well), the concentrations of $\mathrm{Ca}, \mathrm{K}, \mathrm{Mg}$ and $\mathrm{Na}$ in the samples (except an outlier from the Amansiodo-1 well) remain below their respective UCC limits (Appendix 1a, Figure 4a-b). Furthermore, the major element distribution in the Awgu Group shows slight variability. Whereas samples from the Amansiodo-1 well are slightly more enriched in $\mathrm{Fe}$, $\mathrm{K}, \mathrm{Ti}$ and $\mathrm{Al}$, the Akukwa-II well samples are slightly more enriched in $\mathrm{Ca}$ and $\mathrm{Na}$ (Appendix 1a, Figure 4a-b). In the Eze-Aku Group, $\mathrm{Al}$ and $\mathrm{Fe}$ are the most abundant major elements (Appendix 1a, Figure 4a-b). All the samples show $\mathrm{K}$ and $\mathrm{Na}$ concentrations below their respective UCC limits, while $85 \%$ and $95.2 \%$ of the samples have Ca and $\mathrm{Mg}$ concentrations below the respective UCC limits. In addition, the concentration of $\mathrm{Fe}$ and $\mathrm{Al}$ in the bulk of the samples is above the UCC limit. In general, samples from the Eze-Aku Group show slight enrichment in $\mathrm{Na}$ and $\mathrm{Ca}$ over the samples from the Awgu Group that reveal higher concentrations of $\mathrm{Fe}, \mathrm{K}, \mathrm{Mg}$, $\mathrm{Ti}$ and $\mathrm{Al}$. In addition, the major element distribution in the pre-Santonian units are quite comparable to those observed from the centrally positioned Nzam-1 and Idah-1wells (Appendix 1a, Figure 4a-b).

High Field Strength Elements (HFSE: Th, U, Ta, Nb, Zr, Y, Hf)

\section{Outcropping Mamu Formation}

All the dark mudstone samples on the western margin have $U$ and $\mathrm{Nb}$ concentrations above the respective UCC limits (UCC for $\mathrm{U}$ and $\mathrm{Nb}=2.8 \mathrm{ppm}$ and $12.0 \mathrm{ppm}$ respectively) (Appendix 1b, Figure $4 \mathrm{c}-\mathrm{d})$. The Th and Ta concentrations of all the samples from marsh and bay subenvironments, and the bulk of the samples $(92.3 \%$ and $88.5 \%$ respectively) from the central basin subenvironment are above the respective UCC limits for Th $(\mathrm{UCC}=10.7 \mathrm{ppm})$ and $\mathrm{Ta}(\mathrm{UCC}=$ $1 \mathrm{ppm})$. In addition, a very large proportion of the dark mudstone samples have concentrations below the UCC for Zr and Hf (UCC for $\mathrm{Zr}$ and $\mathrm{Hf}=190$ and $5.8 \mathrm{ppm}$, respectively). Furthermore, 56.5\%, $34.8 \%$, and $38.5 \%$ of samples from the marsh, bay and central basin subenvironments respectively have Y concentration above the UCC 
limit $(\mathrm{UCC}=22 \mathrm{ppm})$. On the eastern margin, data from [13], show that all the samples are enriched above the UCC concentration for $\mathrm{Th}, \mathrm{U}, \mathrm{Nb}, \mathrm{Zr}$ and $\mathrm{Hf}$ (Appendix 1b, Figure 4c-d). In general, with the exception of $\mathrm{Zr}$ and $\mathrm{Hf}$, which are much higher, the concentration of the other HFSE being discussed are more comparable to the outcrops at the Benin flank than the well data (Appendix 1b, Figure 4c-d).

\section{Well Data}

\section{Mamu Formation}

As observed in the major element distribution, the Amansiodo-1 well samples show very distinct geochemical distribution of the HFSE (Th, U, Ta, Nb, Zr, Y, and $\mathrm{Hf}$ ) as indicated by very low concentrations that are at least one order lower than those obtained from the outcropping units (Appendix 1b, Figure 4c-d). The HFSE abundance from the Owan-1 well, though much higher than the data from the Amansiodo-1 well, is subordinate to the outcropping units (Appendix $1 b$, Figure $4 c-d)$. In the more centrally located Nzam-1 and Idah1wells, a very large proportion of the samples show enrichment in $\mathrm{Th}, \mathrm{U}, \mathrm{Ta}$, and $\mathrm{Nb}$ above the respective UCC (Appendix 1b, Figure $4 c-d)$. In the Idah- 1 well, $57 \%, 85.7 \%$ and $28.6 \%$ of the samples have concentration above the respective UCC for Zr, Y, and Hf (Appendix $1 b$, Figure $4 c-d)$. The $\mathrm{Zr}$, Y and Hf concentrations that are higher than the outcropping units on the western margin are subordinate to the $\mathrm{Zr}$ and $\mathrm{Hf}$ on the eastern margin [13]. By contrast, the outcropping units on the western margin show more enrichment in Th, $\mathrm{U}, \mathrm{Ta}$, and $\mathrm{Nb}$ than the sediments in the Nzam-1 and Idah-1wells (Appendix $1 b$, Figure 4c-d). Furthermore, with the exception of Th, the median concentrations of the HSFE being discussed decreases from samples from Idah-1 well location to the samples from Nzam-1 well (Appendix 1 b, Figure 4c-d). In the Nzam-1 well, the bulk of the samples, which show enrichment in Th, $\mathrm{U}, \mathrm{Ta}$ and $\mathrm{Nb}$ above the respective UCC limit, show depletion in $\mathrm{Zr}$, Y, and Hf concentrations.

\section{Pre-Santonian units}

The Awgu Group samples from the Amansiodo-1 well show more enrichment in Th, $\mathrm{U}, \mathrm{Ta}, \mathrm{Nb}, \mathrm{Zr}, \mathrm{Y}$ and $\mathrm{Hf}$ in comparison to samples from the Akukwa-II well (Appendix 1b, Figure 4c-d). The median values of the HFSE are comparable to the Mamu Formation data from the Idah-1and Nzam-1 wells. In addition, a large proportion of the samples from the Amansiodo-1 well show enrichment above the respective UCC for Th, U, Ta and $\mathrm{Nb}$ and Y (Appendix 1b, Figure 4cd). Conversely, the samples are depleted below the respective UCC composition for $\mathrm{Zr}$ and $\mathrm{Hf}$ (Appendix 1b, Figure 4c-d). A much lower proportion of the samples from the Akukwa- II well show enrichment above the respective UCC limits for $\mathrm{U}, \mathrm{Ta}, \mathrm{Nb}$ and Y. Furthermore, none of the samples are enriched above the UCC concentrations for $\mathrm{Th}, \mathrm{Zr}$ and Hf (Appendix 1b, Figure 4c-d). In broad terms, when compared with the post-Santonian Mamu Formation (excluding the samples from Owan-1 well and the Amansiodo-1 well), the Awgu Group is depleted in Th, U, Ta, Nb, Zr and Hf concentrations (Appendix 1b, Figure 4c-d). In contrast, the concentration of La and Y is much higher than in post-Santonian units (Appendix 1b, Figure 4cd). The bulk of the samples from the Eze-Aku Group show depletion in $\mathrm{Th}, \mathrm{U}$ and Hf concentrations below the respective UCC composition
(Appendix 1b, Figure 4c-d). In addition, none of the samples show enrichment in $\mathrm{Zr}$ and $\mathrm{Hf}$ above the respective UCC limits (Appendix $1 b$, Figure $4 c-d)$. Conversely, a larger proportion of the samples are enriched in $\mathrm{Ta}$ and $\mathrm{Nb}$ above the respective UCC limits. The HFSE distribution within the Eze-Aku Group is very comparable to the data from the Awgu Group in the Akukwa II well, except that much lower $\mathrm{Zr}$ concentrations are present (Appendix 1b, Figure 4c-d).

\section{Transition Trace Elements [(TTE) Ni, Co, V, Cr and Sc)]}

\section{Outcropping Units}

A large proportion of the marsh and bay samples are depleted in $\mathrm{Ni}, \mathrm{Co}$ and $\mathrm{Sc}$ content. Conversely, the bulk of the samples show enrichment in $\mathrm{Cr}$ (Appendix 1b, Figure 5a-b). There is a distinction in the $\mathrm{V}$ content of the marsh and bay samples. Whereas the bulk of the Marsh samples are enriched above the UCC limit for V (UCC = $107 \mathrm{ppm}$ ), only $8.7 \%$ of the Bay samples show $\mathrm{V}$ enrichment above the UCC limit. In comparison to the marsh and bay units, the central basin samples are much more enriched in TTE, only subordinate to the marsh unit in V concentration (Appendix 1b, Figure 5a-b). On the eastern margin, data [13] shows depletion of $\mathrm{Ni}$ and $\mathrm{Co}$, whereas a substantial proportion of the samples show enrichment above the $\mathrm{Cr}$ and $\mathrm{Sc}$ of the respective UCC composition (UCC $=83 \mathrm{ppm}$ and 13.6 ppm, respectively) (Appendix 1b, Figure 5a-b). In addition, $44.4 \%$ of the samples are enriched above the UCC mean for V. In general, the central basin unit shows the most enrichment in TTE when compared with the other outcrop units (Appendix 1b, Figure 5a-b), which is perhaps due to the redox conditions prevailing. The $\mathrm{V}$ and $\mathrm{Cr}$ content in the eastern margin is much lower than the marsh and central basin units in the western margin are (Appendix 1b, Figure $5 \mathrm{a}-\mathrm{b})$. Furthermore, excluding the central basin unit, all other outcrop samples are depleted in $\mathrm{Ni}$ and Co concentrations (Appendix 1b, Figure 5a-b).

\section{Well Data}

\section{Mamu Formation}

The TTE distribution in samples from the Owan-1 and Amansiodo-1 wells are very distinct from the more centrally located wells due to their lower TTE concentrations. The samples from the Nzam-1 well show significant enrichment above the samples from the Idah-1well (Appendix 1b, Figure 5a-b). The Ni concentration in majority of the well samples are below the UCC limit $(\mathrm{UCC}=44 \mathrm{ppm})$. In addition, while the $\mathrm{V}, \mathrm{Cr}$ and $\mathrm{Sc}$ abundances of all samples from the Owan-1 and Amansiodo-1 wells as well as the majority of the samples from the Idah-1well fall below the respective UCC composition (Appendix 1b, Figure 5a-b), the Co content in the majority of the samples are above the UCC mean (UCC $=17 \mathrm{ppm})$. In general, the outcropping units on the western margin contain higher levels of $\mathrm{V}$, $\mathrm{Cr}$ and Sc than their well counterparts (Appendix 1b, Figure 5a-b).

\section{Pre-Santonian Units}

Excluding the $\mathrm{Cr}$ concentration, which is depleted in the samples from Akukwa - II well, the TTE distribution in the Awgu Group is quite similar with a dominance of samples enriched above the respective 
a

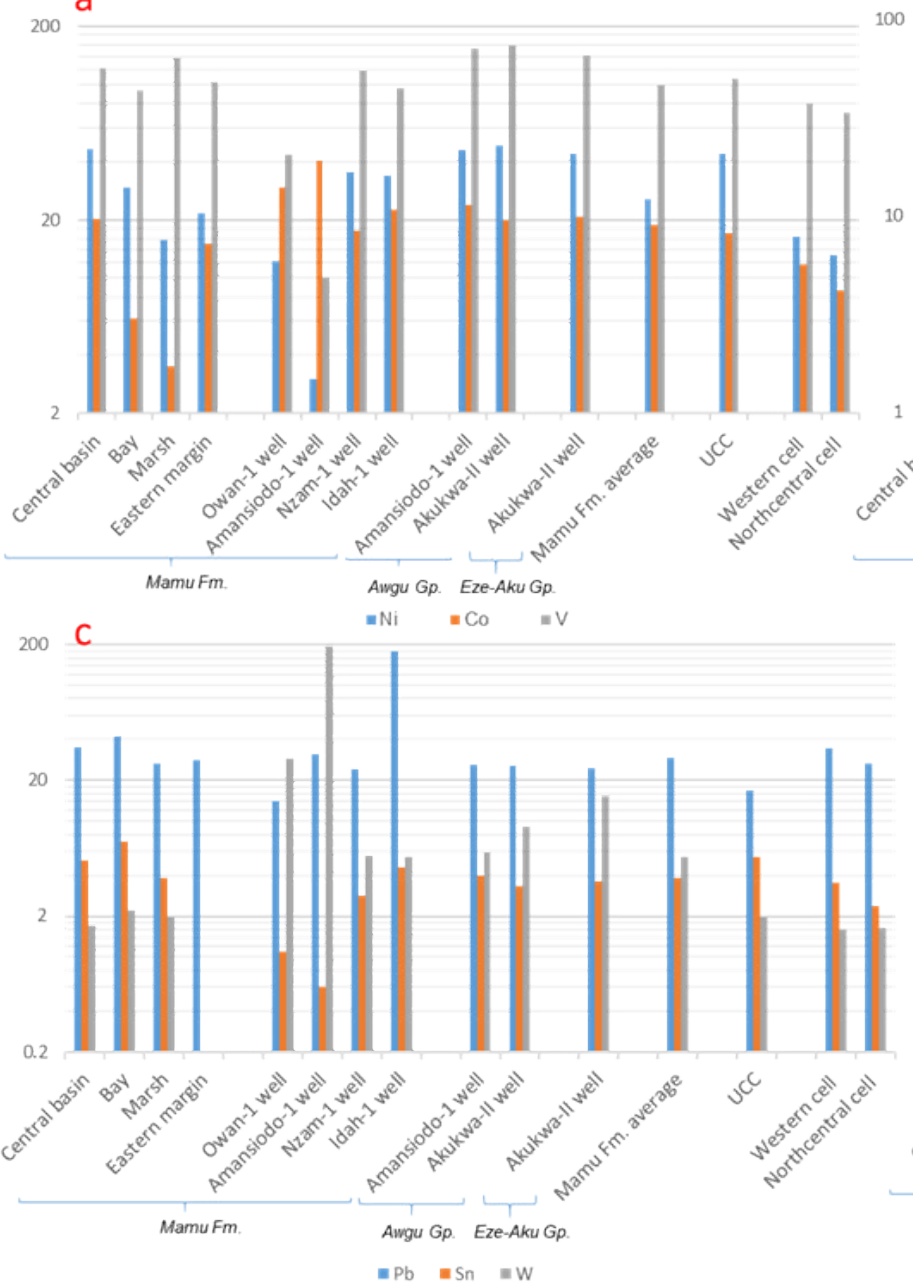

b

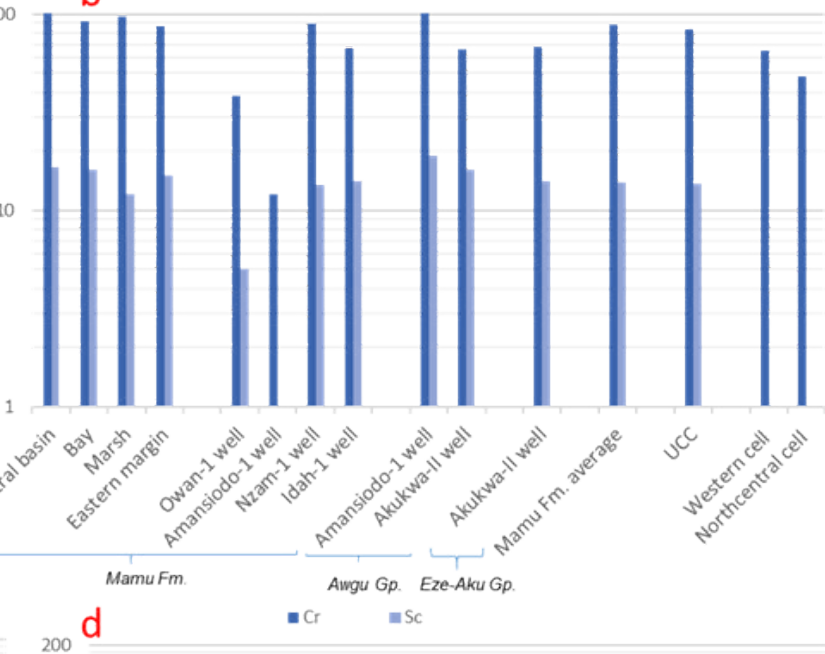

\author{
.
}


above the UCC limits for $\mathrm{Pb}$ and $\mathrm{Zn}$ (Appendix 1a, Figure $5 \mathrm{c}-\mathrm{d}$ ). The samples from Idah-1well in particular shows very high levels of $\mathrm{Pb}$ and $\mathrm{Zn}$ as well as $\mathrm{Sn}$ in some intervals. The Owan-1 and Amansiodo-1 wells show some distinction, as a large proportion of the samples from both wells is depleted in $\mathrm{Zn}$ when compared with the centrally located wells (Appendix 1a, Figure $5 c-d$ ). In addition, all the samples from the Amansiodo-1 well show enrichment above the UCC for $\mathrm{Pb}$, whereas only $28.6 \%$ of samples from the Owan- 1 well have $\mathrm{Pb}$ concentration above the UCC.

\section{Pre-Santonian Units}

All the samples from the Awgu Group across the wells are enriched in $\mathrm{Pb}, \mathrm{W}$ and $\mathrm{Zn}$ above the respective UCC, whereas by contrast, are depleted in $S n$ (Appendix 1a, Figure $5 c-d$ ). The samples from Akukwa-II well show higher levels of $\mathrm{Zn}, \mathrm{W}$, $\mathrm{Mo}$ and $\mathrm{Cu}$, thus contrasting with samples from the Amansiodo-1 well. In addition, nearly all the samples from the Akukwa-II well are enriched above the UCC limits for $\mathrm{Mo}$ and $\mathrm{Cu}$, whereas a lower proportion of samples from the Amansiodo- 1 well (60\% and 53.3\% respectively) are enriched above the respective UCC. A very large proportion of the samples from the Eze-Aku Group show enrichment in $\mathrm{Pb}, \mathrm{W}, \mathrm{Zn}, \mathrm{Mo}$, and $\mathrm{Cu}$, whereas all the samples are depleted in Sn (Appendix 1a, Figure 5cd). In addition, the Eze-Aku group is more enriched in Mo, W, and $\mathrm{Zn}$ when compared with samples from the Awgu Group. In general, the pre-Santonian units show enrichment in $\mathrm{W}, \mathrm{Zn}, \mathrm{Mo}$, and $\mathrm{Cu}$ when compared with data from the post-Santonian Units (Appendix 1a, Figure $5 c-d)$. There is significantly more enrichment of $\mathrm{Pb}$ in the Mamu Formation when compared with data from the pre-Santonian Awgu and Eze-Aku Groups.

\section{Discussion}

\section{Degree of Chemical Alteration}

The order of stability of major elements [44] implies that $\mathrm{Si}, \mathrm{Fe}$, $\mathrm{Ti}$ and $\mathrm{Al}$ are the most stable elements. Thus, the proportion of major elements can provide some clues as to the degree of chemical alteration in the source region. The most depleted elements are $\mathrm{Na}, \mathrm{Ca}$, and $\mathrm{Mg}$ indicative of a high degree of initial weathering, except in the case of the Eze-Aku Group in the Akukwa-II well and the Mamu Formation in Amansiodo-1 well that are enriched in non-silicate $\mathrm{Ca} . \mathrm{Na} / \mathrm{K}, \mathrm{Mg} / \mathrm{K}$, $\mathrm{K} / \mathrm{Al}$ and $\mathrm{Na} / \mathrm{Al}$, which reflects the proportion of less stable minerals like plagioclase, biotite, chlorite, smectite, vermiculite and illite relative to more stable K-feldspar, illite and Kaolinite have been shown to track the degree of weathering of crustal material [45]. A higher degree of chemical alteration is inferred for the outcropping units on the western and eastern margins as well as the samples from the Owan well based on the low $\mathrm{Na} / \mathrm{Al}, \mathrm{K} / \mathrm{Al}, \mathrm{Mg} / \mathrm{K}$ and $\mathrm{Na} / \mathrm{K}$. This is illustrated further by the major element distribution $[(\mathrm{Na}, \mathrm{Ca}, \mathrm{Mg})<\mathrm{K}<\mathrm{Ti}<\mathrm{Fe}<\mathrm{Al}]$ as well as low $\mathrm{Mg} / \mathrm{Ti}$ (Appendix 1a, c Figure . 4a-b, 6a-c). In addition, higher $\mathrm{Na} / \mathrm{Al}, \mathrm{K} / \mathrm{Al}, \mathrm{Mg} / \mathrm{K}$ (Appendix 1c, Figure $6 \mathrm{c}$ ) recorded for the central basin mudstones as well as the samples from the eastern margin [13] suggests relatively lower degrees of chemical alteration. This is adduced to authigenic illite and smectite formation arising from an increase in salinity [9]. Furthermore, in comparison with the outcropping units, data from the Amansiodo- 1 well as well as the more centrally placed
Nzam-1 and Idah-1wells show much higher $\mathrm{Na} / \mathrm{Al}, \mathrm{K} / \mathrm{Al}, \mathrm{Mg} / \mathrm{K}$, $\mathrm{Na} / \mathrm{K}, \mathrm{Mg} / \mathrm{Ti}$ values (Appendix 1c, Figure 6c). This indicates a lower degree of chemical alteration regardless of carbonate dilution (calcite cement) in the Amansiodo- 1 well $(\mathrm{Na}<\mathrm{K}<\mathrm{Mg}<\mathrm{Ti}<\mathrm{Al}<\mathrm{Fe}<\mathrm{Ca})$ that has modified the major element distribution pattern. We hypothesize that the higher salinities in these areas as suggested by early Maastrichtian paleogeographic reconstruction [6] may account for some increment in the $\mathrm{Na} / \mathrm{Al}, \mathrm{K} / \mathrm{Al}, \mathrm{Mg} / \mathrm{K}, \mathrm{Na} / \mathrm{K}, \mathrm{Mg} / \mathrm{Ti}$ values as well as the extent of mixing from provenance regions (discussed in section 5.3). In addition, data from the eastern margin as well as the central basin mudstones, which show higher $\mathrm{K}$ relative to $\mathrm{Ti}$ (which increases with higher $\mathrm{Mg} / \mathrm{Ti}$ ) further illustrates this. The data from the Awgu Group is comparable to those observed in the Nzam-1 and Idah-1 wells) except in $\mathrm{Mg} / \mathrm{Ti}$, which is much higher (Appendix 1c, Figure 6c). The observed major element trend $(\mathrm{Ca}<\mathrm{Na}<\mathrm{Ti}<\mathrm{Mg}<\mathrm{K}<\mathrm{Fe}<\mathrm{Al})$ at the Amansiodo- 1 well is distinct from that of the Awgu $(\mathrm{Ca}<\mathrm{Ti}<\mathrm{Na}<\mathrm{Mg}<\mathrm{K}<\mathrm{Fe}<\mathrm{Al})$ and EzeAku $(\mathrm{Ti}<\mathrm{Mg}<\mathrm{Na}<\mathrm{K}<\mathrm{Ca}<\mathrm{Fe}<\mathrm{Al})$ groups observed at the AkukwaII well, which have lower Ti relative to $\mathrm{Na}, \mathrm{Mg}$ and $\mathrm{K}$ (Appendix 1a, Figure $4 a-b, 6 c)$. This implies a higher degree of chemical alteration of the Awgu Group in the Amansiodo well. In general, regardless of carbonate dilution in the samples from the Eze-Aku Group, we can infer that a much lower degree of chemical alteration and consequently mineralogical immaturity persists in the pre-Santonian units when compared with the Mamu Formation. This is based on the much higher $\mathrm{Na} / \mathrm{Al}, \mathrm{K} / \mathrm{Al}, \mathrm{Mg} / \mathrm{K}, \mathrm{Na} / \mathrm{K}, \mathrm{Mg} / \mathrm{Ti}$ (Appendix 1c, Figure $6 \mathrm{c}$ ), as well as higher percentages of smectite, illite and mixed layered clays reported for these units, in comparison to those reported for the Mamu Formation $[7,9,28]$. Furthermore, our findings are consistent with published results of petrographic analysis, which reported textural and mineralogical immaturity of the pre-Santonian units as distinct from the more texturally and mineralogically mature post-Santonian units of which the Mamu Formation subsists $[3,5,7,46]$. This is in spite of the humid equatorial climatic conditions that prevailed at during the Cenomanian-Turonian and Campanian- Maastrichtian stages [47].

\section{Source Rock Composition}

Some trace elements common to felsic and mafic rocks have reduced mobility when subjected to weathering, erosion, transportation, and diagenesis [48-53]. Consequently, their concentrations in sedimentary rocks can give valuable insight in provenance studies [52]. To reduce the uncertainty regarding the accuracy of provenance determination using trace elements, we utilized trace elements whose concentrations are least affected by redox conditions. We assume that the concentration of these conservative trace elements in our samples preserve the geochemistry of the sediment provenance regions. The $\mathrm{Th} / \mathrm{Sc}$ vs. $\mathrm{La} / \mathrm{Sc}, \mathrm{TiO} 2$ vs. $\mathrm{Zr}, \mathrm{Th} / \mathrm{Sc}$ vs. Sc, as well as $\mathrm{Th} / \mathrm{Sc}$ vs. $\mathrm{Zr} / \mathrm{Sc}$ discriminant plots [50,52] (Figure 7a-h) highlight intra- and interformational variation in the geochemical characteristics of the pre-Santonian units and the Mamu Formation, which are useful in determining the chemical composition of source units.

\section{Pre-Santonian Units}

Samples from the pre-Santonian units show a uniform Sc concentration (averaging 15ppm) (Figure 7e-f), whereas the $\mathrm{Th}, \mathrm{Zr}$ and La content of these units are highly variable (Figure 7a-h, Appendix 

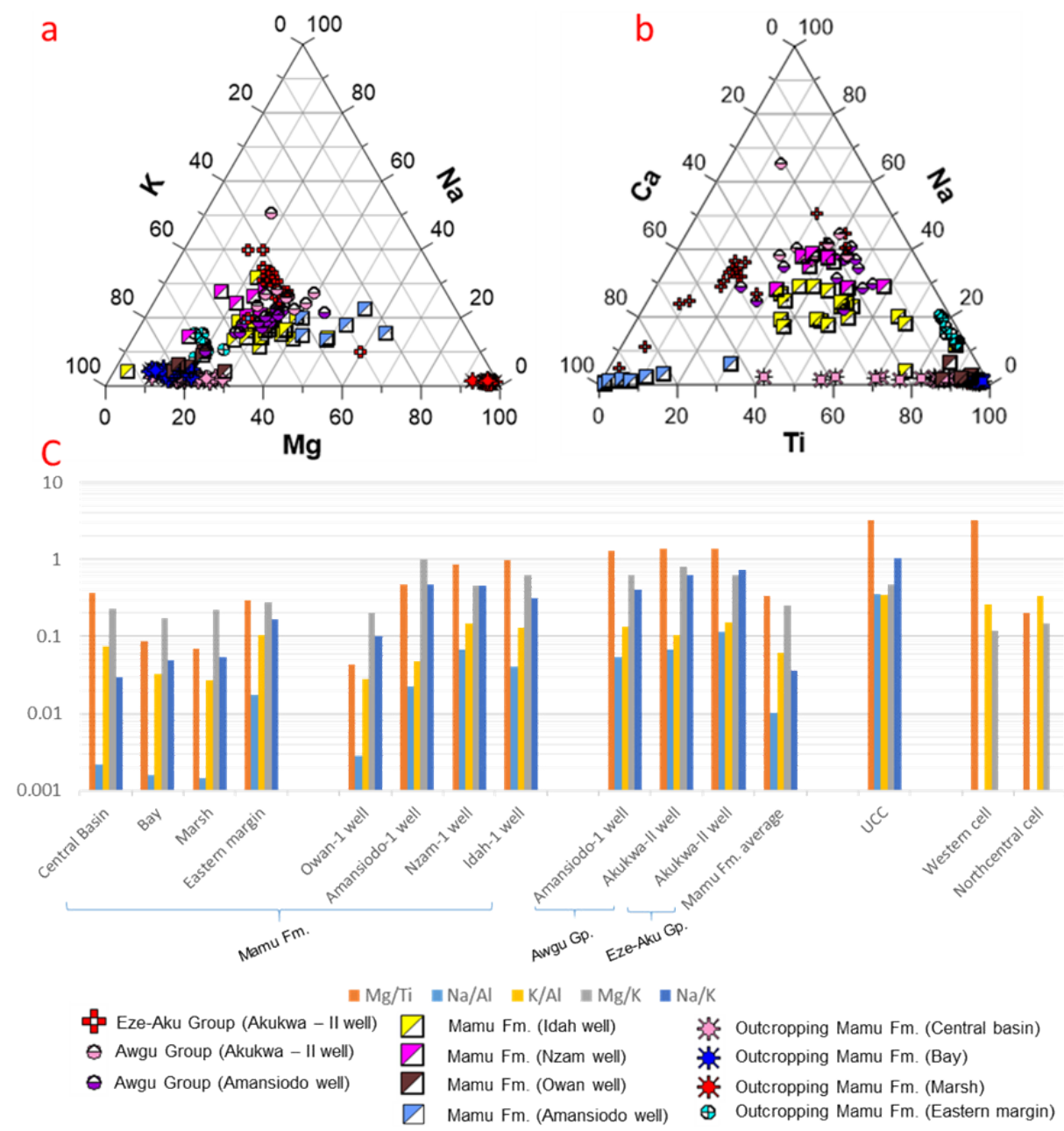

Figure 6: Ternary plots showing the distribution of $\mathrm{K}, \mathrm{Na}, \mathrm{Mg}, \mathrm{Ca}, \mathrm{Na}$ and $\mathrm{Ti}$ concentrations of all sample locations as well as a variogram of median values of $\mathrm{Mg} / \mathrm{Ti}, \mathrm{Mg} / \mathrm{K}, \mathrm{Na} / \mathrm{Al}$, and $\mathrm{K} / \mathrm{Al}$.

1b). The geochemical characteristics of the pre-Santonian units suggests a basement source rock with compositional variability as shown by the $\mathrm{Th} / \mathrm{Sc}<1$ (Figure 7c-f) [50]. This is illustrated further by the Th/Sc vs. $\mathrm{Zr} / \mathrm{Sc}$ binary plot [54] (Figure 7g-h), which indicate that these units were not sourced from reworked older sedimentary rocks. Intraformational compositional variability is visible in the Awgu Group (across the Amansiodo-1 and Akukwa-II wells) as well as the Eze-Aku Group. In the Akukwa-II well, a mafic to intermediate source rock composition is inferred due to the much lower Th, Zr, La and other HFSE concentrations, whereas in the Amansiodo-1 well, which has much higher concentration of HFSE, an intermediate to felsic source rock composition is inferred (Appendix 1b, Figure 4c-d, 7a-d). The observed spatial variation in degree of chemical alteration in the Awgu group (highlighted in section 5.1) is in part due to the more felsic nature of the source rocks for the sediments from the Amansiodo-1 well. The Eze-Aku unit shows source rock composition varying from (predominantly) mafic to felsic basement rocks owing to a range of $\mathrm{Th}, \mathrm{Zr}$, and La concentrations, which are the lowest among the pre-Santonian units (Appendix 1b, Figure 4c-d, 7a-d).

\section{Mamu Formation}

Samples from the pre-Santonian units show a non-uniform Sc concentration as well as variable $\mathrm{Th}, \mathrm{Zr}$, and La concentrations. This depicts a (predominant) felsic to intermediate source composition (Figure 7b, d, f) hypothesized to be derived from reworked preSantonian units as well as (predominantly) silica rich igneous and metamorphic rocks. Evidence for recycling of pre-Santonian units is illustrated by a higher degree of chemical alteration (see section 5.1), low index of compositional variability [9], a large proportion of the samples having $\mathrm{Th} / \mathrm{Sc}>1$ (characteristic of recycled sedimentary rocks), as well as inferences from $\mathrm{Th} / \mathrm{Sc}$ vs. $\mathrm{Zr} / \mathrm{Sc}$ and $\mathrm{Th} / \mathrm{Sc}$ vs. Sc (Figure 7f, h) discriminant plots [50,54]. In addition, the better textural and mineralogical maturity reported for the post-Santonian units $[3,5,7,46]$ is attributable to a significant proportion of their provenance originating from reworked pre-Santonian units. Furthermore, Th/Sc $<$ 1 reported for some samples (Appendix 1c), inferences from Th/Sc vs. $\mathrm{Zr} / \mathrm{Sc}$ and $\mathrm{Th} / \mathrm{Sc}$ vs. Sc (Figure $7 \mathrm{f}, \mathrm{h}$ ) discriminant plots [50,53], as well as variability in the degree of chemical alteration (discussed in section 5.1) provides evidence for detrital contribution from silica rich igneous and metamorphic rocks. This is further illustrated by the high concentration of $\mathrm{W}$ reported for the sediments (especially in the Owan-1, Amansiodo-1 and Idah-1 wells) (see section 5.3), which are much higher than those recorded for the pre-Santonian units points to detrital contribution from basement rocks, as $\mathrm{W}$ is not known to survive several weathering and sedimentation cycles [18]. 

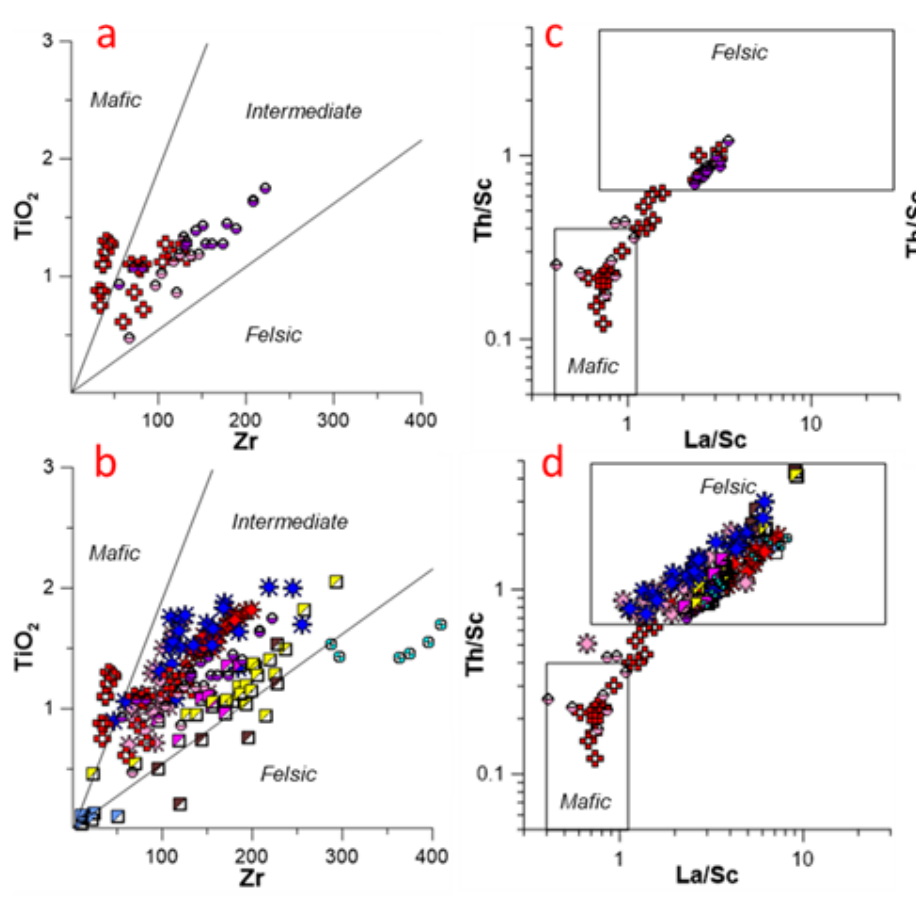

$$
\begin{aligned}
& \text { Eze-Aku Group (Akukwa - II well) } \\
& \ominus \text { Awgu Group (Akukwa - II well) } \\
& \text { Awgu Group (Amansiodo well) }
\end{aligned}
$$

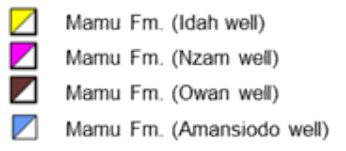

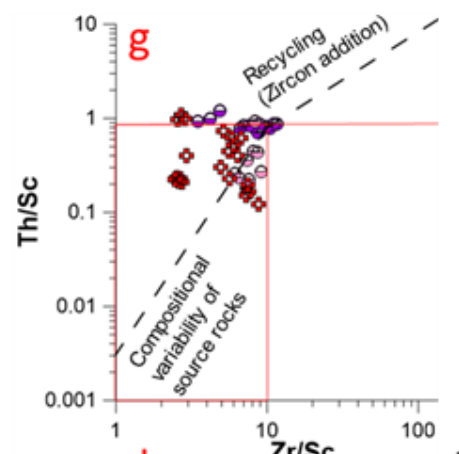
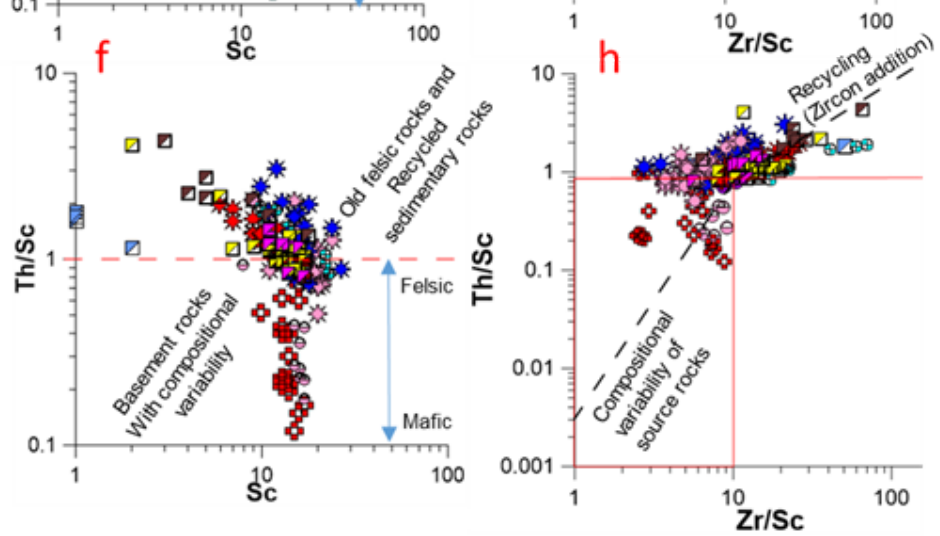

次 Outcropping Mamu Fm. (Central basin)

类 Outcropping Mamu Fm. (Bay)

Outcropping Mamu Fm. (Marsh)

$\oplus$ Outcropping Mamu Fm. (Eastern margin)

Figure 7: $\mathrm{TiO}_{2}$ vs. $\mathrm{Zr}$ (a-b) (after Hayashi et al., 1997), Th/Sc vs. La/Sc (c-d) (after Cullers, 2000) and binary plots showing source composition of the pre-Santonian units as well as the Mamu Formation. Th/Sc vs. Sc (after McLennan and Taylor, 1991) (e-f) and Th/Sc vs. Zr/Sc (g-h) (McLennan et al., 1993) binary plots indicate variable basement sources for pre-Santonian strata as well as a combination of felsic basement rocks and recycled pre-Santonian strata sources for the Mamu Formation.

\section{Provenance}

Leveraging on the reports of geochemical observations of the north central and southwestern basement complex, as well as $\mathrm{Pb}-\mathrm{Zn}$ deposits in southern Benue trough [14,18], we attempted to work out the dominant source regions in different parts of the Anambra Basin during the late Campanian to early Maastrichtian time.

Three of the factors controlling element associations, which were identified [18], proved to be quite useful in this study. These are:

a) An iron-oxide/hydroxide and ilmenite factor, which explains the low to moderate positive covariation between $\mathrm{Fe}$ and $\mathrm{Cu}$, $\mathrm{Cr}, \mathrm{Mo}, \mathrm{V}, \mathrm{Zn}, \mathrm{Co}, \mathrm{Sn}$, and Ti. The presence of ilmenite allows for a positive covariance between $\mathrm{Fe}$ and $\mathrm{Ti}$ or $\mathrm{Sn}$;

b) A mafic factor, which explains the positive covariation between $\mathrm{Fe}, \mathrm{Mn}$, and $\mathrm{Mg}$ due to the presence of ferromagnesian minerals such as olivine, pyroxene, hornblende, and biotite;

c) A coltan factor. Coltan abundance covaries positively with $\mathrm{Ta}$, $\mathrm{Nb}, \mathrm{Ti}, \mathrm{Sn}$, and $\mathrm{W}$.

\section{Mamu Formation}

On the western margin, the outcropping units show a broad $\mathrm{Pb}$ $\mathrm{Zn}$ covariation (Figure 8a-c), as well as an enrichment of $\mathrm{Pb}$ over $\mathrm{Zn}$ $(\mathrm{Pb} / \mathrm{Zn}>1)$ (Appendix 1c). There is a moderate influence from the Feoxide/hydroxide factor, which is observed only in the more proximal marsh unit as well as a strong to moderate coltan influence for Sn and $\mathrm{W}$ as shown by the positive Sn and W covariation with $\mathrm{Nb}$, Ta and $\mathrm{Ti}$ (Figure $8 \mathrm{a}-\mathrm{c}$ ). The $\mathrm{Sn}$ vs. $\mathrm{Pb}$ and $\mathrm{W}$ vs. $\mathrm{Pb}$ show a broad distribution in the bay unit, whereas a moderate positive covariation is observed in the central basin and marsh units (Figure 8a-c).

On the eastern margin, a weak positive $\mathrm{Pb}-\mathrm{Zn}$ covariation exists with $\mathrm{Pb} / \mathrm{Zn}<1$. In addition, there is a strong influence from the mafic factor as well as a minimal influence from the Fe-oxide/hydroxide/ ilmenite factor. The absence of $\mathrm{Sn}$ and $\mathrm{W}$ data prevents a discussion of the coltan factor. However, a moderately positive $\mathrm{Pb}$ vs. $\mathrm{Nb}$ covariation (Figure 8d) suggests some potential influence by the coltan factor. There is a coltan source, which exerts a minor influence on the distribution of Ti, Sn, and W in samples from the Owan-1 well (Figure $8 \mathrm{e})$. By contrast, the distributions of Sn and W are strongly controlled by the ilmenite factor as shown by the strong positive covariation of $\mathrm{Ti}$ with $\mathrm{Sn}, \mathrm{Fe}$ and W (Figure 8e). There is also a moderate influence from a mafic source as well as a good $\mathrm{Pb}-\mathrm{Zn}$ covariation $(\mathrm{Pb} / \mathrm{Zn}<1)$. In the Amansiodo- 1 well, there is a moderate mafic factor influence, a broad $\mathrm{Pb}-\mathrm{Zn}$ covariation $(\mathrm{Pb} / \mathrm{Zn}<1)$, as well as a strong Fe-oxide/ hydroxide/ilmenite factor (Figure 8e). In contrast to the sediments from the Owan-1 well wherein a moderate positive covariation of $\mathrm{Pb}$ vs. $\mathrm{Sn}$ is observed, the sediments from the Amansiodo-1 well show a broad $\mathrm{Pb}$ vs. Sn covariation as well as a moderate positive coltan influence for Ti and Sn (Figure 9a). Furthermore, in the Owan-1 well there is broad $\mathrm{W}$ vs. $\mathrm{Pb}$ covariation as well as good $\mathrm{W}$ vs. $\mathrm{Zn}$ 
a Marsh (Western Margin)

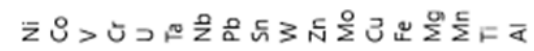

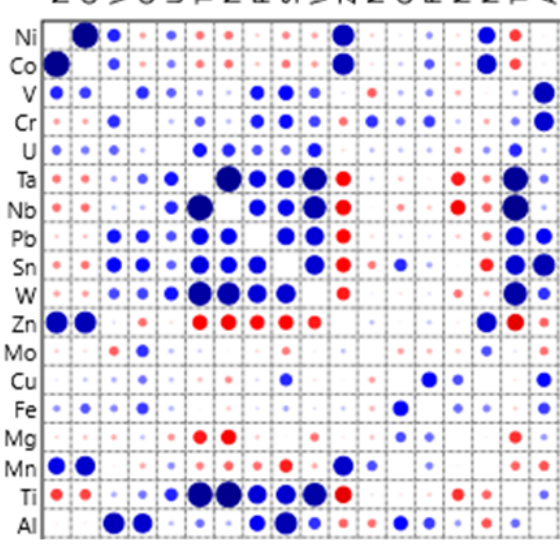

C Central basin (Western Margin)

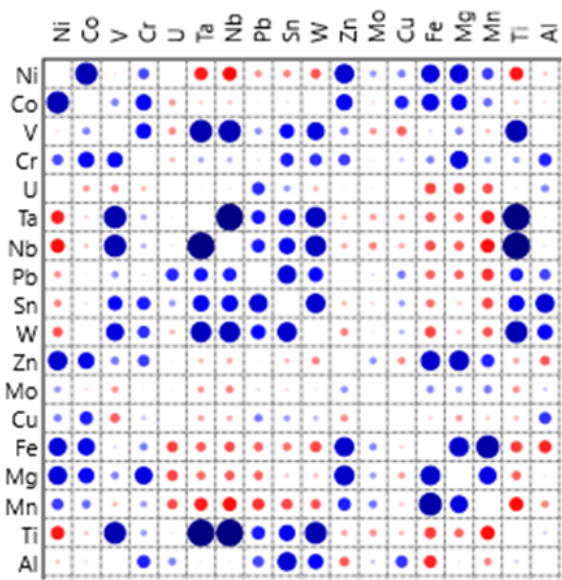

b Bay (Western Margin)

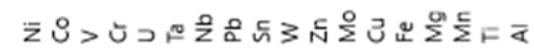

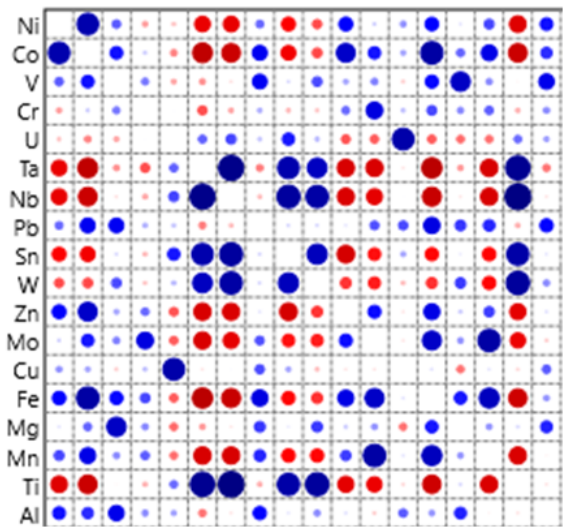

d Eastern margin (Odoma et al., 2015)

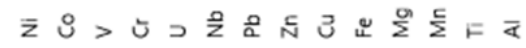

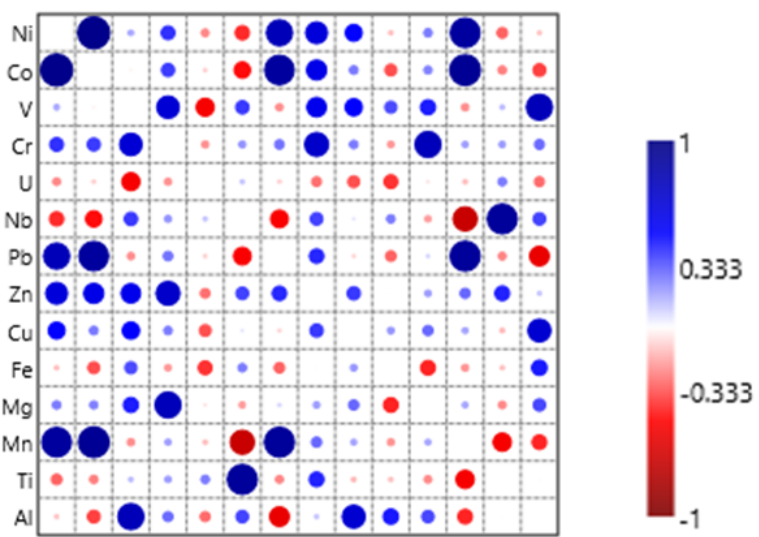

Figure 8: Correlation matrix for major and element abundances in sediments of the Mamu Formation on the western and eastern margins as well as the Owan-1 well.

covariation (Figure 8e), whereas the Amansiodo-1 well there is a good positive $\mathrm{W}$ vs. $\mathrm{Pb}$ covariation as well as a moderate positive $\mathrm{W}$ vs. $\mathrm{Zn}$ covariation (Figure 9a).

The $\mathrm{Pb}$ vs. $\mathrm{Zn}$ shows a poor covariation in sediments from the Idah-1well $(\mathrm{Pb} / \mathrm{Zn}>1)$, which becomes moderate in the Nzam-1 well $(\mathrm{Pb} / \mathrm{Zn}>1)$ (Figure $8 \mathrm{~b}-\mathrm{c}$ ). The influence of a coltan source for $\mathrm{Sn}$ and $\mathrm{W}$ improves from being weak in the Idah-1 well samples to moderate in the Nzam-1 well samples (Figure 8b-c). In addition, the influence of the mafic factor as well as the Fe-oxide/hydroxide factor is moderate in samples from these wells (Figure 8b-c).

\section{Awgu Group}

As observed earlier, this unit exhibits strong spatial geochemical variability. In sediments from the Amansiodo-1 well, the Fe-oxide/ hydroxide/ilmenite influence is minimal to non-existent (Figure $9 \mathrm{~d}$ ). There is also a strong mafic component as well as good positive $\mathrm{Pb}-\mathrm{Zn}$ covariation (Figure $9 \mathrm{~d}$ ) (median $\mathrm{Pb} / \mathrm{Zn}=0.23$ ). Conversely, the sediments from Akukwa-II well show a moderate positive $\mathrm{Pb}$ $\mathrm{Zn}$ covariation (median $\mathrm{Pb} / \mathrm{Zn}=0.17$ ), as well as a fair to strong influence from the mafic and Fe-oxide/hydroxide/ilmenite factors (Figure 9e). Furthermore, whereas the sediments from the Akukwa-
II well show a strong positive covariation of Ta with $\mathrm{Sn}$ as well as a strong negative covariation of $\mathrm{W}$ with Ta (Figure 9e), the sediments from the Amansiodo-1 well show the opposite. This is illustrated by the moderate covariation of $\mathrm{Ta}$ with $\mathrm{W}$ as well as a strong negative covariation of Sn with Ta (Figure 9d).

\section{Eze-Aku Group}

In the Eze-Aku Group, the influence of the coltan, mafic, as well as the Fe-oxide/hydroxide components are strong (Figure 9f). $\mathrm{Sn}$ moderately covaries positively with $\mathrm{Nb}, \mathrm{Ta}$, and $\mathrm{Ti}$, whereas $\mathrm{W}$ shows a broad to moderately negative covariation with $\mathrm{Nb}$, Ta and $\mathrm{Ti}$ (Figure 9f). There is a good positive $\mathrm{Pb}-\mathrm{Zn}$ covariation (median $\mathrm{Pb} /$ $\mathrm{Zn}=0.22$ ). In general, the pre-Santonian units show a stronger mafic influence as well as a stronger $\mathrm{Pb}-\mathrm{Zn}$ covariation, which is a function of the composition of the source rocks (section 5.2).

\section{Differentiation of Provenance Regions}

\section{Pre-Santonian Units}

Based on field observations, petrographic studies and paleocurrent measurements, earlier studies favoured the granites, gneisses and metasediments in the eastern highlands and southwestern basement 
a Amansiodo-1 well (Mamu Fm.)

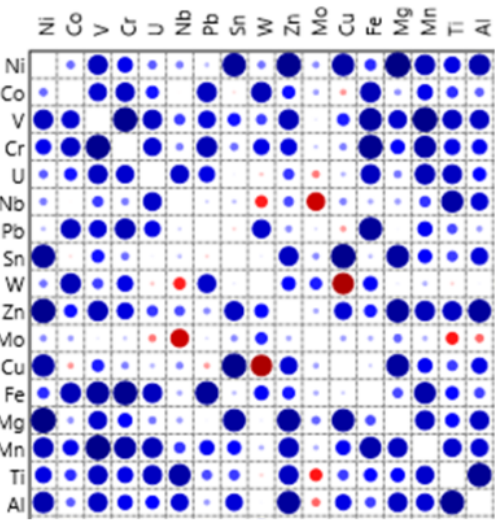

\section{d Amansiodo-1 well (Awgu Gp.)}

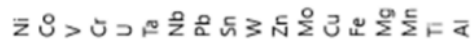

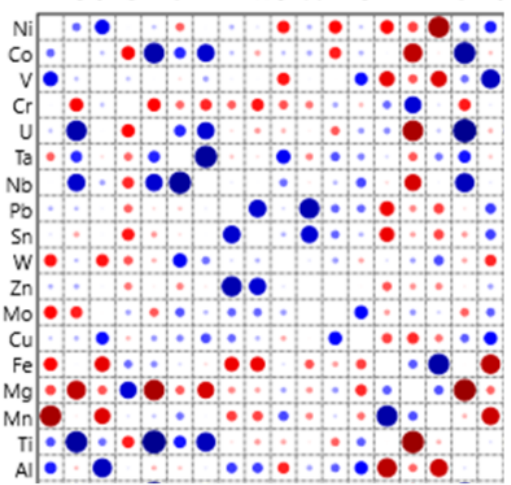

b

Nzam-1 well (Mamu Fm.)

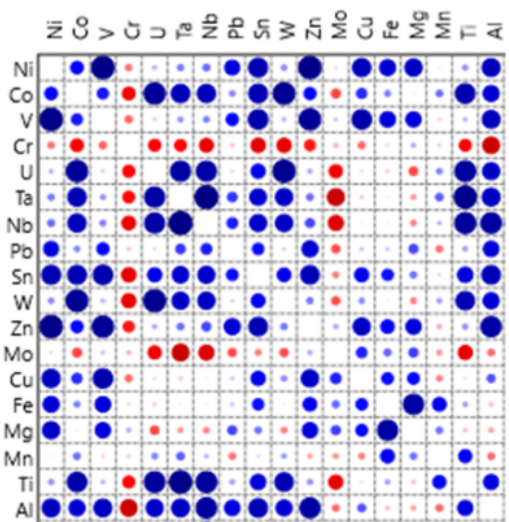

e Akukwa-ll well (Awgu Gp.)

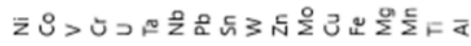

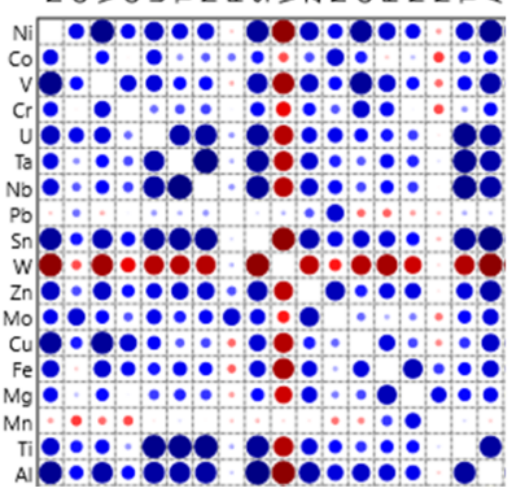

C Idah-1 well(Mamu Fm.)

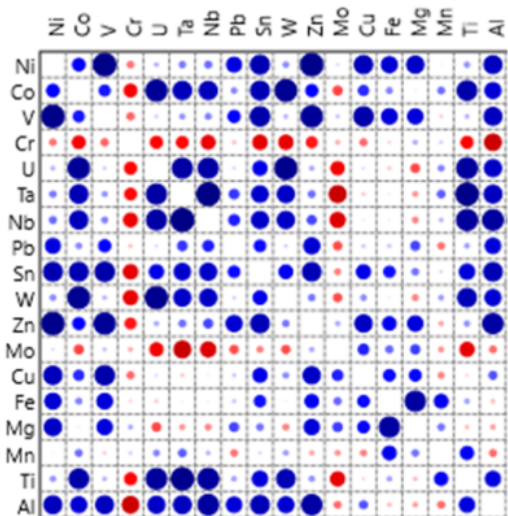

f Akukwa-ll well (Eze-Aku Gp.)

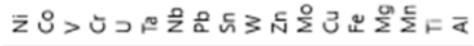

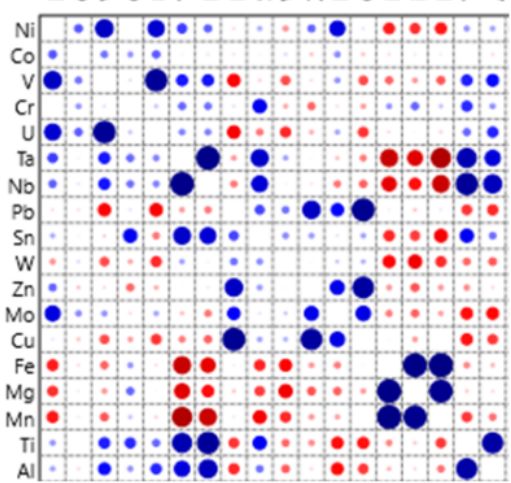

Figure 9: Correlation matrix for major and element abundances in sediments of the Mamu Formation and pre-Santonian units.

complex of Nigeria (Figure 2) $[5,7,9,46]$ as the provenance sources for the pre-Santonian units. The identification of a dominant mafic provenance for the Eze-Aku unit from our data (Figure 7a, c, e), which is strengthened by the strong mafic factor influence as illustrated by the strong positive covariation between Fe vs. $\mathrm{Mg}$, Fe vs. Mn as well as negative covariations of $\mathrm{Fe}$ vs. $\mathrm{Pb}$ and $\mathrm{Fe}$ vs. $\mathrm{Sn}$ (Figure $9 \mathrm{f}$ ) is quite an interesting find as this has only been advanced for the Asu-River Group [7]. The basement complex in the eastern highlands have been adduced to be the provenance for the Awgu and Eze-Aku groups in the eastern segment of the Anambra Basin [7,34]. However, we hypothesize a significant detrital contribution from the mineralized biotite granites as well the basement complex rocks of north central Nigeria (Figure 10a-b) due to the $\mathrm{Nb}$, Ta and $\mathrm{W}$ that are above the respective UCC as well as Sn (Appendix 1a-b, Figures 4c and 5c). A strong detrital contribution from north central Nigeria is adduced to be responsible for the distinct geochemical character observed in the sediments from Amansiodo-1 well in comparison to the Akukwa-II well. This is illustrated by the more felsic character or the sediments, higher degree of chemical alteration, higher Th, U, Nb, Ta, Sn (Figures $4 c$ and $5 c$, Appendix 1a-b), higher enrichment of $\mathrm{Nb}$ over Ta [16], as well as inference from the $\mathrm{Nb} / \mathrm{W}$ vs. $\mathrm{Nb} / \mathrm{Ta}$ bivariate plot (Figure 10a). Conversely, the sediments from Akukwa-II well, which show a higher W (Figure $5 \mathrm{c}$ ) as well as the strong negative to broad Ta vs. $\mathrm{W}$ covariation (Figure 9e-f) strongly suggests a large proportion of detrital contribution from the eastern highlands (Figure 10a-b) whose pegmatites are enriched in $\mathrm{W}$, but barren with respect to $\mathrm{Sn}, \mathrm{Ta}$ and $\mathrm{Nb}[55,56]$.

Furthermore, we hypothesize a spatio-temporal variation in detrital contribution from the various lithostratigraphic units that make up the eastern highlands and north central Nigeria. Detrital contribution was more from mafic rocks in the latest Cenomanian to early Turonian, whereas from middle Turonian to Coniacian the detrital contribution was more from felsic sources (Figure 7a-f). This is consistent with the findings [7].

\section{Mamu Formation}

From the geochemical characteristics highlighted above, it is hypothesized that the Mamu Formation is sourced from basement complex rocks as well as recycled pre-Santonian strata. In addition, three broad provenance regions can be distinguished: a Northern provenance, Western provenance, and an Eastern provenance (Figure 11).

\section{Western Provenance Region}

This region comprises the southwestern basement complex rocks as well as pre-Santonian units, relics of which exist as inliers within the basement complex rocks (Figure 11). In general, this provenance region is characterized by a strong coltan factor controlling the enrichment 


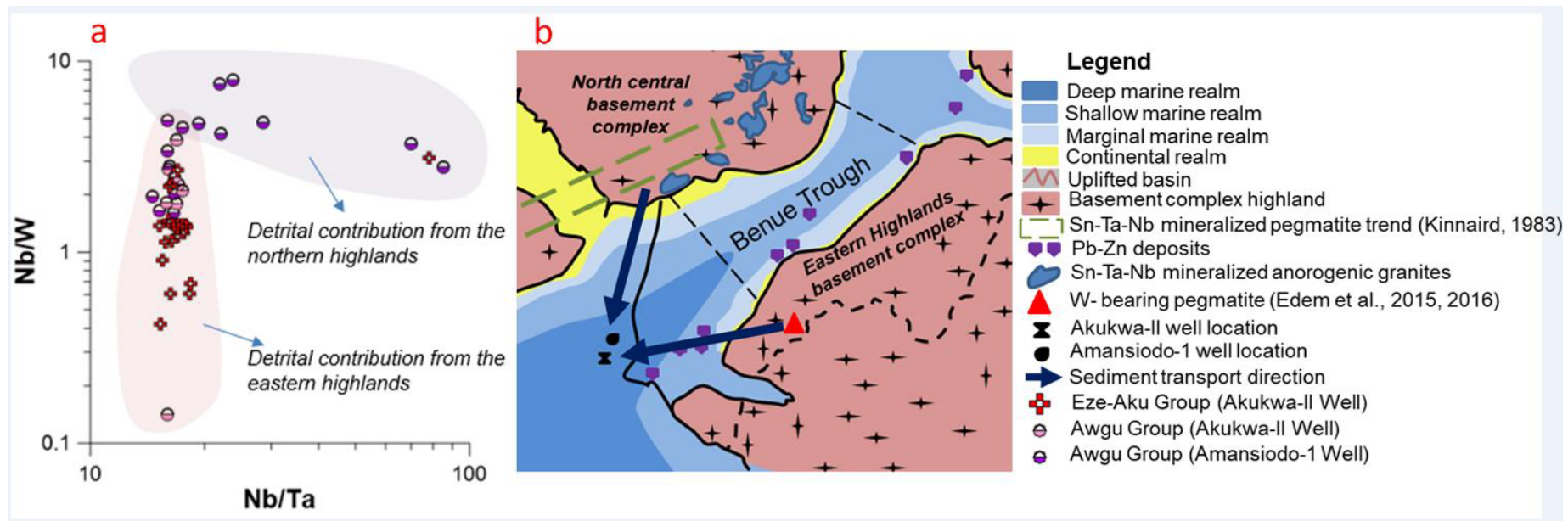

Figure 10: $\mathrm{a}, \mathrm{Nb} / \mathrm{W}$ vs. $\mathrm{Nb} / \mathrm{Ta}$ binary plot differentiating provenance regions of pre-Santonian units. b, conceptual early Turonian paleogeographic model showing contribution from eastern and northcentral highlands.

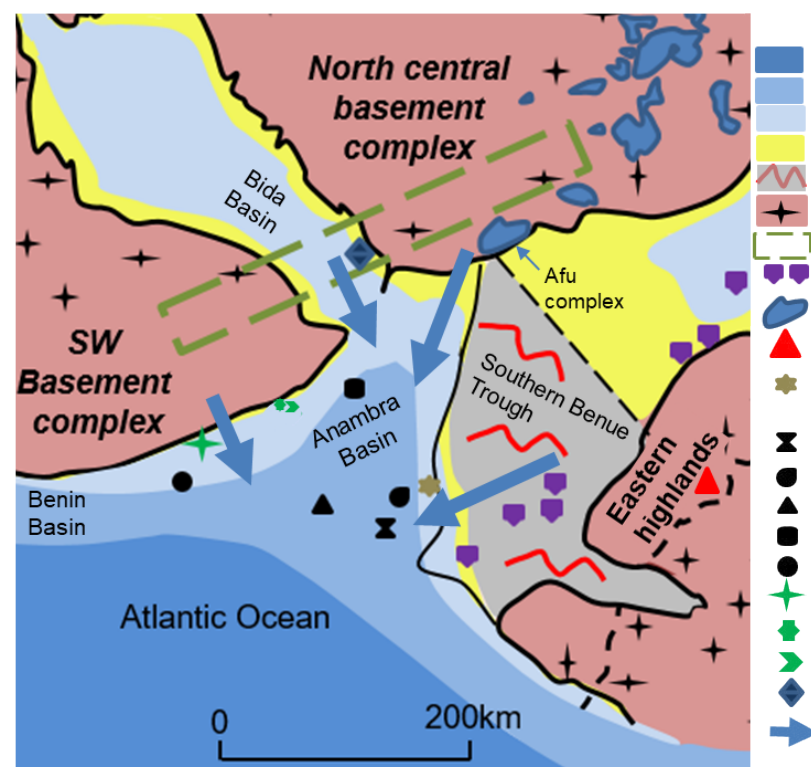

\section{Legend}

Deep marine realm

Shallow marine realm

Marginal marine realm

Continental realm

Uplifted basin

Basement complex highland

$\mathrm{Sn}-\mathrm{Ta}-\mathrm{Nb}$ mineralized pegmatite trend (Kinnaird, 1983)

$\mathrm{Pb}-\mathrm{Zn}$ deposits

$\mathrm{Sn}-\mathrm{Ta}-\mathrm{Nb}$ mineralized anorogenic granites

W- bearing pegmatite (Edem et al., 2015, 2016)

- Outcrop location on the eastern margin

(Odoma et al., 2015)

I Akukwa-ll well location

- Amansiodo-1 well location

- Nzam-1 well location

- Idah-1 well location

- Owan-1 well location

+ Outcrop location (Marsh samples)

- Outcrop location (Central basin samples)

- Outcrop location (Bay samples)

- Patti Formation (Nton and Adamolekun, 2016)

Sediment transport direction

Figure 11: Provenance regions of the Anambra Basin

of $\mathrm{Nb}, \mathrm{Ta}, \mathrm{Sn}, \mathrm{W}$ (and Pb to a certain extent), high levels of Th, U, Ta, $\mathrm{Nb}, \mathrm{Sn}, \mathrm{Pb}$ as well has higher $\mathrm{Pb} / \mathrm{Zn}(\mathrm{Pb} / \mathrm{Zn}>1)$ when compared to the eastern province. Leveraging on published data [14,57], the main difference between the western provenance terrain from those of the southwestern portion of the north central province is the much higher $\mathrm{Pb}$ abundance, which is consistent with the findings of a previous study [14]. There is some variability in the element pattern of the western provenance, as a portion of it is not strongly influenced by the coltan factor as shown by much lower $\mathrm{Pb}, \mathrm{Sn}, \mathrm{Nb}, \mathrm{Ta}$, and $\mathrm{Y}$ concentrations, lower $\mathrm{Pb} / \mathrm{Zn}(\mathrm{Pb} / \mathrm{Zn}<1)$, as well as much higher $\mathrm{W}$ recorded from sediments of the Owan-1 well. The very weak positive covariation for $\mathrm{Nb}$ vs. Ti and $\mathrm{Nb}$ vs. $\mathrm{Sn}$ illustrate further evidence for this (Figure 8e). In addition, the good positive covariation between Ti vs. Sn suggests an alternative source for Ti instead of coltan, which is suspected to be ilmenite [14] as well as minerals in the ilmenite-geikielite (MgTiO3) and ilmenite-pyrophanite (MnTiO3) solid solution series due to good to moderate positive covariation of Ti vs. Fe, $\mathrm{Mn}$, and $\mathrm{Mg}$ (Figure 8e).
These Titanium bearing minerals have been documented to occur in the southwestern basement complex rocks [58].

\section{Eastern Provenance Region}

The eastern provenance region (Figure 8) comprises the preSantonian strata from the Southern Benue Trough as well as the basement complex rocks from the eastern highlands (Figure 11). In general, higher $\mathrm{Zn}$, TTE, $\mathrm{Cu}, \mathrm{Mo}$, and major element (excluding $\mathrm{Al}$ and $\mathrm{Ti}$ ) concentrations, much lower $\mathrm{Pb} / \mathrm{Zn}$ ratios $(\mathrm{Pb} / \mathrm{Zn}<1)$, a strong $\mathrm{W}$ enrichment [55-56], as well as lower levels of $\mathrm{Nb}, \mathrm{Ta}$ and $\mathrm{Sn}$ in comparison with the northern and western provenance regions characterize the eastern provenance. In addition, there exists a good positive $\mathrm{Pb}$ vs. $\mathrm{Zn}$ covariation, as well as a less strong coltan influence for $\mathrm{Sn}$, which in contrast with the western provenance region shows a broad or strong negative covariation with $\mathrm{W}$. The much higher major element concentration, which is characteristic of this provenance region is a function of the strong mafic influence on the sediments. 


\section{Northern Provenance Region}

The anorogenic biotite granites as well as the basement complex rocks in the north central provenance region is hypothesized to have contributed detritus for sediments in the northern segment of the basin, sediments close to the western margin, the area around the Amansiodo-1 well, as well as intervals within the Idah-1 well. We came to this conclusion because some intervals in the Idah-1 well have $\mathrm{W}$ concentration above $23.2 \mathrm{ppm}$ (Figure 12a), which is the highest $\mathrm{W}$ concentration reported for stream sediments draining the southwestern portion of the north central basement complex [14]. High levels of W concentration have been reported for the biotite granites in the Afu complex, north central Nigeria [18]. In addition, these units show high levels of $\mathrm{Nb}, \mathrm{Y}, \mathrm{Th}, \mathrm{Zn}, \mathrm{Ti}$, and $\mathrm{U}$, higher enrichment of $\mathrm{Nb}$ over $\mathrm{Ta}$ [17], as well as low $\mathrm{V}$ and $\mathrm{Pb} / \mathrm{Zn}(\mathrm{Pb} / \mathrm{Zn}<1)$.

\section{Mixing of Provenance Regions}

Our published data on the outcropping units on the western margin posit that the marsh samples are the most proximal units of the dark mudstone lithofacies [9]. This implies that the geochemistry of this unit is the least influenced by mixing from the northern and eastern provenance regions. The bay samples are the most affected by mixing as illustrated by higher median concentrations of HFSE as well as $\mathrm{Pb}, \mathrm{Sn}$, and $\mathrm{W}$ (Figure 12a-d) when compared with the marsh and central basin samples. This is due to contribution from multiple source regions as depicted by the broad distributions of $\mathrm{Pb}$ vs. $\mathrm{Sn}$ and $\mathrm{W}$ vs. $\mathrm{Pb}$ (Figure $8 \mathrm{~b}$ ), the fractionation (concentration gradient) of $\mathrm{Pb}, \mathrm{Nb}, \mathrm{W}$, and $\mathrm{Sn}$ between the outcropping Patti Formation (Bida Basin), sediments from the Idah-1 and Owan-1 wells, as well as the outcropping Mamu Formation on the western margin (Figure 12a-d).

The sediments of the more centrally located Idah-1 and Nzam1 wells also show clear evidence of mixing of source terrains. This is clearly illustrated by the $\mathrm{Pb} / \mathrm{Nb}$ vs. $\mathrm{Pb} / \mathrm{Sn}$ as well as the $\mathrm{Pb}$ vs. $\mathrm{Sn}$ bivariate plots (Figure 13a-b). It is hypothesized that the high $\mathrm{Pb}$ values associated with sediments from the Idah-1 well is due to mixing of detritus from all three-provenance regions, as concentrations well above the lower thresholds for $\mathrm{Pb}$ and $\mathrm{Zn}$ (100 ppm and $200 \mathrm{ppm}$ respectively) in $\mathrm{Pb}-\mathrm{Zn}$ mineralized regions of the eastern provenance $[15,16]$ abound. In addition, the high levels of $\mathrm{W}$ recorded in some intervals in the Idah-1 well as well as the Amansiodo-1 well (Appendix 1a) are within the range reported for the $\mathrm{Sn}-\mathrm{Nb}$ - Ta mineralized biotite granites of the Afu complex [18] located in the Northcentral provenance region.

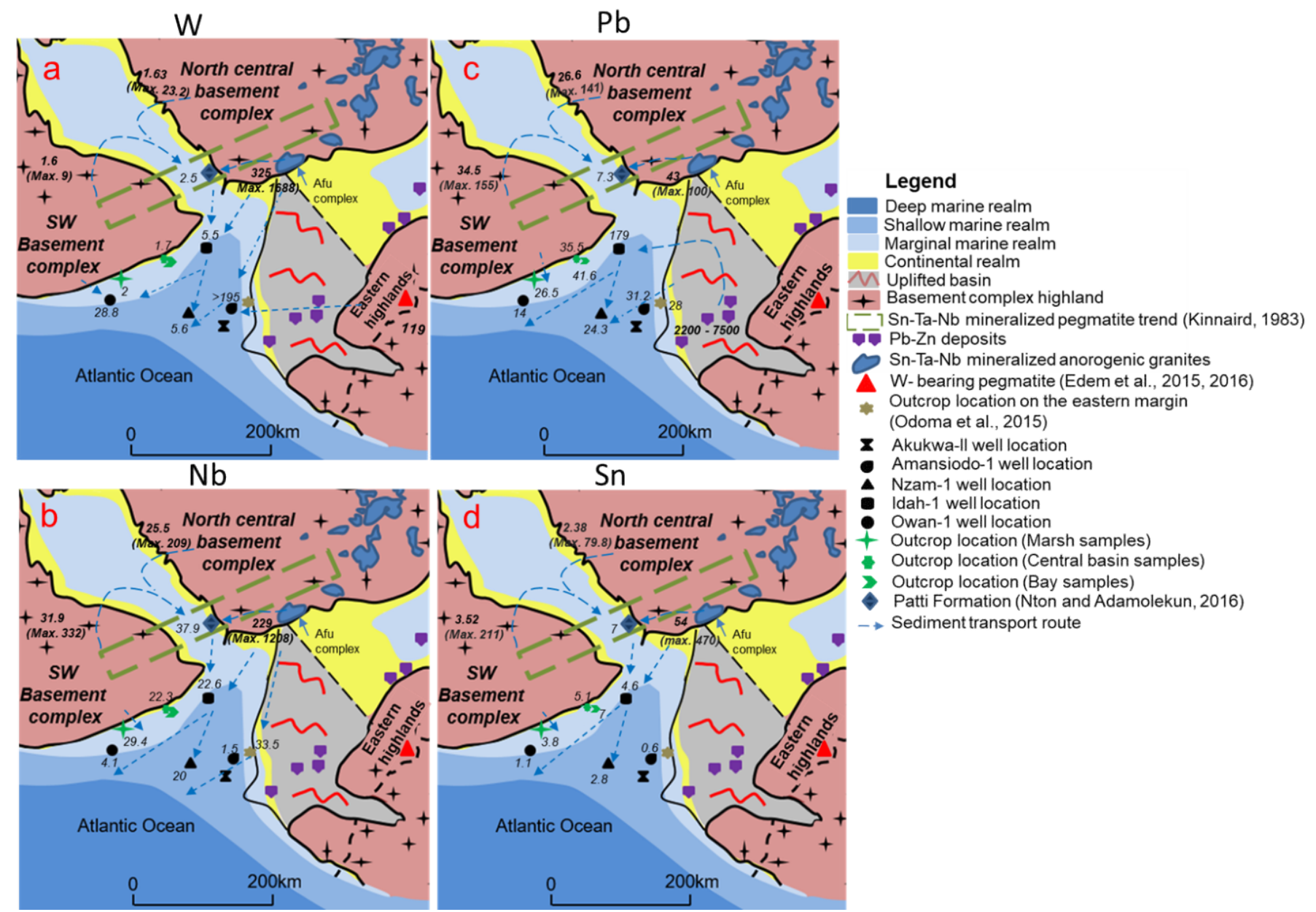

Figure 12: Evidence of mixing of provenance regions deduced from median concentrations of $\mathrm{Pb}, \mathrm{W}, \mathrm{Nb}$, and Sn from spatial units of the Mamu and Patti formations. 

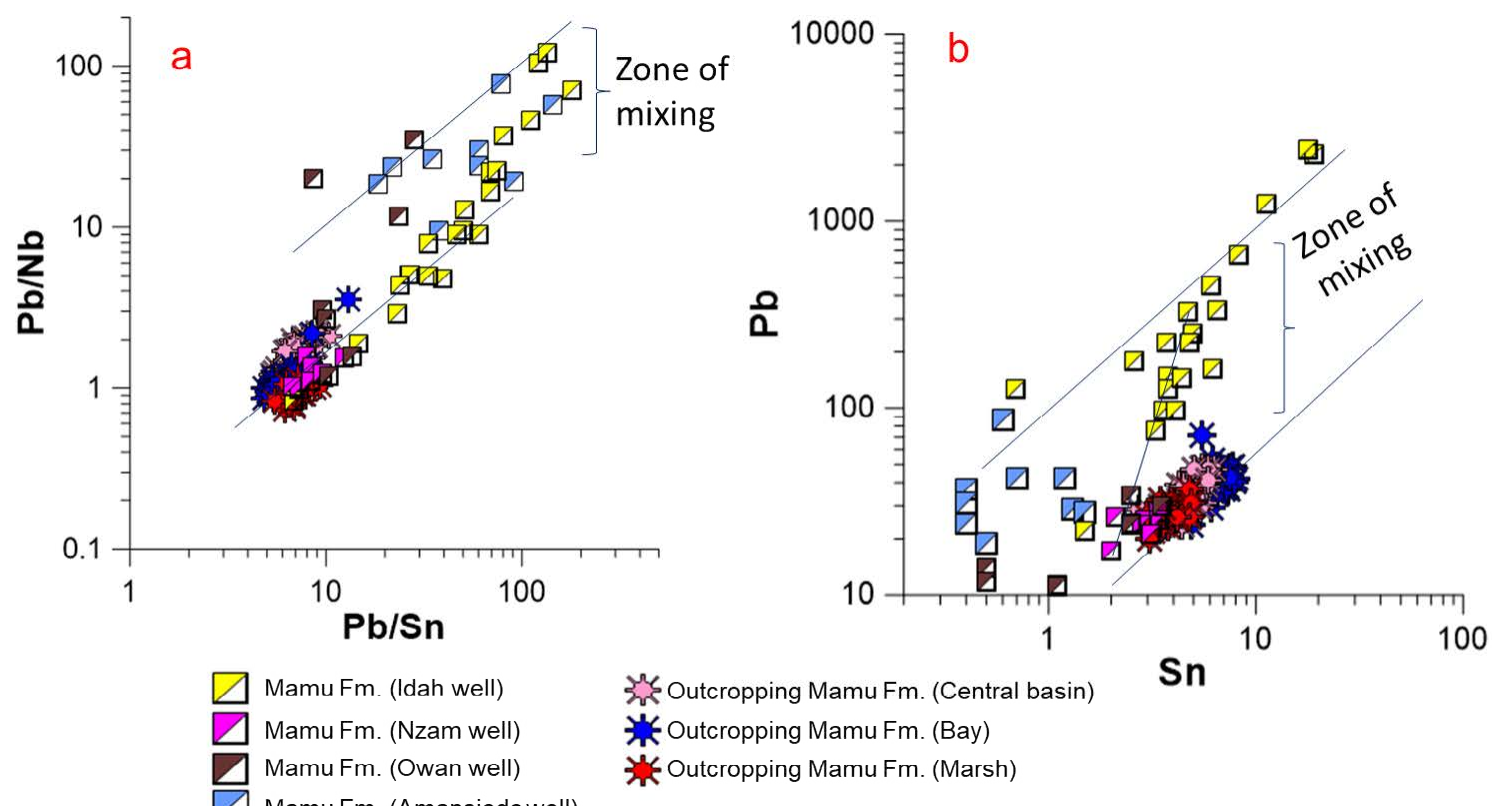

Figure 13: $\mathrm{Pb} / \mathrm{Nb}$ vs. $\mathrm{Pb} / \mathrm{Sn}(\mathrm{a})$ and $\mathrm{Pb}$ vs. $\mathrm{Sn}(\mathrm{b})$ binary plots showing further evidence of mixing of source regions.

\section{Conclusion}

This study reports the following findings:

- The pre-Santonian units are sourced from compositionally variable basement complex rocks, ranging from felsic to mafic in composition.

- There is evidence for spatio-temporal variability in the detrital contribution from the basement complex rocks. Detrital contribution was more from mafic rocks in the latest Cenomanian to early Turonian, whereas from middle Turonian to Coniacian the detrital contribution shifted to more felsic sources.

- The provenance of the Mamu Formation is from felsic source rocks comprising of basement complex rocks as well as recycled pre-Santonian rocks. The significant detrital contribution from basement complex rocks provides clear insight regarding to the origin of large sand volumes in the post-Santonian Anambra basin. These hitherto could not be accounted for, due to the predominance of argillaceous and carbonate rocks in the Southern Benue Trough

- Three provenance regions comprising the northern, western, eastern sectors contributed detritus during the CampanoMaastrichtian with evidence of mixing of provenance sources.

- The Mamu Formation shows evidence of secondary Pb, Sn, and $\mathrm{W}$ accumulation.

\section{Acknowledgement}

This research received support from University of Benin Research and Publications Committee, the Fulbright Commission (15160892), the Niger Delta Development Commission, Nigeria (NDDC/ DEHSS/2015PGFS/EDS/011), and DAAD (ST32 - PKZ: 91559388).
Julius Imarhiagbe and Reuben Okoliko assisted with fieldwork and sampling of cuttings and core at the Nigerian Geological Survey Agency respectively. In addition, the first author wishes to acknowledge the motivation, guidance and instruction provided by Prof. W.O. Emofurieta and Mr. Sam Coker during the early phase of this research (Table 1a-1c).

\section{References}

1. Ladipo KO (1986) Tidal shelf depositional model for the Ajali Sandstone, Anambra Basin, Southern Nigeria. J Afr Earth Sci 5: 177-185.

2. Ladipo KO (1988) Paleogeography, sedimentation and tectonics of the Upper Cretaceous Anambra Basin, Southeastern Nigeria. J Afr Earth Sci 7: 865-871.

3. Amajor LC (1987) Paleocurrent, petrography and provenance analyses of the Ajali sandstone (upper cretaceous), southeastern Benue Trough, Nigeria. Sediment Geol 54: 47-60.

4. Obi GC, Okogbue CO (2004) Sedimentary response to tectonism in the CampanianMaastrichtian succession, Anambra Basin, Southeastern Nigeria. J Afr Earth Sci 38:99-108.

5. Hoque M (1977) Petrographic differentiation of tectonically controlled Cretaceous sedimentary cycles, southeastern Nigeria. Sediment Geol 17: 235-245.

6. Edegbai AJ, Schwark L, Oboh-Ikuenobe FE (2019a) A review of the latest Cenomanian to Maastrichtian geological evolution of Nigeria and its stratigraphic and paleogeographic implications. J Afr Earth Sci 150: 823-837.

7. Odigi MI (2007) Facies architecture and sequence stratigraphy of Cretaceous formations, southeastern Benue Trough, Nigeria. Unpublished Ph.D thesis, University of Portharcourt, Nigeria, p: 288.

8. Tijani MN, Nton ME, Kitagawa R (2010) Textural and geochemical characteristics of the Ajali Sandstone, Anambra basin, SE Nigeria: Implication for its provenance. Comptes Rendus Geoscience 342: 136-150.

9. Edegbai AJ, Schwark L, Oboh-Ikuenobe F.E (2019b) Campano-Maastrichtian paleoenvironment, paleotectonics and sediment provenance of Western Anambra Basin, Nigeria: Multi-proxy evidences from the Mamu Formation. J Afr Earth Sci 156: 203-239.

10. Petters SW (1978) Stratigraphic evolution of the Benue Trough and its implications for the Upper Cretaceous paleogeography of West Africa. J Geol 86: 311-322. 
Edegbai Aitalokhai Joel (2020) Differentiation of Sediment Source Regions in the Southern Benue Trough and Anambra Basin, Nigeria: Insights from Geochemistry of Upper Cretaceous Strata

11. Bonne KPM (2014) Reconstruction of the evolution of the Niger river and implications for sediment supply to the equatorial Atlantic margin of Africa during the cretaceous and the Cenozoic. Geol Soc London Spl Publ 386: 327-349.

12. Markwick PJ (2018) Palaeogeography in exploration. Geol Mag 1-42.

13. Odoma AN, Obaje NG, Omada JI, Idakwo SO, Erbacher J (2015) Mineralogical, chemical composition and distribution of rare earth elements in clay-rich sediments from Southeastern Nigeria. J Afr Earth Sci 102: 50-60.

14. Lapworth DJ, Knights KV, Key RM, Johnson CC, Ayoade E, Adekanmi MA, Arisekola TM, Okunlola OA, Backman B, Eklund M, Everett PA, Lister RT, Ridgway J, Watts MJ, Kemp SJ, Pitfield PEJ (2012) Geochemical mapping using stream sediments in west-central Nigeria: implications for environmental studies and mineral exploration in West Africa. Applied Geochemistry 27, 1035-1052.

15. Olade MA, Van de Kraats AH, Ukpong EE (1978) Effects of environmental parameters on metal dispersion patterns in stream sediments from the lead-zinc belt. Benue Trough, Nigeria. Geologie en Mijnb 58: 341-351.

16. Olade MA (1987) Dispersion of Cadmium, Lead and Zinc in Soils and Sediments of a Humid Tropical Ecosystem in Nigeria. In: T. C. Hutchinson and K. M. Meema (Eds.), Lead, Mercury, Cadmium and Arsenic in the Environment. John Wiley \& Sons Ltd, New York, Scope 31: 303-313.

17. Kinnaird JA (1984) Contrasting styles of Sn-Nb-Ta-Zn mineralization in Nigeria. J Afr Earth Sci 2: 81-90.

18. Imeokparia EG (1982a) Abundance and distribution of tungsten in the Afu Younger Granite complex, central Nigeria. J of Geochem Expl 17: 93-108.

19. Benkhelil J (1989) The origin and evolution of the Cretaceous Benue Trough, Nigeria. J Afr Earth Sci 8: 251-282.

20. Nwajide CS (2013) Geology of Nigeria’s Sedimentary Basins. CSS Bookshop Ltd., Lagos, pg: 565

21. Fairhead JD (1988) Mesozoic plate tectonic reconstructions of the central South Atlantic Ocean: the role of the West and Central African rift system. In: Scotese, C.R., Sager, W.W. (Eds.), Mesozoic and Cenozoic Plate Reconstructions. Tectonophysics 155: 181-191.

22. Fairhead JD, Green CM (1989) Controls on rifting in Africa and the regional tectonic model for the Nigerian and East Niger rift basins. J Afr Earth Sci 8: 231-249.

23. Fairhead JD, Binks RM (1991) Differential opening of the central and south Atlantic oceans and the opening of the West African Rift System. Tectonophysics 187: 191-203.

24. Fairhead JD, Green CM, Masterton SM, Guiraud R (2013) The role that plate tectonics, inferred stress changes and stratigraphic unconformities have on the evolution of the West and Central African Rift System and the Atlantic continental margins. Tectonophysics 594: 118-127.

25. Moulin M, Aslanian D, Unternehr P (2010) A new starting point for the south and equatorial Atlantic Ocean. Earth Sci Rev 98: 1-37.

26. Adeleye DR (1975) Nigerian late Cretaceous stratigraphy and palaeogeography. Am Assoc Pet Geol (AAPG) Bull. 59: 2302-2313.

27. Reyment RA, Dingle RV (1987) Palaeogeography of Africa during the Cretaceous period. Palaeogeogr. Palaeoclimatol Palaeoecol 59: 93-116.

28. Petters SW, Ekweozor CM (1982) Petroleum Geology of Benue Trough and Southeastern Chad Basin, Nigeria. AAPG (Am Assoc Pet Geol) Bull. 66: 1141-1149.

29. Gebhardt H (1999) Cenomanian to Coniacian ostracods from the Nkalagu area (SE Nigeria): biostratigraphy and palaeoecology. Paläontol Z 73: 77-98.

30. Banerjee I (1981) Storm lag and related facies of the bioclastic limestones of the EzeAku Formation (Turonian), Nigeria. Sed Geo 30: 133-147.

31. Umeji OP (1984) Ammonite palaeoecology of the Eze-Aku Formation, southeastern Nigeria. Nigerian Journal of Mining and Geology 21: 55-59.

32. Gebhardt H (1998) Benthic foraminifera from the Maastrichtian lower Mamu Formation near Leru (Southern Nigeria): paleoecology and paleogeographic significance. J Foraminifer Res 28: 76-89.

33. Kuhnt W, Herbin JP, Thurow J, Wiedmann J (1990) Distribution of Cenomanian-
Turonian Organic Facies in the Western Mediterranean and Along the Adjacent Atlantic Margin. In: Huc, A. Y. (Ed.): Deposition of Organic Facies. American Association of Petroleum Geologists, Studies in Geology 30: 133-160.

34. Igwe EO, Okoro AU (2016) Field and lithostratigraphic studies of the Eze-Aku Group in the Afikpo synclinorium, southern Benue Trough, Nigeria. J Afr Earth Sci 119: $38-51$.

35. Dim CIP, Okwara IC, Mode AW, Onuoha KM (2016) Lithofacies and environments of deposition within the middle-upper Cretaceous successions of southeastern Nigeria. Arabian J Geosci 9: 1-17.

36. Dim CIP, Onuoha KM, Okwara IC, Okonkwo IA, Ibemesi PO (2019) Facies analysis and depositional environment of the Campano - Maastrichtian coal bearing Mamu Formation in the Anambra Basin, Nigeria. J AfrEarth Sci 152.

37. Guiraud R, Bosworth W (1997) Senonian basin inversion and rejuvenation of rifting in Africa and Arabia. Synthesis and implications to plate-scale tectonics. Tectonophysics 282: 39-82.

38. Okoro AU, Igwe EO (2018a) Sequence stratigraphy and controls on sedimentation of the Upper Cretaceous in the Afikpo Sub-basin, southeastern Nigeria. Arabian Journal of Geosciences 11.

39. Okoro AU, Igwe EO (2018b) Lithostratigraphic characterization of the Upper Campanian - Maastrichtian succession in the Afikpo Sub-basin, southern Anambra Basin, Nigeria. J Afr Earth Sci 147: 178-189.

40. Akande SO, Mücke A (1993) Tectonic and sedimentation framework of the lower Benue Trough, southeastern Nigeria. J Afr Earth Sci 17: 445-456.

41. Zaborski PMP (1983) Campano-Maastrichtian ammonites, correlation and palaeogeography in Nigeria. J Afr Earth Sci 1: 59-63.

42. Cullers RL, Stone J (1991) Chemical and mineralogical comparison of the Pennsylvanian Fountain Formation, Colorado, U.S.A. (an uplifted continental block) to sedimentary rocks from other tectonic environments. Lithos 27: 115-131.

43. McLennan SM (2001) Relationships between the trace element composition of sedimentary rocks and upper continental crust. Geochem Geophys Geosyst 2. DOI: 542 10.1029/2000GC000109

44. Anderson DH, Hawkes HE (1958) Relative mobility of the common elements in weathering of some schist and granite areas. Geochim Cosmo 14: 204-210.

45. Nesbitt HW, Young GM (1982) Early Proterozoic climates and plate motions inferred from major element chemistry of lutites. Nature 299: 715-717.

46. Igwe EO (2017) Composition, provenance and tectonic setting of Eze-Aku Sandstone facies in the Afikpo Synclinorium, Southern Benue Trough, Nigeria. Environ Earth Sci 76: 1-12.

47. Hay W, Floegel S (2012) New thoughts about the Cretaceous climate and oceans. Earth Sci Rev 115: 262-272.

48. Bhatia MR, Crook KAW (1986) Trace element characteristics of greywackes and tectonic setting discrimination of sedimentary basins. Contrib Mineral Petrol 92: $181-193$

49. Wronkiewicz DJ, Condie KC (1990) Geochemistry and mineralogy of sediments from the Ventersdorp and Transvaal Supergroups, South Africa: Cratonic evolution during the early Proterozoic. Geochem Cosmochim Acta 54: 343-354.

50. McLennan SM, Taylor SR (1991) Sedimentary rocks and crustal evolution: tectonic setting and secular trends. J of Geology 99: 1-21.

51. Cullers RL (1995) The controls on the major- and trace-element evolution of shales, siltstones and sandstones of Ordovician to tertiary age in the Wet Mountains region, Colorado, U.S.A. Chem Geol 123: 107-131.

52. Cullers RL (2000) The geochemistry of shales, siltstones and sandstones of Pennsylvanian- Permian age, Colorado, U.S.A.: implications for provenance and metamorphic studies. Lithos 51: 181-203.

53. Potter PE, Maynard JB, Depetris PJ (2005) Mud and Mudstones: Introduction and Overview. Springer-Verlag, pg: 297

54. McLennan SM, Hemming S, McDaniel DK, Hanson GN (1993) Geochemica approaches to sedimentation, provenance, and tectonics. In: In: Johnsson MJ, Basu, A (Eds.), Processes Controlling the Composition of Clastic Sediments: Boulder, Colorado, vol. 284. Geological Society of America Special Paper, pg: 21-40 
Edegbai Aitalokhai Joel (2020) Differentiation of Sediment Source Regions in the Southern Benue Trough and Anambra Basin, Nigeria: Insights from Geochemistry of Upper Cretaceous Strata

55. Edem GO, Ekwueme BN, Ephraim BE (2015) Geochemical signatures and mineralization potentials of precambrian pegmatites of southern Obudu, Bamenda Massif, southeastern Nigeria. International Journal of Geophysics and Geochemistry 2: 53-67.

56. Edem GO, Ekwueme BN, Ephraim BE, Igonor EE (2016) Preliminary investigation of pegmatites in Obudu area, southeastern Nigeria, using stream sediments geochemistry. Global Journal of Pure and Applied Sciences 22: 167-175.
57. Nton ME, Adamolekun OJ (2016) Sedimentological and geochemical characteristics of outcrop sediments of Southern Bida Basin, central Nigeria: implications for provenance, paleoenvironment and tectonic history. Ife Journal of Science 18: 345369.

58. Mücke A, Woakes M (1986) Pyrophanite: a typical mineral in the Pan-African Province of Western and Central Nigeria. J Afr Earth Sci 5: 675-689.

\section{Citation:}

Edegbai Aitalokhai Joel, Schwark Lorenz (2020) Differentiation of Sediment Source Regions in the Southern Benue Trough and Anambra Basin, Nigeria: Insights from Geochemistry of Upper Cretaceous Strata. Geol Earth Mar Sci Volume 2(2): 1-37. 
Edegbai Aitalokhai Joel (2020) Differentiation of Sediment Source Regions in the Southern Benue Trough and Anambra Basin, Nigeria: Insights from Geochemistry of Upper Cretaceous Strata

Table 1a-1c: Summary table showing the results of elemental analysis as well as elemental ratios. Appendix 10

\begin{tabular}{|c|c|c|c|c|c|c|c|c|c|c|c|c|c|c|c|c|c|}
\hline $\mathrm{S} / \mathrm{N}$ & $\begin{array}{l}\text { Lithostratigraphic } \\
\text { Unit }\end{array}$ & Location & $\mathrm{Ca}$ & $\mathrm{Fe}$ & K & Mg & Mn & $\mathrm{Na}$ & $\mathbf{T i}$ & Al & $\mathrm{TiO}_{2}$ & $\mathbf{P b}$ & Sn & W & $\mathrm{Zn}$ & Mo & $\mathrm{Cu}$ \\
\hline U1 IA & \multirow{2}{*}{$\begin{array}{l}\text { Mamu } \\
\text { Formation }\end{array}$} & \multirow{3}{*}{$\begin{array}{l}\text { Western margin } \\
\quad \text { (Marsh } \\
\text { subenvironment) }\end{array}$} & 0.021 & 0.94 & 0.32 & 0.07 & 0.004 & 0.015 & 0.91 & 8.05 & 1.68 & 27.8 & 3.6 & 2.1 & 14 & 3 & 7.1 \\
\hline U1 1C & & & 0.014 & 0.57 & 0.26 & 0.05 & 0.003 & 0.015 & 0.83 & 6.83 & 1.58 & 21.9 & 3.2 & 1.7 & 14 & 2.6 & 8.7 \\
\hline U1 2A & & & 0.014 & 1.19 & 0.30 & 0.05 & 0.003 & 0.015 & 0.89 & 7.89 & 1.68 & 23.4 & 3.8 & 2 & 9 & 2.2 & 7.7 \\
\hline U1 2B & & & 0.014 & 0.72 & 0.23 & 0.04 & 0.003 & 0.015 & 0.80 & 6.46 & 1.48 & 26.5 & 3 & 1.7 & 18 & 0.9 & 4.6 \\
\hline U1 2C & & & 0.014 & 0.57 & 0.31 & 0.06 & 0.003 & 0.015 & 0.94 & 7.89 & 1.79 & 32.4 & 3.5 & 1.9 & 9 & 2.3 & 4.2 \\
\hline U1 3A & & & 0.014 & 1.09 & 0.32 & 0.06 & 0.004 & 0.015 & 0.93 & 7.73 & 1.75 & 25.6 & 3.7 & 2.2 & 15 & 1.1 & 6 \\
\hline U1 3B & & & 0.014 & 0.86 & 0.38 & 0.07 & 0.003 & 0.022 & 0.95 & 9.10 & 1.81 & 28.6 & 4.3 & 2.2 & 15 & 1.9 & 5.8 \\
\hline U1 5A & & & 0.021 & 0.80 & 0.36 & 0.07 & 0.004 & 0.022 & 0.90 & 11.70 & 1.63 & 29.1 & 4.1 & 2 & 15 & 2.5 & 6.5 \\
\hline U1 5B & & & 0.021 & 0.92 & 0.36 & 0.07 & 0.004 & 0.022 & 0.85 & 12.54 & 1.56 & 27.7 & 4 & 2 & 12 & 2 & 5.1 \\
\hline U1 6A & & & 0.021 & 0.87 & 0.37 & 0.07 & 0.003 & 0.015 & 0.87 & 11.75 & 1.60 & 25.6 & 4.1 & 2.2 & 13 & 1.1 & 6.6 \\
\hline U1 7A & & & 0.029 & 1.84 & 0.25 & 0.08 & 0.006 & 0.022 & 0.76 & 10.69 & 1.47 & 23.8 & 3.2 & 1.7 & 211 & 2.1 & 27.4 \\
\hline U1 7B & & & 0.014 & 0.60 & 0.27 & 0.07 & 0.004 & 0.015 & 0.87 & 9.84 & 1.60 & 25.9 & 3.7 & 1.9 & 83 & 1 & 11.3 \\
\hline U1 8A & & & 0.014 & 1.45 & 0.23 & 0.07 & 0.004 & 0.007 & 0.78 & 10.50 & 1.36 & 23.9 & 3.6 & 1.5 & 139 & 0.8 & 15.6 \\
\hline U1 8B & & & 0.057 & 1.27 & 0.25 & 0.08 & 0.008 & 0.022 & 0.87 & 7.62 & 1.64 & 26.2 & 3.5 & 2 & 132 & 1.4 & 10.6 \\
\hline U1 8C & & & 0.014 & 0.49 & 0.17 & 0.05 & 0.008 & 0.015 & 0.80 & 5.72 & 1.46 & 20.1 & 3.1 & 1.8 & 241 & 3.8 & 6.8 \\
\hline $\mathrm{U} 18 \mathrm{D}$ & & & 0.014 & 0.66 & 0.22 & 0.05 & 0.004 & 0.022 & 0.82 & 8.36 & 1.55 & 27.2 & 3.7 & 1.9 & 155 & 0.7 & 6.8 \\
\hline U1 9B & & & 0.014 & 1.67 & 0.27 & 0.05 & 0.007 & 0.015 & 0.93 & 10.22 & 1.69 & 31.4 & 3.9 & 2.2 & 38 & 2.5 & 16.3 \\
\hline U1 9C & & & 0.014 & 0.83 & 0.29 & 0.05 & 0.005 & 0.022 & 0.96 & 11.06 & 1.74 & 30.9 & 4.5 & 2.4 & 33 & 1.3 & 14.2 \\
\hline U1 10 & & & 0.014 & 0.87 & 0.20 & 0.04 & 0.002 & 0.015 & 0.96 & 14.08 & 1.77 & 36.7 & 4.8 & 2.4 & 11 & 2 & 14 \\
\hline U1 18 & & & 0.014 & 1.76 & 0.26 & 0.04 & 0.003 & 0.015 & 0.97 & 13.07 & 1.82 & 31 & 4.9 & 2.4 & 10 & 1.5 & 31.4 \\
\hline U1 19 & & & 0.007 & 0.73 & 0.19 & 0.04 & 0.003 & 0.007 & 0.95 & 11.61 & 1.73 & 26.1 & 4.8 & 1.9 & 10 & 1.1 & 33.1 \\
\hline AU-1a & & & 0.021 & 1.07 & 0.70 & 0.16 & 0.004 & 0.022 & 0.80 & 10.27 & 1.51 & 27.9 & 3.9 & 1.8 & 21 & 1.9 & 36.2 \\
\hline AU 2 & & & 0.021 & 1.55 & 0.88 & 0.21 & 0.003 & 0.022 & 0.81 & 12.13 & 1.49 & 26.2 & 4.2 & 1.8 & 27 & 1 & 23.1 \\
\hline Mean & & & 0.02 & 1.0 & 0.3 & 0.07 & 0.004 & 0.017 & 0.9 & 9.8 & 1.6 & 27.2 & 3.8 & 1.9 & 54 & 1.8 & 13.4 \\
\hline Median & & & 0.01 & 0.9 & 0.3 & 0.06 & 0.004 & 0.015 & 0.9 & 10.2 & 1.6 & 26.5 & 3.8 & 2.0 & 15 & 1.9 & 8.7 \\
\hline SD & & & 0.01 & 0.4 & 0.2 & 0.04 & 0.002 & 0.005 & 0.1 & 2.3 & 0.1 & 3.7 & 0.5 & 0.3 & 70 & 0.8 & 9.9 \\
\hline IM 2B & \multirow{2}{*}{$\begin{array}{l}\text { Mamu } \\
\text { Formation }\end{array}$} & \multirow{3}{*}{$\begin{array}{l}\text { Western margin } \\
(\text { Central Basin } \\
\text { subenvironment })\end{array}$} & 0.04 & 2.84 & 0.99 & 0.22 & 0.006 & 0.02 & 0.86 & 14.77 & 1.59 & 39.6 & 5.6 & 2.4 & 43 & 1.8 & 25.9 \\
\hline $1 \mathrm{M} 2 \mathrm{C}$ & & & 0.03 & 2.63 & 1.00 & 0.23 & 0.006 & 0.03 & 0.97 & 13.44 & 1.72 & 41.9 & 5.5 & 2.5 & 57 & 1.5 & 19.6 \\
\hline $1 \mathrm{M} 2 \mathrm{D}$ & & & 0.03 & 2.90 & 1.01 & 0.24 & 0.006 & 0.03 & 0.87 & 13.44 & 1.62 & 47.2 & 5.5 & 2 & 71 & 0.6 & 28.7 \\
\hline $1 \mathrm{M} 2 \mathrm{E}$ & & & 0.064 & 4.57 & 0.98 & 0.30 & 0.016 & 0.03 & 0.84 & 13.60 & 1.50 & 36.7 & 5.1 & 2.2 & 96 & 1.3 & 22.7 \\
\hline IM 4A & & & 0.021 & 4.59 & 0.71 & 0.18 & 0.007 & 0.03 & 0.71 & 10.48 & 1.24 & 32 & 4.3 & 1.7 & 43 & 1 & 14.7 \\
\hline IM 11A & & & 0.06 & 7.20 & 0.60 & 0.22 & 0.008 & 0.02 & 0.66 & 12.60 & 1.13 & 46.2 & 6.3 & 1.6 & 127 & 1 & 30.5 \\
\hline IM 11B & & & 0.06 & 4.02 & 1.00 & 0.29 & 0.010 & 0.03 & 0.69 & 16.62 & 1.12 & 30.7 & 5.6 & 1.8 & 67 & 1 & 32.1 \\
\hline IM 11C & & & 0.19 & 5.01 & 1.14 & 0.34 & 0.014 & 0.03 & 0.66 & 12.54 & 1.13 & 39.5 & 5.3 & 1.6 & 125 & 0.6 & 28.1 \\
\hline IM 13A & & & 0.11 & 7.41 & 1.00 & 0.41 & 0.092 & 0.03 & 0.60 & 13.44 & 1.05 & 26.8 & 4.7 & 1.6 & 106 & 1.2 & 31.1 \\
\hline $1 \mathrm{M} \mathrm{13B}$ & & & 0.043 & 3.30 & 1.06 & 0.30 & 0.008 & 0.03 & 0.76 & 15.35 & 1.30 & 29.2 & 5.4 & 2.2 & 94 & 1.1 & 35.1 \\
\hline IM 14A & & & 0.54 & 5.32 & 1.08 & 0.32 & 0.021 & 0.04 & 0.64 & 12.60 & 1.11 & 38.8 & 4.3 & 1.7 & 191 & 2 & 32.2 \\
\hline IM 16A & & & 0.26 & 12.52 & 1.20 & 0.42 & 0.253 & 0.02 & 0.39 & 11.86 & 0.70 & 25.9 & 3.8 & 1.3 & 128 & 2.2 & 28.9 \\
\hline IM 16B & & & 0.19 & 7.13 & 1.36 & 0.41 & 0.084 & 0.03 & 0.46 & 13.23 & 0.82 & 31 & 4 & 1.6 & 122 & 1.7 & 24.3 \\
\hline $1 \mathrm{M} 16 \mathrm{C}$ & & & 0.09 & 3.97 & 1.45 & 0.35 & 0.021 & 0.03 & 0.54 & 13.92 & 0.96 & 33.7 & 4.7 & 1.5 & 69 & 1.5 & 19.2 \\
\hline $1 \mathrm{M} 16 \mathrm{D}$ & & & 0.06 & 2.91 & 1.35 & 0.30 & 0.008 & 0.03 & 0.57 & 13.23 & 1.02 & 23.4 & 4.4 & 1.7 & 38 & 0.5 & 17.9 \\
\hline
\end{tabular}


Edegbai Aitalokhai Joel (2020) Differentiation of Sediment Source Regions in the Southern Benue Trough and Anambra Basin, Nigeria: Insights from Geochemistry of Upper Cretaceous Strata

\begin{tabular}{|c|c|c|c|c|c|c|c|c|c|c|c|c|c|c|c|c|c|}
\hline IM 18a & & & 0.79 & 0.93 & 1.06 & 0.13 & 0.004 & 0.03 & 0.42 & 11.63 & 0.72 & 28.5 & 2.75 & 0.9 & 47 & 1.1 & 9.75 \\
\hline IM 18C & & & 0.13 & 1.41 & 0.81 & 0.18 & 0.004 & 0.02 & 0.66 & 17.78 & 1.12 & 47 & 5.9 & 2.1 & 34 & 1.5 & 24.2 \\
\hline IM 19A & & & 0.10 & 1.96 & 1.10 & 0.24 & 0.004 & 0.02 & 0.61 & 17.25 & 1.05 & 41.9 & 5.4 & 1.9 & 37 & 2 & 36.5 \\
\hline IM 19B & & & 0.07 & 2.34 & 1.10 & 0.24 & 0.003 & 0.02 & 0.57 & 16.99 & 0.98 & 34 & 5.3 & 1.7 & 32 & 1 & 43.1 \\
\hline IM 19D & & & 0.05 & 3.43 & 0.92 & 0.19 & 0.007 & 0.03 & 0.61 & 16.53 & 1.08 & 46.3 & 5.1 & 2.2 & 33 & 1 & 209.1 \\
\hline IM 19E & & & 0.04 & 1.88 & 1.05 & 0.22 & 0.005 & 0.03 & 0.71 & 17.36 & 1.22 & 38.1 & 5.8 & 2.3 & 30 & 1.9 & 19.3 \\
\hline IM $2 \mathrm{~A}$ & & & 0.04 & 3.18 & 0.74 & 0.16 & 0.004 & 0.02 & 0.76 & 13.50 & 1.34 & 33.7 & 4.6 & 1.9 & 30 & 1.7 & 11.3 \\
\hline IM 4B & & & 0.014 & 4.12 & 0.48 & 0.11 & 0.007 & 0.01 & 0.65 & 7.55 & 1.10 & 29.5 & 3.5 & 1.3 & 32 & 1.4 & 22.8 \\
\hline IM 14C & & & 0.24 & 6.67 & 1.15 & 0.39 & 0.020 & 0.04 & 0.52 & 13.60 & 0.91 & 37.7 & 4.5 & 1.5 & 128 & 3.3 & 44 \\
\hline IM 18B & & & 0.16 & 1.50 & 0.70 & 0.15 & 0.004 & 0.02 & 0.64 & 16.68 & 1.01 & 41.1 & 5.9 & 1.7 & 36 & 2.2 & 111.1 \\
\hline IM 19C & & & 0.07 & 3.81 & 0.96 & 0.21 & 0.004 & 0.03 & 0.58 & 16.20 & 0.96 & 31.1 & 5 & 1.7 & 29 & 1.3 & 147.4 \\
\hline Mean & & & 0.13 & 4.1 & 1.0 & 0.3 & 0.02 & 0.03 & 0.7 & 14.1 & 1.1 & 35.8 & 4.9 & 1.8 & 71.0 & 1.4 & 41.1 \\
\hline Median & & & 0.07 & 3.6 & 1.0 & 0.2 & 0.01 & 0.03 & 0.7 & 13.6 & 1.1 & 35.4 & 5.1 & 1.7 & 52.0 & 1.4 & 28.4 \\
\hline SD & & & 0.17 & 2.5 & 0.2 & 0.1 & 0.05 & 0.01 & 0.1 & 2.4 & 0.3 & 6.9 & 0.8 & 0.4 & 44.2 & 0.6 & 45.3 \\
\hline OK 7A & \multirow{2}{*}{$\begin{array}{l}\text { Mamu } \\
\text { Formation }\end{array}$} & \multirow{3}{*}{$\begin{array}{l}\text { Western margin } \\
\quad \text { (Bay } \\
\text { subenvironment) }\end{array}$} & 0.014 & 3.28 & 0.46 & 0.12 & 0.004 & 0.015 & 0.86 & 12.01 & 1.51 & 46.6 & 5.7 & 2.3 & 80 & 3.2 & 18.3 \\
\hline OK 7B & & & 0.014 & 2.71 & 0.23 & 0.06 & 0.008 & 0.015 & 0.63 & 6.93 & 1.09 & 23.7 & 4.9 & 1.4 & 174 & 6.4 & 13 \\
\hline OK 7C & & & 0.014 & 6.76 & 0.46 & 0.12 & 0.018 & 0.030 & 0.50 & 15.61 & 0.90 & 71 & 5.5 & 1.7 & 96 & 7.9 & 40.7 \\
\hline OK 7D & & & 0.014 & 5.38 & 0.42 & 0.10 & 0.005 & 0.022 & 0.60 & 15.88 & 1.06 & 52.7 & 6.2 & 1.7 & 118 & 2.9 & 38.8 \\
\hline OK 7E & & & 0.014 & 2.42 & 0.40 & 0.08 & 0.002 & 0.022 & 0.94 & 14.98 & 1.76 & 48.7 & 6.5 & 2.8 & 145 & 2.5 & 25.7 \\
\hline OK 7F & & & 0.014 & 2.02 & 0.42 & 0.08 & 0.005 & 0.022 & 0.72 & 17.04 & 1.31 & 34.6 & 5.5 & 2.1 & 149 & 1.5 & 26.7 \\
\hline OK 7G & & & 0.021 & 1.96 & 0.47 & 0.07 & 0.003 & 0.030 & 0.73 & 11.54 & 1.34 & 35 & 6.5 & 2 & 29 & 1.8 & 18 \\
\hline OK 7H & & & 0.014 & 1.19 & 0.37 & 0.07 & 0.005 & 0.015 & 0.83 & 12.54 & 1.53 & 29.3 & 6.1 & 2 & 30 & 2.6 & 15.7 \\
\hline OK 7I & & & 0.021 & 1.43 & 0.39 & 0.07 & 0.003 & 0.022 & 0.87 & 15.24 & 1.51 & 46.9 & 7 & 2.1 & 37 & 2.8 & 30 \\
\hline OK 7J & & & 0.021 & 1.60 & 0.44 & 0.07 & 0.005 & 0.022 & 1.03 & 13.81 & 1.88 & 47.7 & 7.5 & 2.6 & 31 & 4.3 & 29.9 \\
\hline OK 9 & & & 0.021 & 0.80 & 0.42 & 0.08 & 0.002 & 0.015 & 0.76 & 16.88 & 1.37 & 41.1 & 5.6 & 2 & 33 & 1 & 19.1 \\
\hline OK $11 \mathrm{~A}$ & & & 0.014 & 1.63 & 0.64 & 0.12 & 0.005 & 0.022 & 0.99 & 15.40 & 1.71 & 36.4 & 7 & 2.7 & 31 & 3.3 & 17.8 \\
\hline OK 11B & & & 0.021 & 1.57 & 0.88 & 0.16 & 0.003 & 0.022 & 1.05 & 15.88 & 1.84 & 42.9 & 7.3 & 2.9 & 28 & 2.1 & 13.8 \\
\hline OK 13A & & & 0.014 & 1.29 & 0.45 & 0.07 & 0.004 & 0.022 & 0.88 & 13.07 & 1.56 & 38.4 & 7.2 & 2.2 & 30 & 3.5 & 27.1 \\
\hline OK 13B & & & 0.014 & 1.14 & 0.50 & 0.08 & 0.003 & 0.022 & 0.99 & 15.61 & 1.74 & 49 & 7.7 & 2.5 & 37 & 1.8 & 29.9 \\
\hline OK 15 & & & 0.021 & 0.62 & 0.51 & 0.05 & 0.004 & 0.030 & 0.94 & 8.10 & 1.70 & 36.8 & 7.3 & 2.3 & 18 & 1.5 & 13.7 \\
\hline OK 17 & & & 0.021 & 0.75 & 0.47 & 0.05 & 0.005 & 0.022 & 0.90 & 11.75 & 1.64 & 34.9 & 6.4 & 2.1 & 23 & 1.8 & 36.7 \\
\hline OK 19A & & & 0.014 & 0.68 & 0.41 & 0.06 & 0.003 & 0.022 & 0.93 & 13.92 & 1.66 & 37.7 & 7.2 & 2.2 & 31 & 1.1 & 59.3 \\
\hline OK 19B & & & 0.014 & 1.04 & 0.47 & 0.08 & 0.003 & 0.022 & 1.04 & 15.72 & 1.78 & 47.5 & 7.6 & 2.7 & 37 & 1.9 & 32.7 \\
\hline OK $21 \mathrm{~A}$ & & & 0.029 & 1.20 & 0.60 & 0.09 & 0.003 & 0.022 & 1.14 & 10.43 & 2.00 & 41.6 & 8 & 2.9 & 23 & 1 & 20.3 \\
\hline OK 21B & & & 0.021 & 1.55 & 0.62 & 0.10 & 0.003 & 0.022 & 1.11 & 11.91 & 2.01 & 40.7 & 7.9 & 2.7 & 23 & 1.7 & 17.8 \\
\hline OK $24 \mathrm{~A}$ & & & 0.014 & 0.62 & 0.42 & 0.06 & 0.002 & 0.022 & 0.96 & 13.87 & 1.65 & 42.5 & 7.5 & 2.3 & 30 & 1.5 & 63.6 \\
\hline Ok 24B & & & 0.014 & 0.64 & 0.41 & 0.05 & 0.004 & 0.022 & 0.88 & 10.06 & 1.53 & 43.4 & 6.2 & 1.9 & 19 & 1.9 & 26.4 \\
\hline Mean & & & 0.017 & 1.8 & 0.5 & 0.08 & 0.004 & 0.022 & 0.9 & 13.4 & 1.6 & 42.1 & 6.7 & 2.3 & 54.4 & 2.6 & 27.6 \\
\hline Median & & & 0.014 & 1.5 & 0.5 & 0.08 & 0.004 & 0.022 & 0.9 & 13.9 & 1.7 & 41.6 & 7 & 2.2 & 31.0 & 1.9 & 26.4 \\
\hline SD & & & 0.004 & 1.5 & 0.1 & 0.03 & 0.003 & 0.004 & 0.2 & 2.7 & 0.3 & 9.3 & 0.7 & 0.4 & 47.4 & 1.7 & 13.4 \\
\hline $\mathrm{Nz}-16$ & \multirow{2}{*}{$\begin{array}{l}\text { Mamu } \\
\text { Formation }\end{array}$} & Nzam-1 Well & 0.74 & 4.35 & 1.36 & 0.65 & 0.07 & 0.514 & 0.57 & 7.74 & 0.96 & 25.9 & 2.1 & 7.5 & 89 & 1.6 & 15 \\
\hline $\mathrm{Nz}-17$ & & & 0.51 & 4.96 & 1.17 & 0.58 & 0.04 & 0.625 & 0.65 & 9.34 & 1.09 & 25 & 2.9 & 16.8 & 126 & 2.3 & 18.7 \\
\hline $\mathrm{Nz}-18$ & & & 0.47 & 6.31 & 1.06 & 0.81 & 0.02 & 0.619 & 0.54 & $>20$ & 0.90 & 27.2 & 3.4 & 3.7 & 155 & 2 & 27.3 \\
\hline $\mathrm{Nz}-19$ & & & 0.17 & 3.61 & 2.02 & 0.39 & 0.03 & 0.404 & 0.81 & 10.00 & 1.36 & 24.8 & 3.4 & 81.9 & 119 & 1.3 & 22.2 \\
\hline
\end{tabular}


Edegbai Aitalokhai Joel (2020) Differentiation of Sediment Source Regions in the Southern Benue Trough and Anambra Basin, Nigeria: Insights from Geochemistry of Upper Cretaceous Strata

\begin{tabular}{|c|c|c|c|c|c|c|c|c|c|c|c|c|c|c|c|c|c|}
\hline $\mathrm{Nz}-20$ & & & 0.32 & 3.97 & 0.79 & 0.46 & 0.03 & 0.485 & 0.44 & 6.95 & 0.74 & 17 & 2 & 2 & 65 & 2.5 & 21.1 \\
\hline $\mathrm{Nz}-21$ & & & 0.34 & 4.29 & 1.29 & 0.50 & 0.05 & 0.566 & 0.66 & 8.60 & 1.11 & 23.3 & 2.8 & 2 & 94 & 1.4 & 17.3 \\
\hline $\mathrm{Nz}-22$ & & & 0.34 & 3.13 & 1.16 & 0.32 & 0.03 & 0.564 & 0.61 & 7.89 & 1.02 & 23.8 & 2.5 & 3.4 & 64 & 1.2 & 13.7 \\
\hline $\mathrm{Nz}-39$ & & & 0.36 & 6.69 & 1.13 & 0.65 & 0.18 & 0.467 & 0.81 & 7.73 & 1.36 & 20.9 & 3.1 & 36.6 & 95 & 1.6 & 18.7 \\
\hline Mean & & & 0.4 & 4.7 & 1.3 & 0.6 & 0.056 & 0.531 & 0.6 & 8.3 & 1.1 & 23.5 & 2.8 & 19.2 & 100.9 & 1.7 & 19.3 \\
\hline Median & & & 0.4 & 4.3 & 1.2 & 0.5 & 0.034 & 0.539 & 0.6 & 7.9 & 1.1 & 24.3 & 2.9 & 5.6 & 94.5 & 1.6 & 18.7 \\
\hline SD & & & 0.2 & 1.3 & 0.4 & 0.2 & 0.051 & 0.077 & 0.1 & 1.1 & 0.2 & 3.22 & 0.5 & 27.9 & 31.1 & 0.5 & 4.3 \\
\hline ID-3 & \multirow{2}{*}{$\begin{array}{l}\text { Mamu } \\
\text { Formation }\end{array}$} & Idah-1 Well & 0.07 & 0.25 & 0.02 & 0.01 & 0.005 & 0.014 & 0.28 & 0.15 & 0.46 & 126 & 0.7 & 7.9 & 9 & 0.3 & 2.3 \\
\hline ID-4 & & & 0.02 & 1.07 & 1.59 & 0.06 & 0.006 & 0.074 & 0.57 & 4.80 & 0.94 & 22 & 1.5 & 103 & 31 & 1.6 & 8.9 \\
\hline ID-5 & & & 0.23 & 2.45 & 0.61 & 0.37 & 0.040 & 0.126 & 0.33 & 3.66 & 0.54 & 179 & 2.6 & 3.2 & 52 & 0.6 & 9.8 \\
\hline ID-6 & & & 0.37 & 4.80 & 1.26 & 0.80 & 0.046 & 0.462 & 0.81 & 8.28 & 1.34 & 75.4 & 3.3 & 3.2 & 88 & 1.4 & 20.3 \\
\hline ID-7 & & & 0.48 & 5.27 & 1.34 & 0.71 & 0.050 & 0.469 & 1.09 & 6.70 & 1.82 & 148 & 3.8 & 4.9 & 92 & 1.9 & 24.2 \\
\hline ID-8 & & & 0.43 & 5.78 & 1.19 & 0.84 & 0.079 & 0.432 & 0.71 & 7.56 & 1.18 & 2290 & 19.1 & 23.2 & 186 & 1.4 & 21.4 \\
\hline ID-9 & & & 0.48 & 5.00 & 1.05 & 0.71 & 0.065 & 0.454 & 0.63 & 7.24 & 1.06 & 2400 & 18 & 51.6 & 241 & 1.6 & 19.9 \\
\hline ID- 10 & & & 0.73 & 6.82 & 0.80 & 1.09 & 0.083 & 0.314 & 0.62 & 4.87 & 1.04 & 325 & 4.7 & 25.1 & 152 & 1.7 & 14 \\
\hline ID-11 & & & 0.43 & 4.74 & 0.83 & 0.77 & 0.066 & 0.402 & 0.84 & 5.78 & 1.40 & 222 & 3.7 & 4.8 & 95 & 1.3 & 19.7 \\
\hline ID-12 & & & 0.73 & 7.05 & 0.93 & 0.83 & 0.080 & 0.280 & 0.64 & 6.19 & 1.07 & 450 & 6.1 & 57.2 & 138 & 1.7 & 21.8 \\
\hline ID-13 & & & 0.58 & 5.81 & 1.09 & 0.55 & 0.051 & 0.315 & 0.77 & 7.74 & 1.29 & 126 & 3.8 & 16.6 & 187 & 1.5 & 20.7 \\
\hline ID-14 & & & 0.39 & 6.47 & 1.17 & 0.64 & 0.051 & 0.377 & 0.82 & 9.23 & 1.37 & 1250 & 11.3 & $\mid 13.1$ & 146 & 1.4 & 23.4 \\
\hline ID-15 & & & 0.40 & 7.13 & 1.08 & 0.66 & 0.063 & 0.341 & 0.77 & 8.47 & 1.28 & 249 & 5 & 3.1 & 139 & 1.5 & 20.8 \\
\hline ID-16 & & & 0.25 & 4.82 & 1.11 & 0.48 & 0.018 & 0.366 & 1.23 & 9.59 & 2.05 & 31.5 & 4.6 & 17.1 & 114 & 1.1 & 22.8 \\
\hline ID-17 & & & 0.16 & 4.81 & 1.02 & 0.44 & 0.029 & 0.229 & 0.90 & 10.70 & 1.49 & 163 & 6.2 & 76.1 & 150 & 1.4 & 21.4 \\
\hline ID-18 & & & 0.35 & 7.09 & 1.05 & 0.53 & 0.047 & 0.256 & 0.71 & 10.00 & 1.19 & 666 & 8.3 & 2.4 & 136 & 0.8 & 24.3 \\
\hline ID-19 & & & 0.44 & 5.97 & 0.88 & 0.54 & 0.031 & 0.231 & 0.67 & 9.47 & 1.12 & 334 & 6.6 & 2.9 & 214 & 1.3 & 20.4 \\
\hline ID-20 & & & 0.36 & 5.94 & 1.07 & 0.68 & 0.047 & 0.334 & 0.69 & 9.92 & 1.15 & 222 & 4.8 & 2.3 & 160 & 1.7 & 21.7 \\
\hline ID-21 & & & 0.69 & 5.34 & 1.30 & 1.06 & 0.024 & 0.452 & 0.57 & 10.70 & 0.95 & 146 & 4.4 & 2.2 & 208 & 0.7 & 25.4 \\
\hline ID-22 & & & 0.53 & 5.27 & 1.40 & 1.09 & 0.031 & 0.446 & 0.57 & 10.80 & 0.95 & 97.1 & 3.6 & 2.1 & 151 & 0.6 & 23.5 \\
\hline ID-23 & & & 0.71 & 5.23 & 1.20 & 0.98 & 0.050 & 0.431 & 0.63 & 9.37 & 1.05 & 97.7 & 4.1 & 5.5 & 203 & 0.9 & 22.4 \\
\hline Mean & & & 0.4 & 5.1 & 1.1 & 0.7 & 0.05 & 0.32 & 0.7 & 7.7 & 1.2 & 458.1 & 6.0 & 20.4 & 137.7 & 1.3 & 19.5 \\
\hline Median & & & 0.4 & 5.3 & 1.1 & 0.7 & 0.05 & 0.34 & 0.7 & 8.3 & 1.2 & 179 & 4.6 & 5.5 & 146 & 1.4 & 21.4 \\
\hline SD & & & 0.2 & 1.8 & 0.3 & 0.3 & 0.02 & 0.13 & 0.2 & 2.7 & 0.4 & 683.5 & 4.7 & 28.1 & 60.8 & 0.4 & 5.9 \\
\hline OW-10 & \multirow{2}{*}{$\begin{array}{l}\text { Mamu } \\
\text { Formation }\end{array}$} & Owan-1 Well & 0.02 & 0.76 & 0.03 & 0.02 & 0.004 & 0.010 & 0.46 & 1.54 & 0.76 & 11.3 & 1.1 & $>200$ & 30 & 1.3 & 1.4 \\
\hline OW-11 & & & 0.03 & 0.70 & 0.32 & 0.06 & 0.005 & 0.018 & 0.74 & 9.72 & 1.23 & 30.2 & 3.5 & 2.9 & 100 & 0.2 & 29.8 \\
\hline OW-12 & & & 0.01 & 0.34 & 0.07 & 0.02 & 0.004 & 0.010 & 0.13 & 3.54 & 0.22 & 14 & 0.5 & 4.4 & 26 & $<0.1$ & 4.7 \\
\hline OW-13 & & & 0.01 & 0.20 & 0.07 & 0.02 & 0.003 & 0.009 & 0.30 & 2.93 & 0.50 & 11.8 & 0.5 & 15.4 & 18 & 0.2 & 3.9 \\
\hline OW-14 & & & 0.04 & 1.66 & 0.19 & 0.08 & 0.011 & 0.012 & 0.73 & 7.37 & 1.21 & 34.1 & 2.5 & 42.1 & 66 & 3.9 & 13.6 \\
\hline OW-15 & & & 0.12 & 1.47 & 0.21 & 0.05 & 0.008 & 0.016 & 0.92 & 6.45 & 1.54 & 24 & 2.5 & 169 & 40 & 1.3 & 11.2 \\
\hline OW-16 & & & 0.03 & 0.76 & 0.10 & 0.02 & 0.004 & 0.008 & 0.45 & 2.44 & 0.75 & 11.1 & 1.1 & 185 & 50 & 0.6 & 5.2 \\
\hline Mean & & & 0.04 & 0.8 & 0.1 & 0.04 & 0.006 & 0.012 & 0.5 & 4.9 & 0.9 & 19.5 & 1.7 & 69.8 & 47.1 & 1.3 & 10 \\
\hline Median & & & 0.03 & 0.8 & 0.1 & 0.02 & 0.004 & 0.010 & 0.5 & 3.5 & 0.8 & 14 & 1.1 & 28.8 & 40 & 1 & 5.2 \\
\hline SD & & & 0.04 & 0.5 & 0.1 & 0.03 & 0.003 & 0.004 & 0.3 & 3.0 & 0.5 & 9.8 & 1.2 & 84.4 & 28.3 & 1.4 & 9.7 \\
\hline $\mathrm{Am}-3$ & \multirow{2}{*}{$\begin{array}{l}\text { Mamu } \\
\text { Formation }\end{array}$} & \multirow{2}{*}{$\begin{array}{l}\text { Amansiodo-1 } \\
\text { Well }\end{array}$} & 4.82 & 0.62 & 0.04 & 0.07 & 0.007 & \begin{tabular}{|l|}
0.024 \\
\end{tabular} & 0.06 & 0.65 & 0.10 & 28.5 & 1.3 & $>200$ & 61 & 1.5 & 20.9 \\
\hline $\mathrm{Am}-4$ & & & 6.28 & 0.69 & \begin{tabular}{|l}
0.03 \\
\end{tabular} & 0.09 & \begin{tabular}{|l|}
0.009 \\
\end{tabular} & 0.022 & 0.06 & 0.72 & 0.11 & 27.7 & 1.5 & $>200$ & 78 & 1.6 & 28.1 \\
\hline
\end{tabular}


Edegbai Aitalokhai Joel (2020) Differentiation of Sediment Source Regions in the Southern Benue Trough and Anambra Basin, Nigeria: Insights from Geochemistry of Upper Cretaceous Strata

\begin{tabular}{|c|c|c|c|c|c|c|c|c|c|c|c|c|c|c|c|c|c|}
\hline Am-5 & & & 3.95 & 1.67 & 0.05 & 0.12 & 0.014 & 0.050 & 0.08 & 0.87 & 0.14 & 42.2 & 1.2 & $>200$ & 111 & 1.8 & 21.1 \\
\hline Am-6 & & & 1.16 & 0.52 & 0.03 & 0.03 & 0.008 & 0.015 & 0.06 & 0.54 & 0.11 & 19 & 0.5 & 191 & 37 & 0.9 & 13.5 \\
\hline $\mathrm{Am}-7$ & & & 0.51 & 0.62 & 0.04 & 0.02 & 0.005 & 0.014 & 0.06 & 0.62 & 0.11 & 42.2 & 0.7 & $>200$ & 59 & 1.2 & 6.5 \\
\hline Am-8 & & & 0.38 & 0.54 & 0.04 & 0.02 & 0.005 & 0.014 & 0.07 & 0.66 & 0.12 & 36.4 & 0.4 & 195 & 55 & 1 & 4.7 \\
\hline Am-9 & & & 0.10 & 0.43 & 0.03 & 0.02 & 0.003 & 0.010 & 0.05 & 0.51 & 0.08 & 24.1 & 0.4 & $>200$ & 34 & 1 & 3.9 \\
\hline $\mathrm{Am}-10$ & & & 0.50 & 0.57 & 0.02 & 0.02 & 0.004 & 0.007 & 0.03 & 0.26 & 0.05 & 31.2 & 0.4 & 195 & 31 & 2.5 & 5.3 \\
\hline Am-11 & & & 0.85 & 2.50 & 0.03 & 0.04 & 0.012 & 0.011 & 0.07 & 0.62 & 0.12 & 86.5 & 0.6 & 196 & 58 & 1.4 & 8.2 \\
\hline Mean & & & 2.1 & 0.9 & 0.03 & 0.05 & 0.007 & 0.019 & 0.06 & 0.6 & 0.1 & 37.5 & 0.8 & 194.3 & 58.2 & 1.4 & 12.5 \\
\hline Median & & & 0.9 & 0.6 & 0.03 & 0.03 & 0.007 & 0.014 & 0.06 & 0.6 & 0.1 & 31.2 & 0.6 & 195 & 58 & 1.4 & 8.2 \\
\hline SD & & & 2.1 & 0.6 & 0.01 & 0.03 & 0.003 & 0.012 & 0.01 & 0.15 & 0.02 & 20.0 & 0.4 & 2.2 & 24.9 & 0.5 & 8.9 \\
\hline Enu 1.1 & \multirow{2}{*}{$\begin{array}{l}\text { Mamu } \\
\text { Formation }\end{array}$} & Eastern margin & 0.04 & 4.16 & 0.95 & 0.36 & 0.04 & 0.16 & 0.86 & 10.24 & 0.86 & 35 & - & - & 122 & - & 30 \\
\hline Enu 1.2 & & \multirow{2}{*}{$\begin{array}{c}\text { (Odoma et al., } \\
2015)\end{array}$} & 0.03 & 3.11 & 1.11 & 0.28 & 0.02 & 0.24 & 0.97 & 8.03 & 0.97 & 30 & - & - & 53 & - & 18 \\
\hline Enu 1.3 & & & 0.03 & 1.90 & 1.19 & 0.30 & 0.01 & 0.27 & 1.01 & 8.46 & 1.01 & 29 & - & - & 53 & - & 11 \\
\hline Enu 1.4 & & & 0.03 & 3.68 & 1.04 & 0.22 & 0.03 & 0.23 & 0.93 & 8.91 & 0.93 & 32 & - & - & 69 & - & 25 \\
\hline Enu 1.5 & & & 0.03 & 3.64 & 1.02 & 0.28 & 0.03 & 0.19 & 0.88 & 8.94 & 0.88 & 29 & - & - & 78 & - & 27 \\
\hline Enu 2.2 & & & 0.02 & 8.25 & 0.85 & 0.25 & 0.01 & 0.13 & 0.85 & 10.76 & 0.85 & 25 & - & - & 51 & - & 22 \\
\hline Enu2.3 & & & 0.03 & 5.71 & 0.87 & 0.25 & 0.01 & 0.14 & 1.02 & 10.56 & 1.02 & 24 & - & - & 39 & - & 26 \\
\hline Enu2.4 & & & 0.03 & 2.58 & 1.46 & 0.37 & 0.01 & 0.16 & 0.92 & 11.64 & 0.92 & 23 & - & - & 51 & - & 31 \\
\hline Enu2.5 & & & 0.04 & 4.71 & 0.96 & 0.27 & 0.01 & 0.17 & 1.21 & 10.37 & 1.21 & 27 & - & - & 152 & - & 27 \\
\hline mean & & & 0.03 & 4.2 & 1.1 & 0.3 & 0.02 & 0.19 & 1.0 & 9.8 & 1.0 & 28.2 & - & - & 74.2 & - & 24.1 \\
\hline median & & & 0.03 & 3.7 & 1.0 & 0.3 & 0.01 & 0.17 & 0.9 & 10.2 & 0.9 & 29 & - & - & 53 & - & 26 \\
\hline SD & & & 0.01 & 1.9 & 0.2 & 0.1 & 0.01 & 0.05 & 0.1 & 1.2 & 0.1 & 3.9 & - & - & 38.1 & - & 6.3 \\
\hline & \multirow{2}{*}{$\begin{array}{c}\text { Mamu Formation } \\
\text { average }\end{array}$} & & 0.05 & 5.1 & 1.4 & 0.9 & 0.05 & 1.06 & 0.7 & 9.3 & 1.1 & 29.6 & 3.8 & 5.5 & 52.5 & 1.4 & 20.1 \\
\hline & & & & & & & & & & & & & & & & & \\
\hline & \multicolumn{2}{|c|}{ Pre-Santonian Units } & & & & & & & & & & & & & & & \\
\hline $\mathrm{Am}-23$ & \multirow{2}{*}{$\begin{array}{l}\text { Awgu } \\
\text { Group }\end{array}$} & \multirow{2}{*}{$\begin{array}{l}\text { Amansiodo-1 } \\
\text { Well }\end{array}$} & 0.54 & 8.56 & 1.18 & 0.78 & 0.121 & 0.453 & 1.05 & 10.30 & 1.75 & \begin{tabular}{|l}
24.5 \\
\end{tabular} & 3.8 & 5.9 & 106 & 1.7 & 26.7 \\
\hline $\mathrm{Am}-24$ & & & 0.34 & 5.56 & 1.96 & 0.83 & 0.046 & 0.528 & 0.99 & 12.0 & 1.64 & 27.8 & 4 & 8 & 125 & 2.6 & 31.4 \\
\hline Am-25 & & & 0.27 & 5.64 & 1.62 & 0.74 & 0.039 & 0.526 & 0.98 & 11.60 & 1.64 & 27.2 & 4 & 9.7 & 107 & 1.5 & 29 \\
\hline Am-26 & & & 0.46 & 6.18 & 2.25 & 1.03 & 0.076 & 0.610 & 0.87 & 11.40 & 1.45 & 25.6 & 3.7 & 12.4 & 119 & 1.3 & 28.5 \\
\hline Am-27 & & & 0.31 & 5.41 & 1.93 & 1.16 & 0.042 & 0.646 & 0.77 & 11.90 & 1.28 & 28.7 & 4 & 5.3 & 123 & 1.5 & 23.7 \\
\hline $\mathrm{Am}-28$ & & & 0.29 & 5.24 & 1.51 & 0.95 & 0.042 & 0.590 & 0.84 & 11.60 & 1.41 & 25.6 & 3.8 & 4.2 & 110 & 1.6 & 24.6 \\
\hline Am-29 & & & 0.33 & 5.89 & 1.48 & 1.01 & 0.056 & 0.640 & 0.77 & 12.50 & 1.28 & 27.1 & 3.9 & 3.8 & 109 & 0.9 & 23.2 \\
\hline Am-30 & & & 0.31 & 5.98 & 1.27 & 0.99 & 0.047 & 0.649 & 0.76 & 11.40 & 1.27 & 30.8 & 4.4 & 6.1 & 194 & 1.3 & 25.4 \\
\hline Am-31 & & & 0.29 & 5.79 & 1.43 & 1.04 & 0.052 & 0.706 & 0.76 & 12.90 & 1.27 & 25.4 & 4 & 2.4 & 132 & 1.5 & 24.9 \\
\hline $\mathrm{Am}-32$ & & & 0.34 & 5.74 & 1.44 & 1.01 & 0.048 & 0.723 & 0.86 & 12.90 & 1.43 & 24.8 & 4 & 5.5 & 104 & 2.4 & 23.3 \\
\hline $\mathrm{Am}-33$ & & & 0.28 & 5.73 & 1.77 & 1.01 & 0.045 & 0.654 & 0.83 & 13.0 & 1.39 & 25.9 & 4 & 4.9 & 103 & 3.8 & 33.6 \\
\hline $\mathrm{Am}-34$ & & & 0.27 & 5.76 & 1.70 & 1.06 & 0.055 & 0.721 & 0.77 & 12.70 & 1.29 & 26.6 & 3.9 & 2.6 & 89 & 3.7 & 42.1 \\
\hline Am-35 & & & 1.10 & 4.74 & 3.75 & 1.08 & 0.073 & 0.569 & 0.65 & 12.70 & 1.08 & 32.6 & 4.4 & 12 & 160 & 5.3 & 30.5 \\
\hline $\mathrm{Am}-36$ & & & 1.28 & 8.86 & 1.16 & 1.56 & 0.110 & 0.743 & 0.56 & 9.69 & 0.93 & 23.4 & 3.6 & 9.3 & 88 & 2.7 & 17.7 \\
\hline Am-37 & & & 0.78 & 5.99 & 1.65 & 1.21 & 0.075 & 0.763 & 0.65 & 10.90 & 1.08 & 23.4 & 4.2 & 12 & 87 & 2.1 & 22.7 \\
\hline Mean & & & 0.5 & 6.1 & 1.7 & 1.0 & 0.062 & 0.635 & 0.8 & 11.8 & 1.4 & 26.6 & 4 & 6.9 & 117.1 & 2.3 & 27.2 \\
\hline Median & & & 0.3 & 5.8 & 1.6 & 1.0 & 0.052 & 0.646 & 0.8 & 11.9 & 1.3 & 25.9 & 4 & 5.9 & 109 & 1.7 & 25.4 \\
\hline SD & & & 0.3 & 1.1 & 0.6 & 0.2 & 0.025 & 0.090 & 0.1 & 1.0 & 0.2 & 2.6 & 0.2 & 3.4 & 28.4 & 1.2 & 5.8 \\
\hline
\end{tabular}


Edegbai Aitalokhai Joel (2020) Differentiation of Sediment Source Regions in the Southern Benue Trough and Anambra Basin, Nigeria: Insights from Geochemistry of Upper Cretaceous Strata

\begin{tabular}{|c|c|c|c|c|c|c|c|c|c|c|c|c|c|c|c|c|c|}
\hline Ak-4 & $\begin{array}{l}\text { Awgu } \\
\text { Group }\end{array}$ & & 0.53 & 5.73 & 1.25 & 0.74 & 0.024 & 0.733 & 0.551 & 10.90 & 0.92 & 24.9 & 3.3 & 6.8 & 130 & 2.8 & 49.8 \\
\hline Ak-5 & & & 0.54 & 5.38 & 1.09 & 0.76 & 0.027 & 0.729 & 0.711 & 11.80 & 1.19 & 28 & 3.8 & 5.7 & 161 & 3.3 & 34.8 \\
\hline Ak-6 & & & 0.53 & 4.95 & 1.11 & 0.92 & 0.025 & 0.719 & 0.614 & 10.90 & 1.02 & 21.6 & 3.3 & 11.7 & 125 & 2.2 & 40.1 \\
\hline Ak-7 & & & 0.38 & 5.58 & 0.95 & 1.12 & 0.091 & 0.778 & 0.708 & 10.60 & 1.18 & 25.5 & 3.2 & 10.4 & 122 & 2.7 & 32.7 \\
\hline Ak-8 & & & 0.29 & 5.03 & 1.29 & 1.03 & 0.028 & 0.814 & 0.710 & 11.70 & 1.18 & 28.6 & 3.6 & 9.2 & 174 & 4.1 & 33.3 \\
\hline Ak-9 & & & 0.46 & 5.91 & 1.27 & 1.14 & 0.075 & 0.697 & 0.674 & 11.20 & 1.12 & 26.8 & 3.3 & 9.7 & 158 & 2.6 & 32.9 \\
\hline Ak-10 & & & 0.42 & 3.19 & 0.86 & 0.44 & 0.041 & 1.340 & 0.281 & 6.60 & 0.47 & 26.4 & 1.7 & 68.1 & 82 & 1.9 & 14.4 \\
\hline Ak-11 & & & 0.31 & 5.47 & 1.45 & 0.79 & 0.045 & 0.689 & 0.800 & 11.0 & 1.33 & 24.4 & 3.6 & 8.8 & 128 & 2.3 & 30.5 \\
\hline Mean & & & 0.5 & 5.4 & 1.2 & 0.9 & 0.047 & 0.805 & 0.618 & 10.5 & 1.0 & 25.4 & 3.2 & 15.1 & 136.3 & 2.7 & 33.7 \\
\hline Median & & & 0.5 & 5.5 & 1.2 & 0.9 & 0.041 & 0.733 & 0.674 & 10.9 & 1.1 & 25.5 & 3.3 & 9.2 & 130 & 2.6 & 33.3 \\
\hline SD & & & 0.1 & 1.0 & 0.2 & 0.3 & 0.025 & 0.204 & 0.154 & 1.6 & 0.3 & 2.4 & 0.6 & 20 & 27.4 & 0.7 & 9.3 \\
\hline Ak-12 & \multirow{2}{*}{$\begin{array}{l}\text { Eze-Aku } \\
\text { Group }\end{array}$} & Akukwa-II Well & 0.30 & 5.30 & 1.22 & 0.84 & 0.052 & 0.725 & 0.767 & 11.80 & 1.28 & 24.2 & 3.6 & 7.6 & 225 & 2.2 & 34.3 \\
\hline Ak-13 & & & 0.42 & 5.43 & 1.25 & 0.92 & 0.066 & 0.737 & 0.702 & 11.30 & 1.17 & 18.9 & 3.3 & 15.3 & 133 & 3.1 & 31.8 \\
\hline Ak-14 & & & 0.73 & 12.80 & 1.28 & 2.53 & 0.470 & 0.430 & 0.431 & 7.65 & 0.72 & 24.4 & 2.3 & 2.5 & 55 & 0.7 & 18.2 \\
\hline Ak-15 & & & 0.36 & 4.84 & 1.76 & 0.86 & 0.060 & 0.659 & 0.694 & 10.30 & 1.16 & 23.3 & 3.6 & 15.4 & 134 & 2.4 & 29.7 \\
\hline Ak-16 & & & 0.38 & 5.11 & 1.28 & 0.94 & 0.042 & 0.760 & 0.673 & 9.68 & 1.12 & 22.2 & 3.3 & 13.6 & 147 & 2.6 & 30 \\
\hline Ak-17 & & & 0.27 & 5.46 & 1.19 & 0.97 & 0.057 & 0.829 & 0.762 & 11.60 & 1.27 & 29.2 & 3.9 & 9.4 & 134 & 2.1 & 32.8 \\
\hline Ak-18 & & & 0.39 & 4.64 & 1.38 & 0.87 & 0.043 & 1.060 & 0.633 & 10.0 & 1.06 & 21.3 & 3.6 & 13.4 & 190 & 3 & 28.3 \\
\hline Ak-19 & & & 6.77 & 4.31 & 1.24 & 0.85 & 0.053 & 0.925 & 0.519 & 7.90 & 0.87 & 19.6 & 3.1 & 11 & 153 & 12.7 & 28.7 \\
\hline Ak-20 & & & 1.62 & 4.82 & 1.47 & 0.96 & 0.049 & 1.070 & 0.659 & 9.43 & 1.10 & 16.8 & 3.6 & 14.1 & 137 & 3.2 & 27.9 \\
\hline Ak-21 & & & 1.55 & 4.57 & 1.44 & 0.89 & 0.052 & 1.040 & 0.663 & 9.13 & 1.11 & 24.6 & 3.6 & 13.8 & 150 & 3.1 & 26.6 \\
\hline Ak-22 & & & 1.82 & 4.08 & 1.43 & 0.71 & 0.037 & 1.430 & 0.647 & 9.25 & 1.08 & 24 & 3.4 & 16.7 & 119 & 2.8 & 21.9 \\
\hline Ak-23 & & & 12.90 & 5.60 & 0.99 & 0.75 & 0.102 & 0.664 & 0.369 & 6.56 & 0.62 & 113 & 4 & 21.3 & 383 & 11.3 & 177 \\
\hline Ak-24 & & & 2.43 & 5.47 & 2.04 & 1.15 & 0.074 & 1.430 & 0.757 & 10.50 & 1.26 & 38.5 & 4.4 & 18.1 & 135 & 2.9 & 30.2 \\
\hline Ak-25 & & & 2.11 & 5.76 & 1.89 & 1.12 & 0.072 & 1.530 & 0.771 & 10.50 & 1.29 & 44.8 & 4.6 & 15.5 & 145 & 3.8 & 34.3 \\
\hline Ak-26 & & & 2.07 & 5.77 & 1.95 & 1.15 & 0.080 & 1.520 & 0.781 & 9.98 & 1.30 & 35.6 & 4.5 & 18.5 & 111 & 3.8 & 21.9 \\
\hline Ak-27 & & & 1.49 & 5.06 & 1.52 & 0.92 & 0.055 & 1.230 & 0.655 & 8.64 & 1.09 & 39.1 & 3.9 & 13.2 & 100 & 2.9 & 31.9 \\
\hline Ak-28 & & & 2.14 & 5.07 & 1.76 & 0.94 & 0.050 & 1.420 & 0.724 & 8.62 & 1.21 & 30.8 & 4 & 22.2 & 88 & 1.7 & 20.2 \\
\hline Ak-29 & & & 1.49 & 4.33 & 1.29 & 0.81 & 0.042 & 1.040 & 0.524 & 7.86 & 0.87 & 27.4 & 3.5 & 24.2 & 92 & 3.1 & 30.8 \\
\hline Ak-30 & & & 2.13 & 5.01 & 1.64 & 0.90 & 0.045 & 1.140 & 0.661 & 8.67 & 1.10 & 24 & 4.2 & 8.1 & 109 & 5.1 & 29.9 \\
\hline Ak-31 & & & 3.56 & 4.13 & 1.41 & 0.52 & 0.043 & 1.280 & 0.451 & 8.18 & 0.75 & 32.4 & 3.5 & 36.5 & 98 & 3.8 & 28.3 \\
\hline Ak-32 & & & 3.12 & 4.41 & 1.48 & 0.78 & 0.047 & 1.210 & 0.529 & 8.21 & 0.88 & 32.8 & 3.5 & 26.7 & 131 & 4.2 & 25.9 \\
\hline Mean & & & 2.3 & 5.3 & 1.5 & 1.0 & 0.076 & 1.054 & 0.637 & 9.3 & 1.1 & 31.8 & 3.7 & 16.1 & 141 & 3.8 & 35.3 \\
\hline Median & & & 1.6 & 5.1 & 1.4 & 0.9 & 0.052 & 1.060 & 0.661 & 9.3 & 1.1 & 24.6 & 3.6 & 15.3 & 134 & 3.1 & 29.7 \\
\hline SD & & & 2.9 & 1.8 & 0.3 & 0.4 & 0.092 & 0.319 & 0.121 & 1.4 & 0.2 & 20.0 & 0.5 & 7.4 & 66.0 & 2.9 & 32.8 \\
\hline UCC & & & 3.0 & 3.5 & 2.8 & 1.33 & 0.06 & 2.89 & 0.41 & 8.04 & 0.68 & 17 & 5.5 & 2.0 & 71 & 1.5 & 25 \\
\hline
\end{tabular}


Edegbai Aitalokhai Joel (2020) Differentiation of Sediment Source Regions in the Southern Benue Trough and Anambra Basin, Nigeria: Insights from Geochemistry of Upper Cretaceous Strata

Appendix 1b

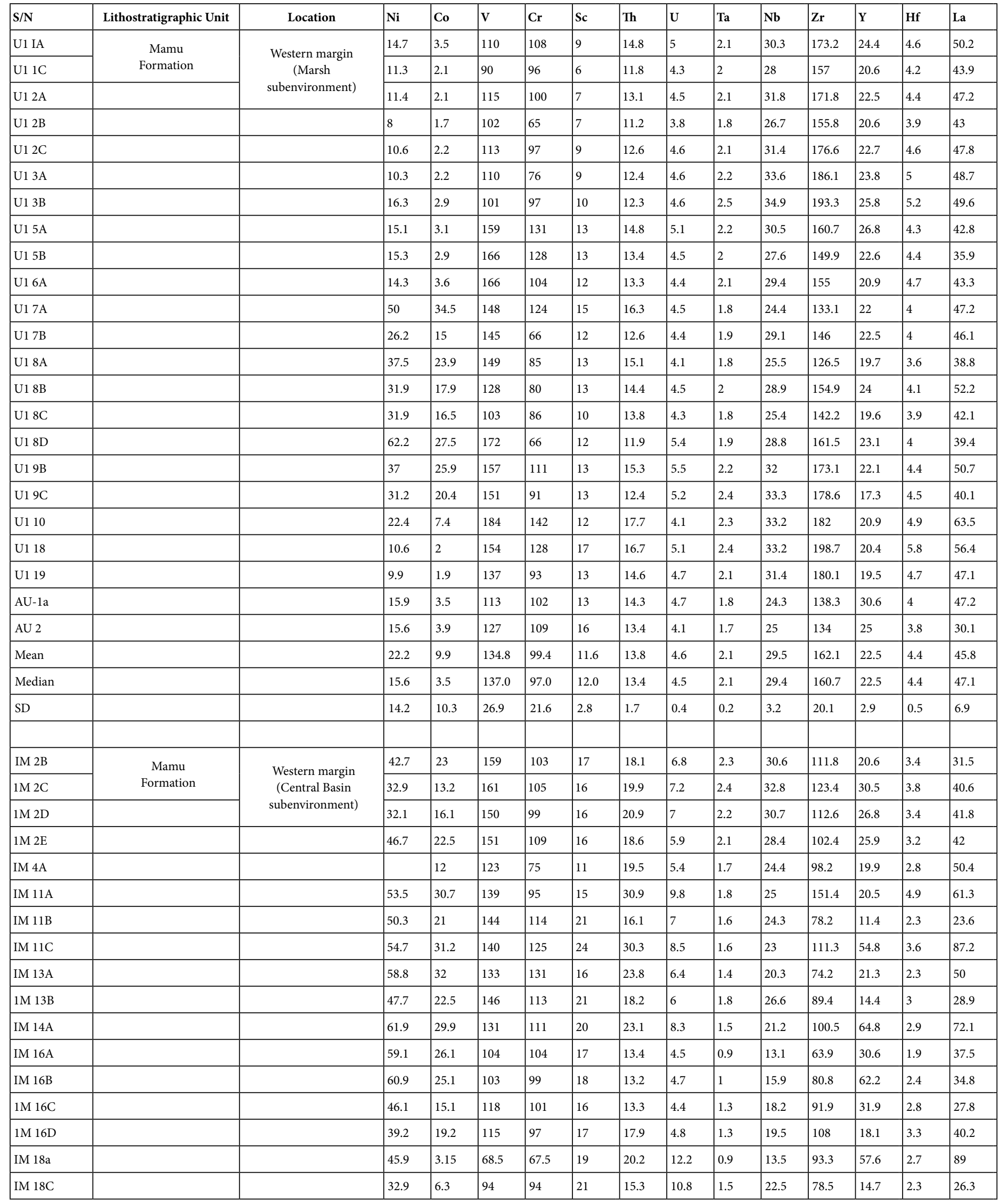


Edegbai Aitalokhai Joel (2020) Differentiation of Sediment Source Regions in the Southern Benue Trough and Anambra Basin, Nigeria: Insights from Geochemistry of Upper Cretaceous Strata

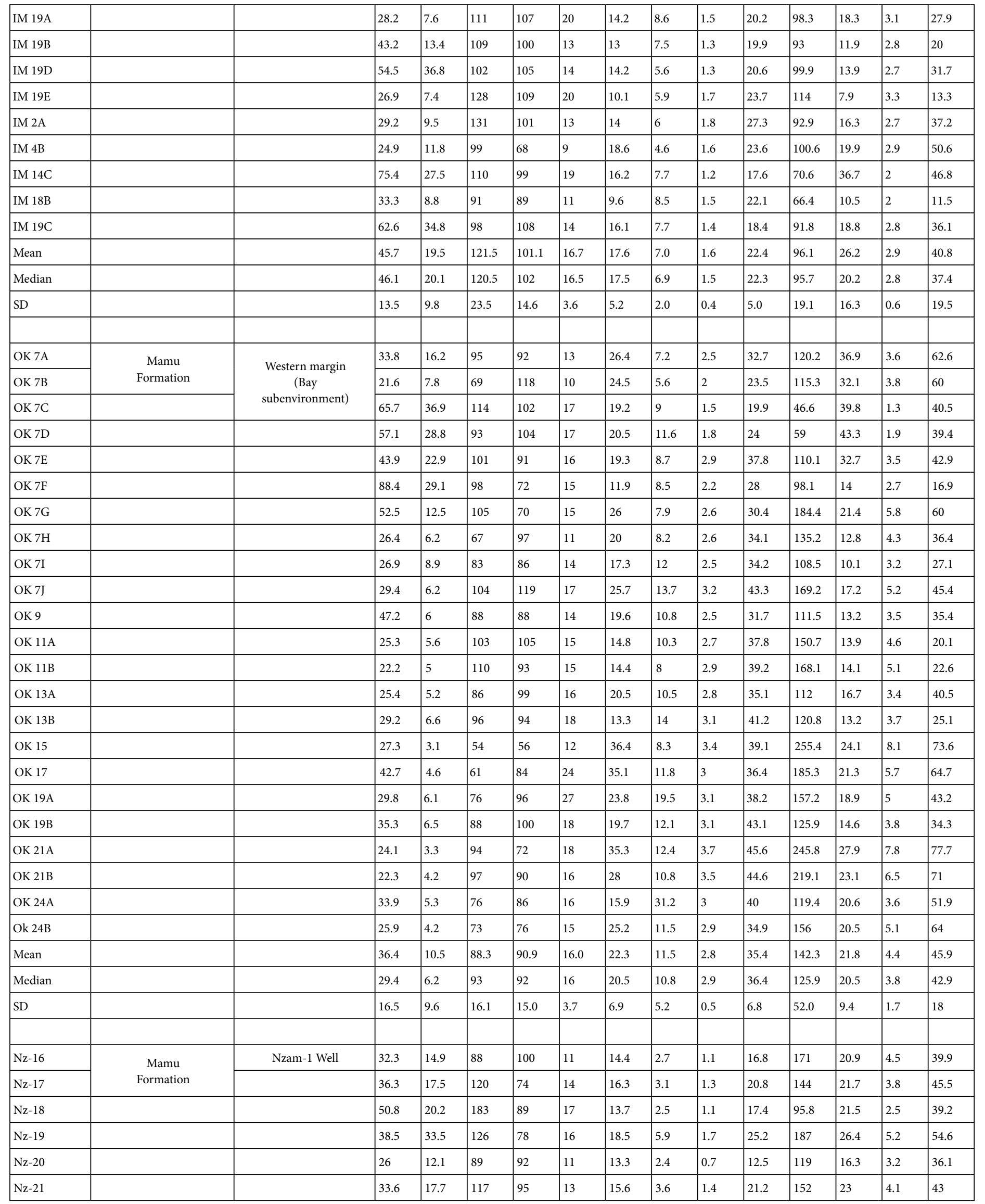


Edegbai Aitalokhai Joel (2020) Differentiation of Sediment Source Regions in the Southern Benue Trough and Anambra Basin, Nigeria: Insights from Geochemistry of Upper Cretaceous Strata

\begin{tabular}{|c|c|c|c|c|c|c|c|c|c|c|c|c|c|c|c|}
\hline $\mathrm{Nz}-22$ & & & 26.1 & 13 & 89 & 89 & 11 & 15.9 & 3 & 1.3 & 19.3 & 156 & 19.1 & 4.2 & 40.1 \\
\hline $\mathrm{Nz}-39$ & & & 36.3 & 25.7 & 121 & 86 & 14 & 11.8 & 4.2 & 1.5 & 20.6 & 173 & 29.1 & 4.4 & 42.5 \\
\hline Mean & & & 35 & 19.3 & 116.6 & 87.9 & 13.4 & 14.9 & 3.4 & 1.26 & $\mid 19.2$ & $\mid 149.7$ & 22.25 & 3.99 & 42.61 \\
\hline Median & & & 35 & 17.6 & 118.5 & 89 & 13.5 & 15 & 3.05 & 1.3 & 19.95 & 154 & 21.6 & 4.15 & 41.3 \\
\hline SD & & & 7.9 & 7.2 & 31.3 & 8.5 & 2.3 & 2.08 & 1.16 & 0.30 & 3.75 & 30.03 & 4.01 & 0.83 & 5.61 \\
\hline ID-3 & \multirow{2}{*}{$\begin{array}{c}\text { Mamu } \\
\text { Formation }\end{array}$} & Idah-1 Well & 3.6 & 4.9 & 13 & 19 & 2 & 8.2 & 1.1 & 0.1 & 1.8 & 23.4 & 5.9 & 0.3 & 18.6 \\
\hline ID-4 & & & 14 & 26.4 & 43 & 53 & 6 & 12.9 & 3.3 & 0.5 & 11.6 & 215 & 17 & 6.4 & 38 \\
\hline ID-5 & & & 14.5 & 7.8 & 53 & 49 & 7 & 7.9 & 2.1 & 0.4 & 8.2 & 70.7 & 12.7 & 2 & 22.1 \\
\hline ID-6 & & & 36 & 22.4 & 109 & 71 & 14 & 12.2 & 6.6 & 1.8 & 26 & 204 & 28.5 & 5.5 & 41 \\
\hline ID-7 & & & 35.9 & 25 & 103 & 66 & 13 & 13.1 & 7.8 & 1.9 & 31.2 & 258 & 35.4 & 6.6 & 47.5 \\
\hline ID-8 & & & 32.7 & 21.7 & 98 & 78 & 13 & 12.5 & 4.9 & 1.5 & 22.1 & 185 & 27.2 & 5.1 & 40.7 \\
\hline ID-9 & & & 33.3 & 17.4 & 87 & 67 & 12 & 11.7 & 4.5 & 1.4 & 19.9 & 179 & 24.6 & 5 & 37.1 \\
\hline ID-10 & & & 19.8 & 16.4 & 62 & 54 & 9 & 10.5 & 4.6 & 1 & 19.5 & 194 & 24.7 & 5.1 & 34.4 \\
\hline ID-11 & & & 27.6 & 16.1 & 76 & 68 & 11 & 11.9 & 5.4 & 1.4 & 24.9 & 220 & 27.1 & 6 & 38.5 \\
\hline ID-12 & & & 29.6 & 24.1 & 72 & 83 & 11 & 12.3 & 4.7 & 1 & 20.2 & 172 & 27.7 & 4.6 & 39.5 \\
\hline ID-13 & & & 28.8 & 21.3 & 90 & 76 & 13 & 14.4 & 6.1 & 1.8 & 25.6 & 226 & 30.5 & 6.3 & 45.9 \\
\hline ID-14 & & & 34 & 23.8 & 103 & 67 & 15 & 15.2 & 6 & 1.9 & 26.9 & 201 & 29.6 & 5.7 & 45.9 \\
\hline ID-15 & & & 33.7 & 21.9 & 96 & 77 & 14 & 15.5 & 5.8 & 1.8 & 26.2 & 206 & 29.6 & 5.8 & 47.6 \\
\hline ID-16 & & & 33.5 & 26.8 & 121 & 83 & 16 & 17.3 & 7.1 & 2.2 & 38 & 293 & 37.2 & 7.6 & 58.6 \\
\hline ID-17 & & & 36.8 & 35 & 92 & 64 & 15 & 19.7 & 7.2 & 2.3 & 32.5 & 237 & 30.7 & 7.3 & 56.8 \\
\hline ID- 18 & & & 41 & 23.4 & 113 & 67 & 16 & 17.6 & 7.9 & 0.6 & 18.2 & 194 & 33.4 & 5.6 & 53.1 \\
\hline ID-19 & & & 33.6 & 23.8 & 84 & 54 & 14 & 18.5 & 6.3 & 1.9 & 26.3 & 188 & 27.5 & 5.6 & 52.3 \\
\hline ID-20 & & & 43.3 & 29.6 & 98 & 62 & 15 & 16.6 & 6.5 & 1.8 & 24.6 & 199 & 27.6 & 5.8 & 47.1 \\
\hline ID-21 & & & 45.7 & 21.5 & 118 & 84 & 16 & 13.3 & 4.6 & 1.4 & 18.7 & 128 & 28.2 & 3.8 & 42.8 \\
\hline ID-22 & & & 41.3 & 20.5 & 113 & 78 & 17 & $\mid 17.4$ & 4.8 & 1.4 & $\mid$\begin{tabular}{|l|}
$\mid 19.1$ \\
\end{tabular} & 138 & 27.3 & 4 & 47.1 \\
\hline ID-23 & & & 43 & 22.4 & 113 & 71 & 15 & 13 & 6.3 & 1.5 & 22.6 & 157 & 39.2 & 4.4 & 47.9 \\
\hline Mean & & & 31.51 & 21.5 & 88.43 & $|66.24|$ & 12.57 & 13.89 & 5.41 & 1.41 & 22.1 & 185.2 & 27.22 & 5.17 & 42.97 \\
\hline Median & & & 33.6 & 22.4 & 96 & 67 & 14 & $\mid$\begin{tabular}{|l|} 
\\
\end{tabular} & 5.8 & 1.5 & 22.6 & 194 & 27.7 & 5.6 & 45.9 \\
\hline SD & & & 10.7 & 6.60 & 27.39 & 14.90 & 3.80 & 3.19 & 1.74 & 0.604 & 8.09 & 59.39 & 7.64 & 1.67 & 9.86 \\
\hline OW-10 & \multirow{2}{*}{$\begin{array}{c}\text { Mamu } \\
\text { Formation }\end{array}$} & Owan-1 Well & 7.3 & 32.6 & 37 & 35 & 3 & 13 & 3 & 0.5 & 9.5 & 196 & 10.3 & 6.2 & 27.2 \\
\hline OW-11 & & & 35.9 & 30.9 & 50 & 82 & 18 & 24 & 8.5 & $<0.1$ & 1.5 & 114 & 40.4 & 4.5 & 66.4 \\
\hline OW-12 & & & 4.6 & 11.6 & 10 & 36 & 5 & 13.7 & 3 & $\mid<0.1$ & 0.4 & 120 & 14.6 & 3.6 & 27.9 \\
\hline OW-13 & & & 4.8 & 23 & 19 & 29 & 4 & 9 & 1.9 & $\mid<0.1$ & 1 & 96.1 & 9.8 & 2 & 21.3 \\
\hline OW-14 & & & 21 & 15.4 & 91 & 82 & 11 & 18.8 & 4.2 & 1.3 & 21.7 & 228 & 24.2 & 6.8 & 47.8 \\
\hline OW-15 & & & 18.7 & 41.7 & 71 & 82 & 9 & 18.6 & 4.4 & 0.2 & 7.8 & 228 & 27.3 & 6.1 & 49.3 \\
\hline OW-16 & & & 12.2 & 29.4 & 43 & 38 & 5 & 10.6 & 3.2 & 0.1 & 4.1 & 144 & 12.4 & 4.1 & 29.1 \\
\hline Mean & & & 14.93 & 26.4 & 45.86 & 54.86 & 7.86 & 15.38 & 4.03 & 0.53 & 6.57 & 160.9 & 19.86 & 4.76 & 38.43 \\
\hline Median & & & 12.2 & 29.4 & 43 & 38 & 5 & 13.7 & 3.2 & 0.35 & 4.1 & 144 & 14.6 & 4.5 & 29.1 \\
\hline SD & & & 11.29 & 10.4 & 28.22 & 25.54 & 5.30 & 5.30 & 2.14 & 0.54 & 7.53 & 55.67 & 11.34 & 1.71 & 16.36 \\
\hline $\mathrm{Am}-3$ & \multirow{2}{*}{$\begin{array}{l}\text { Mamu } \\
\text { Formation }\end{array}$} & \multirow{2}{*}{$\begin{array}{l}\text { Amansiodo-1 } \\
\text { Well }\end{array}$} & 4.5 & 35.9 & 12 & 11 & 1 & 1.8 & 0.6 & $<0.1$ & 1.2 & 11.5 & 4 & 0.4 & 6.8 \\
\hline Am-4 & & & 5.3 & 35.7 & 14 & 16 & 1 & 1.6 & 0.6 & $\mid<0.1$ & 1.5 & 11.5 & 4.6 & 0.3 & 7.1 \\
\hline Am-5 & & & 6.4 & 51.3 & 22 & 21 & 2 & 2.3 & 0.8 & $\mid<0.1$ & 1.6 & 24.6 & 4.9 & 0.7 & 7.9 \\
\hline Am-6 & & & 2.5 & 35.1 & 10 & 10 & 1 & 1.8 & 0.8 & $<0.1$ & 2 & 50.5 & 3.3 & 0.6 & 5.8 \\
\hline
\end{tabular}


Edegbai Aitalokhai Joel (2020) Differentiation of Sediment Source Regions in the Southern Benue Trough and Anambra Basin, Nigeria: Insights from Geochemistry of Upper Cretaceous Strata

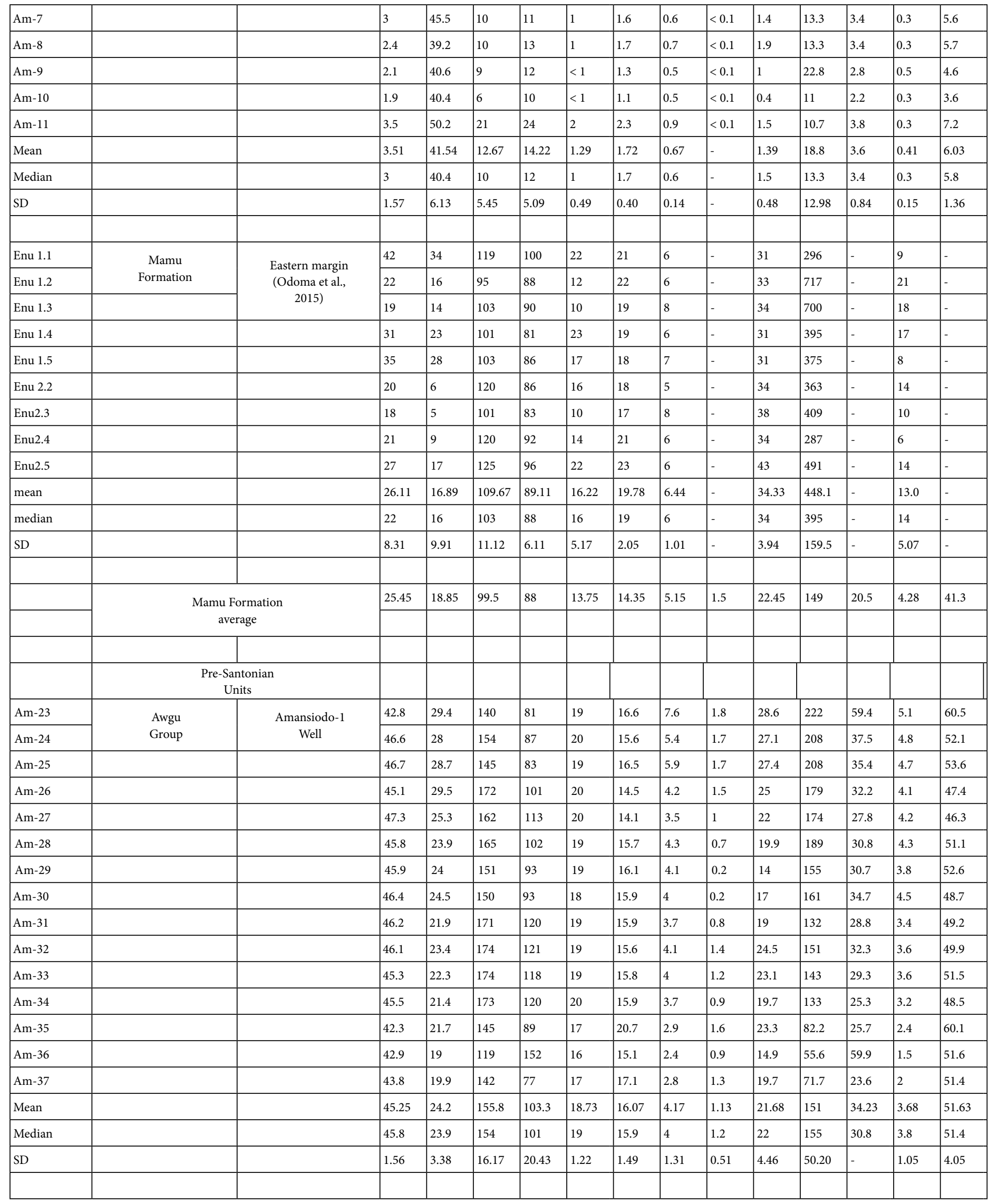


Edegbai Aitalokhai Joel (2020) Differentiation of Sediment Source Regions in the Southern Benue Trough and Anambra Basin, Nigeria: Insights from Geochemistry of Upper Cretaceous Strata

\begin{tabular}{|c|c|c|c|c|c|c|c|c|c|c|c|c|c|c|c|}
\hline Ak-3 & \multirow{2}{*}{$\begin{array}{l}\text { Awgu } \\
\text { Group }\end{array}$} & Akukwa-II Well & 48.1 & 16.5 & 168 & 89 & 15 & 6.6 & 2.3 & 1 & 16.1 & 121 & 21.6 & 2.9 & 14.6 \\
\hline Ak-4 & & & 56.6 & 22.3 & 193 & 110 & 16 & 4.1 & 2.9 & 0.9 & 15.4 & 97.3 & 21.7 & 2.4 & 6.5 \\
\hline Ak-5 & & & 50.6 & 20 & 159 & 109 & 17 & 7.3 & 2.9 & 1.3 & 22 & 146 & 28.9 & 3.5 & 14.5 \\
\hline Ak-6 & & & 53.5 & 22.7 & 171 & 60 & 16 & 3.7 & 2.6 & 1 & 16.5 & 104 & 24.5 & 2.5 & 8.8 \\
\hline Ak-7 & & & 47.2 & 21.8 & 137 & 53 & 15 & 4 & 3 & 1.1 & 18.6 & 137 & 25.5 & 3.3 & 12.2 \\
\hline Ak-8 & & & 55.6 & 25.3 & 182 & 66 & 17 & 3 & 3.2 & 1.1 & 19.3 & 124 & 24 & 3 & 13 \\
\hline Ak-9 & & & 47.9 & 19.8 & 160 & 65 & 16 & 5.7 & 2.8 & 1.1 & 17.5 & 117 & 24.8 & 2.9 & 17.4 \\
\hline Ak-10 & & & 20.9 & 17.8 & 87 & 42 & 8 & 7.4 & 1.6 & 0.6 & 9.6 & 66.8 & 12.4 & 1.6 & 23.5 \\
\hline Ak-11 & & & 46.6 & 19.8 & 157 & 69 & 17 & 3.8 & 3.4 & 1.3 & 21.7 & 129 & 24.5 & 3.2 & 14.7 \\
\hline Mean & & & 47.44 & 20.7 & 157.1 & 73.67 & 15.22 & 5.07 & 2.74 & 1.04 & 17.41 & 115.8 & 23.1 & 2.81 & 13.91 \\
\hline Median & & & 48.1 & 20 & 160 & 66 & 16 & 4.1 & 2.9 & 1.1 & 17.5 & 121 & 24.5 & 2.9 & 14.5 \\
\hline SD & & & 10.62 & 2.67 & 30.72 & 23.92 & 2.82 & 1.7 & 0.53 & 0.21 & 3.74 & 23.75 & 4.55 & 0.58 & 4.88 \\
\hline Ak-12 & \multirow{2}{*}{$\begin{array}{c}\text { Eze-Aku } \\
\text { Group }\end{array}$} & Akukwa-II Well & 53.7 & 22 & 165 & 62 & 17 & 2.8 & 3.3 & 1.2 & 20.3 & 129 & 25.3 & 3.1 & 12.2 \\
\hline Ak-13 & & & 46.6 & 20.6 & 167 & 64 & 16 & 2.4 & 3.1 & 1.1 & 19.3 & 117 & 27.8 & 2.8 & 10.8 \\
\hline Ak-14 & & & 29.1 & 20.1 & 107 & 81 & 16 & 11.7 & 2.6 & 0.1 & 7.8 & 82.8 & 17.7 & 2.2 & 37.7 \\
\hline Ak-15 & & & 43.9 & 17.1 & 161 & 58 & 15 & 1.8 & 2.8 & 1.2 & 21.4 & 132 & 25.1 & 3.2 & 11.1 \\
\hline Ak-16 & & & 39.8 & 17.7 & 157 & 63 & 14 & 2.7 & 2.6 & 1.1 & 18.4 & 105 & 24.2 & 2.6 & 10.3 \\
\hline Ak-17 & & & 45.1 & 22.1 & 179 & 101 & 16 & 9.7 & 3.5 & 1.3 & 21.2 & 108 & 23.1 & 2.8 & 21.8 \\
\hline Ak-18 & & & 40.2 & 17.6 & 132 & 65 & 14 & 3.2 & 2.5 & 1.1 & 18.6 & 79.7 & 20.8 & 2.1 & 10.8 \\
\hline Ak-19 & & & 66.5 & 28.5 & 226 & 77 & 13 & 5.7 & 4.2 & 1 & 16 & 73.2 & 21.6 & 1.9 & 17.7 \\
\hline Ak-20 & & & 45.2 & 20.3 & 168 & 67 & 14 & 4.2 & 2.6 & 1.1 & 18.7 & 69.4 & 20.9 & 1.8 & 13.1 \\
\hline Ak-21 & & & 44.1 & 22 & 145 & 65 & 13 & 5.2 & 2.7 & 1.1 & 19.2 & 83.3 & 20.8 & 2.2 & 14.9 \\
\hline Ak-22 & & & 39.1 & 17.5 & 157 & 81 & 13 & 8 & 2.9 & 1.2 & 18.9 & 77 & 20.7 & 2 & 20 \\
\hline Ak-23 & & & 43.9 & 19 & 96 & 65 & 10 & 5.2 & 1.8 & 0.7 & 12.8 & 59.9 & 23.9 & 1.3 & 12.2 \\
\hline Ak-24 & & & 43.9 & 27.3 & 149 & 102 & 16 & 15.9 & 2.6 & 1.3 & 22 & 45.6 & 22.3 & 1.2 & 39.2 \\
\hline Ak-25 & & & 43.7 & 20.7 & 141 & 101 & 16 & 17.1 & 2.6 & 1.4 & 21.2 & 43.7 & 21 & 1.2 & 50.2 \\
\hline Ak-26 & & & 43.5 & 22.2 & 142 & 102 & 16 & 15.4 & 2.6 & 1.3 & 21.2 & 41.1 & 21.6 & 1.1 & 50.2 \\
\hline Ak-27 & & & 43.2 & 19.8 & 119 & 80 & 14 & 3.2 & 2.3 & 1 & 17.9 & 37.4 & 19.6 & 1.1 & 11.3 \\
\hline Ak-28 & & & 41.7 & 21.8 & 138 & 81 & 14 & 5.6 & 2.6 & 1.3 & 20.1 & 41 & 18.5 & 1.1 & 17.8 \\
\hline Ak-29 & & & 37.3 & 30.5 & 118 & 67 & 13 & 2.7 & 2.3 & 0.9 & 16.5 & 35.7 & 19.8 & 1 & 9.5 \\
\hline Ak-30 & & & 48.9 & 16.9 & 134 & 89 & 14 & 3 & 2.5 & 1.1 & 17.8 & 36.7 & 20.3 & 1 & 8.5 \\
\hline Ak-31 & & & 37.7 & 17 & 115 & 68 & 13 & 3 & 2.4 & 1 & 15.3 & 33.2 & 18.1 & 0.9 & 9.9 \\
\hline Ak-32 & & & 44.6 & 23.4 & 128 & 67 & 13 & 2.9 & 2.5 & 1 & 16.2 & 32.3 & 19 & 0.9 & 9.6 \\
\hline Mean & & & 43.89 & 21.1 & 145 & 76.48 & 14.29 & 6.26 & 2.71 & 1.07 & 18.13 & 69.67 & 21.53 & 1.79 & 18.99 \\
\hline Median & & & 43.9 & 20.6 & 142 & 68 & 14 & 4.2 & 2.6 & 1.1 & 18.7 & 69.4 & 20.9 & 1.8 & 12.2 \\
\hline SD & & & 7.08 & 3.78 & 28.72 & 14.77 & 1.65 & 4.84 & 0.49 & 0.27 & 3.32 & 33.08 & 2.60 & 0.78 & 13.35 \\
\hline UCC & & & 44 & 17 & 107 & 83 & 13.6 & 10.7 & 2.8 & 1.0 & 12 & 190 & 22 & 5.8 & 30 \\
\hline
\end{tabular}


Edegbai Aitalokhai Joel (2020) Differentiation of Sediment Source Regions in the Southern Benue Trough and Anambra Basin, Nigeria: Insights from Geochemistry of Upper Cretaceous Strata

Appendix 1c

\begin{tabular}{|c|c|c|c|c|c|c|c|c|c|c|c|c|c|c|c|}
\hline $\mathbf{S} / \mathbf{N}$ & Lithostratigraphic Unit & Location & $\mathrm{Ni}$ & Co & V & $\mathrm{Cr}$ & Sc & Th & $\mathbf{U}$ & Ta & $\mathrm{Nb}$ & $\mathrm{Zr}$ & $\mathbf{Y}$ & Hf & $\mathbf{L a}$ \\
\hline U1 IA & \multirow{2}{*}{$\begin{array}{l}\text { Mamu } \\
\text { Formation }\end{array}$} & \multirow{3}{*}{$\begin{array}{l}\text { Western margin } \\
\text { (Marsh } \\
\text { subenvironment) }\end{array}$} & 14.7 & 3.5 & 110 & 108 & 9 & 14.8 & 5 & 2.1 & 30.3 & 173.2 & 24.4 & 4.6 & 50.2 \\
\hline U1 1C & & & 11.3 & 2.1 & 90 & 96 & 6 & 11.8 & 4.3 & 2 & 28 & 157 & 20.6 & 4.2 & 43.9 \\
\hline U1 2A & & & 11.4 & 2.1 & 115 & 100 & 7 & 13.1 & 4.5 & 2.1 & 31.8 & 171.8 & 22.5 & 4.4 & 47.2 \\
\hline U1 2B & & & 8 & 1.7 & 102 & 65 & 7 & 11.2 & 3.8 & 1.8 & 26.7 & 155.8 & 20.6 & 3.9 & 43 \\
\hline U1 2C & & & 10.6 & 2.2 & 113 & 97 & 9 & 12.6 & 4.6 & 2.1 & 31.4 & 176.6 & 22.7 & 4.6 & 47.8 \\
\hline U1 3A & & & 10.3 & 2.2 & 110 & 76 & 9 & 12.4 & 4.6 & 2.2 & 33.6 & 186.1 & 23.8 & 5 & 48.7 \\
\hline U1 3B & & & 16.3 & 2.9 & 101 & 97 & 10 & 12.3 & 4.6 & 2.5 & 34.9 & 193.3 & 25.8 & 5.2 & 49.6 \\
\hline U1 5A & & & 15.1 & 3.1 & 159 & 131 & 13 & 14.8 & 5.1 & 2.2 & 30.5 & 160.7 & 26.8 & 4.3 & 42.8 \\
\hline U1 5B & & & 15.3 & 2.9 & 166 & 128 & 13 & 13.4 & 4.5 & 2 & 27.6 & 149.9 & 22.6 & 4.4 & 35.9 \\
\hline U1 6A & & & 14.3 & 3.6 & 166 & 104 & 12 & 13.3 & 4.4 & 2.1 & 29.4 & 155 & 20.9 & 4.7 & 43.3 \\
\hline U1 7A & & & 50 & 34.5 & 148 & 124 & 15 & 16.3 & 4.5 & 1.8 & 24.4 & 133.1 & 22 & 4 & 47.2 \\
\hline U1 7B & & & 26.2 & 15 & 145 & 66 & 12 & 12.6 & 4.4 & 1.9 & 29.1 & 146 & 22.5 & 4 & 46.1 \\
\hline U1 8A & & & 37.5 & 23.9 & 149 & 85 & 13 & 15.1 & 4.1 & 1.8 & 25.5 & 126.5 & 19.7 & 3.6 & 38.8 \\
\hline U1 8B & & & 31.9 & 17.9 & 128 & 80 & 13 & 14.4 & 4.5 & 2 & 28.9 & 154.9 & 24 & 4.1 & 52.2 \\
\hline U1 8C & & & 31.9 & 16.5 & 103 & 86 & 10 & 13.8 & 4.3 & 1.8 & 25.4 & 142.2 & 19.6 & 3.9 & 42.1 \\
\hline U1 8D & & & 62.2 & 27.5 & 172 & 66 & 12 & 11.9 & 5.4 & 1.9 & 28.8 & 161.5 & 23.1 & 4 & 39.4 \\
\hline U1 9B & & & 37 & 25.9 & 157 & 111 & 13 & 15.3 & 5.5 & 2.2 & 32 & 173.1 & 22.1 & 4.4 & 50.7 \\
\hline U19C & & & 31.2 & 20.4 & 151 & 91 & 13 & 12.4 & 5.2 & 2.4 & 33.3 & 178.6 & 17.3 & 4.5 & 40.1 \\
\hline U1 10 & & & 22.4 & 7.4 & 184 & 142 & 12 & 17.7 & 4.1 & 2.3 & 33.2 & 182 & 20.9 & 4.9 & 63.5 \\
\hline U1 18 & & & 10.6 & 2 & 154 & 128 & 17 & 16.7 & 5.1 & 2.4 & 33.2 & 198.7 & 20.4 & 5.8 & 56.4 \\
\hline U1 19 & & & 9.9 & 1.9 & 137 & 93 & 13 & 14.6 & 4.7 & 2.1 & 31.4 & 180.1 & 19.5 & 4.7 & 47.1 \\
\hline AU-1a & & & 15.9 & 3.5 & 113 & 102 & 13 & 14.3 & 4.7 & 1.8 & 24.3 & 138.3 & 30.6 & 4 & 47.2 \\
\hline AU 2 & & & 15.6 & 3.9 & 127 & 109 & 16 & 13.4 & 4.1 & 1.7 & 25 & 134 & 25 & 3.8 & 30.1 \\
\hline Mean & & & 22.2 & 9.9 & 134.8 & 99.4 & 11.6 & 13.8 & 4.6 & 2.1 & 29.5 & 162.1 & 22.5 & 4.4 & 45.8 \\
\hline Median & & & 15.6 & 3.5 & 137.0 & 97.0 & 12.0 & 13.4 & 4.5 & 2.1 & 29.4 & 160.7 & 22.5 & 4.4 & 47.1 \\
\hline SD & & & 14.2 & 10.3 & 26.9 & 21.6 & 2.8 & 1.7 & 0.4 & 0.2 & 3.2 & 20.1 & 2.9 & 0.5 & 6.9 \\
\hline IM 2B & \multirow{2}{*}{$\begin{array}{c}\text { Mamu } \\
\text { Formation }\end{array}$} & \multirow{3}{*}{$\begin{array}{l}\text { Western margin } \\
\text { (Central Basin } \\
\text { subenvironment) }\end{array}$} & 42.7 & 23 & 159 & 103 & 17 & 18.1 & 6.8 & 2.3 & 30.6 & 111.8 & 20.6 & 3.4 & 31.5 \\
\hline $1 \mathrm{M} 2 \mathrm{C}$ & & & 32.9 & 13.2 & 161 & 105 & 16 & 19.9 & 7.2 & 2.4 & 32.8 & 123.4 & 30.5 & 3.8 & 40.6 \\
\hline $1 \mathrm{M} 2 \mathrm{D}$ & & & 32.1 & 16.1 & 150 & 99 & 16 & 20.9 & 7 & 2.2 & 30.7 & 112.6 & 26.8 & 3.4 & 41.8 \\
\hline $1 \mathrm{M} 2 \mathrm{E}$ & & & 46.7 & 22.5 & 151 & 109 & 16 & 18.6 & 5.9 & 2.1 & 28.4 & 102.4 & 25.9 & 3.2 & 42 \\
\hline $\mathrm{IM} 4 \mathrm{~A}$ & & & & 12 & 123 & 75 & 11 & 19.5 & 5.4 & 1.7 & 24.4 & 98.2 & 19.9 & 2.8 & 50.4 \\
\hline IM 11A & & & 53.5 & 30.7 & 139 & 95 & 15 & 30.9 & 9.8 & 1.8 & 25 & 151.4 & 20.5 & 4.9 & 61.3 \\
\hline IM 11B & & & 50.3 & 21 & 144 & 114 & 21 & 16.1 & 7 & 1.6 & 24.3 & 78.2 & 11.4 & 2.3 & 23.6 \\
\hline IM 11C & & & 54.7 & 31.2 & 140 & 125 & 24 & 30.3 & 8.5 & 1.6 & 23 & 111.3 & 54.8 & 3.6 & 87.2 \\
\hline IM 13A & & & 58.8 & 32 & 133 & 131 & 16 & 23.8 & 6.4 & 1.4 & 20.3 & 74.2 & 21.3 & 2.3 & 50 \\
\hline $1 \mathrm{M} 13 \mathrm{~B}$ & & & 47.7 & 22.5 & 146 & 113 & 21 & 18.2 & 6 & 1.8 & 26.6 & 89.4 & 14.4 & 3 & 28.9 \\
\hline IM 14A & & & 61.9 & 29.9 & 131 & 111 & 20 & 23.1 & 8.3 & 1.5 & 21.2 & 100.5 & 64.8 & 2.9 & 72.1 \\
\hline IM 16A & & & 59.1 & 26.1 & 104 & 104 & 17 & 13.4 & 4.5 & 0.9 & 13.1 & 63.9 & 30.6 & 1.9 & 37.5 \\
\hline IM 16B & & & 60.9 & 25.1 & 103 & 99 & 18 & 13.2 & 4.7 & 1 & 15.9 & 80.8 & 62.2 & 2.4 & 34.8 \\
\hline $1 \mathrm{M} 16 \mathrm{C}$ & & & 46.1 & 15.1 & 118 & 101 & 16 & 13.3 & 4.4 & 1.3 & 18.2 & 91.9 & 31.9 & 2.8 & 27.8 \\
\hline $1 \mathrm{M} 16 \mathrm{D}$ & & & 39.2 & 19.2 & 115 & 97 & 17 & 17.9 & 4.8 & 1.3 & 19.5 & 108 & 18.1 & 3.3 & 40.2 \\
\hline IM $18 \mathrm{a}$ & & & 45.9 & 3.15 & 68.5 & 67.5 & 19 & 20.2 & 12.2 & 0.9 & 13.5 & 93.3 & 57.6 & 2.7 & 89 \\
\hline IM $18 \mathrm{C}$ & & & 32.9 & 6.3 & 94 & 94 & 21 & 15.3 & 10.8 & 1.5 & 22.5 & 78.5 & 14.7 & 2.3 & 26.3 \\
\hline
\end{tabular}


Edegbai Aitalokhai Joel (2020) Differentiation of Sediment Source Regions in the Southern Benue Trough and Anambra Basin, Nigeria: Insights from Geochemistry of Upper Cretaceous Strata

\begin{tabular}{|c|c|c|c|c|c|c|c|c|c|c|c|c|c|c|c|}
\hline IM 19A & & & 28.2 & 7.6 & 111 & 107 & 20 & 14.2 & 8.6 & 1.5 & 20.2 & 98.3 & 18.3 & 3.1 & 27.9 \\
\hline IM 19B & & & 43.2 & 13.4 & 109 & 100 & 13 & 13 & 7.5 & 1.3 & 19.9 & 93 & 11.9 & 2.8 & 20 \\
\hline IM 19D & & & 54.5 & 36.8 & 102 & 105 & 14 & 14.2 & 5.6 & 1.3 & 20.6 & 99.9 & 13.9 & 2.7 & 31.7 \\
\hline IM 19E & & & 26.9 & 7.4 & 128 & 109 & 20 & 10.1 & 5.9 & 1.7 & 23.7 & 114 & 7.9 & 3.3 & 13.3 \\
\hline IM 2A & & & 29.2 & 9.5 & 131 & 101 & 13 & 14 & 6 & 1.8 & 27.3 & 92.9 & 16.3 & 2.7 & 37.2 \\
\hline IM 4B & & & 24.9 & 11.8 & 99 & 68 & 9 & 18.6 & 4.6 & 1.6 & 23.6 & 100.6 & 19.9 & 2.9 & 50.6 \\
\hline IM 14C & & & 75.4 & 27.5 & 110 & 99 & 19 & 16.2 & 7.7 & 1.2 & 17.6 & 70.6 & 36.7 & 2 & 46.8 \\
\hline IM 18B & & & 33.3 & 8.8 & 91 & 89 & 11 & 9.6 & 8.5 & 1.5 & 22.1 & 66.4 & 10.5 & 2 & 11.5 \\
\hline IM 19C & & & 62.6 & 34.8 & 98 & 108 & 14 & 16.1 & 7.7 & 1.4 & 18.4 & 91.8 & 18.8 & 2.8 & 36.1 \\
\hline Mean & & & 45.7 & 19.5 & 121.5 & 101.1 & 16.7 & 17.6 & 7.0 & 1.6 & 22.4 & 96.1 & 26.2 & 2.9 & 40.8 \\
\hline Median & & & 46.1 & 20.1 & 120.5 & 102 & 16.5 & 17.5 & 6.9 & 1.5 & 22.3 & 95.7 & 20.2 & 2.8 & 37.4 \\
\hline SD & & & 13.5 & 9.8 & 23.5 & 14.6 & 3.6 & 5.2 & 2.0 & 0.4 & 5.0 & 19.1 & 16.3 & 0.6 & 19.5 \\
\hline OK 7A & \multirow{2}{*}{$\begin{array}{l}\text { Mamu } \\
\text { Formation }\end{array}$} & \multirow{3}{*}{$\begin{array}{l}\text { Western margin } \\
\quad \text { (Bay } \\
\text { subenvironment) }\end{array}$} & 33.8 & 16.2 & 95 & 92 & 13 & 26.4 & 7.2 & 2.5 & 32.7 & 120.2 & 36.9 & 3.6 & 62.6 \\
\hline OK 7B & & & 21.6 & 7.8 & 69 & 118 & 10 & 24.5 & 5.6 & 2 & 23.5 & 115.3 & 32.1 & 3.8 & 60 \\
\hline OK 7C & & & 65.7 & 36.9 & 114 & 102 & 17 & 19.2 & 9 & 1.5 & 19.9 & 46.6 & 39.8 & 1.3 & 40.5 \\
\hline OK 7D & & & 57.1 & 28.8 & 93 & 104 & 17 & 20.5 & 11.6 & 1.8 & 24 & 59 & 43.3 & 1.9 & 39.4 \\
\hline OK 7E & & & 43.9 & 22.9 & 101 & 91 & 16 & 19.3 & 8.7 & 2.9 & 37.8 & $\mid 110.1$ & 32.7 & 3.5 & 42.9 \\
\hline OK 7F & & & 88.4 & 29.1 & 98 & 72 & 15 & 11.9 & 8.5 & 2.2 & 28 & 98.1 & 14 & 2.7 & 16.9 \\
\hline OK 7G & & & 52.5 & 12.5 & 105 & 70 & 15 & 26 & 7.9 & 2.6 & 30.4 & 184.4 & 21.4 & 5.8 & 60 \\
\hline OK 7H & & & 26.4 & 6.2 & 67 & 97 & 11 & 20 & 8.2 & 2.6 & 34.1 & 135.2 & 12.8 & 4.3 & 36.4 \\
\hline OK 7I & & & 26.9 & 8.9 & 83 & 86 & 14 & 17.3 & 12 & 2.5 & 34.2 & 108.5 & $\mid 10.1$ & 3.2 & 27.1 \\
\hline OK 7J & & & 29.4 & 6.2 & 104 & 119 & 17 & 25.7 & 13.7 & 3.2 & 43.3 & 169.2 & 17.2 & 5.2 & 45.4 \\
\hline OK 9 & & & 47.2 & 6 & 88 & 88 & 14 & $\mid 19.6$ & 10.8 & 2.5 & 31.7 & 111.5 & 13.2 & 3.5 & 35.4 \\
\hline OK $11 \mathrm{~A}$ & & & 25.3 & 5.6 & 103 & 105 & 15 & 14.8 & 10.3 & 2.7 & 37.8 & 150.7 & 13.9 & 4.6 & 20.1 \\
\hline OK 11B & & & 22.2 & 5 & 110 & 93 & 15 & 14.4 & 8 & 2.9 & 39.2 & $\mid 168.1$ & 14.1 & 5.1 & 22.6 \\
\hline OK 13A & & & 25.4 & 5.2 & 86 & 99 & 16 & 20.5 & 10.5 & 2.8 & 35.1 & 112 & 16.7 & 3.4 & 40.5 \\
\hline OK 13B & & & 29.2 & 6.6 & 96 & 94 & 18 & 13.3 & 14 & 3.1 & 41.2 & 120.8 & 13.2 & 3.7 & 25.1 \\
\hline OK 15 & & & 27.3 & 3.1 & 54 & 56 & 12 & 36.4 & 8.3 & 3.4 & 39.1 & 255.4 & 24.1 & 8.1 & 73.6 \\
\hline OK 17 & & & 42.7 & 4.6 & 61 & 84 & 24 & 35.1 & 11.8 & 3 & 36.4 & 185.3 & 21.3 & 5.7 & 64.7 \\
\hline OK 19A & & & 29.8 & 6.1 & 76 & 96 & 27 & 23.8 & 19.5 & 3.1 & 38.2 & 157.2 & 18.9 & 5 & 43.2 \\
\hline OK 19B & & & 35.3 & 6.5 & 88 & 100 & 18 & 19.7 & 12.1 & 3.1 & 43.1 & 125.9 & 14.6 & 3.8 & 34.3 \\
\hline OK 21A & & & 24.1 & 3.3 & 94 & 72 & 18 & 35.3 & 12.4 & 3.7 & 45.6 & 245.8 & 27.9 & 7.8 & 77.7 \\
\hline OK 21B & & & 22.3 & 4.2 & 97 & 90 & 16 & 28 & 10.8 & 3.5 & 44.6 & 219.1 & 23.1 & 6.5 & 71 \\
\hline OK 24A & & & 33.9 & 5.3 & 76 & 86 & 16 & 15.9 & 31.2 & 3 & 40 & 119.4 & 20.6 & 3.6 & 51.9 \\
\hline Ok 24B & & & 25.9 & 4.2 & 73 & 76 & 15 & 25.2 & 11.5 & 2.9 & 34.9 & 156 & 20.5 & 5.1 & 64 \\
\hline Mean & & & 36.4 & 10.5 & 88.3 & 90.9 & 16.0 & 22.3 & 11.5 & 2.8 & 35.4 & 142.3 & 21.8 & 4.4 & 45.9 \\
\hline Median & & & 29.4 & 6.2 & 93 & 92 & 16 & 20.5 & 10.8 & 2.9 & 36.4 & 125.9 & 20.5 & 3.8 & 42.9 \\
\hline SD & & & 16.5 & 9.6 & $\mid 16.1$ & 15.0 & 3.7 & 6.9 & 5.2 & 0.5 & 6.8 & 52.0 & 9.4 & 1.7 & 18 \\
\hline $\mathrm{Nz}-16$ & \multirow{2}{*}{$\begin{array}{l}\text { Mamu } \\
\text { Formation }\end{array}$} & Nzam-1 Well & 32.3 & 14.9 & 88 & 100 & 11 & 14.4 & 2.7 & 1.1 & 16.8 & 171 & 20.9 & 4.5 & 39.9 \\
\hline $\mathrm{Nz}-17$ & & & 36.3 & 17.5 & 120 & 74 & 14 & 16.3 & 3.1 & 1.3 & 20.8 & 144 & 21.7 & 3.8 & 45.5 \\
\hline $\mathrm{Nz}-18$ & & & 50.8 & 20.2 & 183 & 89 & 17 & 13.7 & 2.5 & 1.1 & 17.4 & 95.8 & 21.5 & 2.5 & 39.2 \\
\hline $\mathrm{Nz}-19$ & & & 38.5 & 33.5 & 126 & 78 & 16 & 18.5 & 5.9 & 1.7 & 25.2 & 187 & 26.4 & 5.2 & 54.6 \\
\hline $\mathrm{Nz}-20$ & & & 26 & 12.1 & 89 & 92 & 11 & 13.3 & 2.4 & 0.7 & 12.5 & 119 & 16.3 & 3.2 & 36.1 \\
\hline $\mathrm{Nz}-21$ & & & 33.6 & 17.7 & 117 & 95 & 13 & 15.6 & 3.6 & 1.4 & 21.2 & 152 & 23 & 4.1 & 43 \\
\hline
\end{tabular}


Edegbai Aitalokhai Joel (2020) Differentiation of Sediment Source Regions in the Southern Benue Trough and Anambra Basin, Nigeria: Insights from Geochemistry of Upper Cretaceous Strata

\begin{tabular}{|c|c|c|c|c|c|c|c|c|c|c|c|c|c|c|c|}
\hline $\mathrm{Nz}-22$ & & & 26.1 & 13 & 89 & 89 & 11 & 15.9 & 3 & 1.3 & 19.3 & 156 & 19.1 & 4.2 & 40.1 \\
\hline $\mathrm{Nz}-39$ & & & 36.3 & 25.7 & 121 & 86 & 14 & 11.8 & 4.2 & 1.5 & 20.6 & 173 & 29.1 & 4.4 & 42.5 \\
\hline Mean & & & 35 & 19.3 & 116.6 & 87.9 & 13.4 & 14.9 & 3.4 & 1.26 & 19.2 & 149.7 & 22.25 & 3.99 & 42.61 \\
\hline Median & & & 35 & 17.6 & 118.5 & 89 & 13.5 & 15 & 3.05 & 1.3 & 19.95 & 154 & 21.6 & 4.15 & 41.3 \\
\hline SD & & & 7.9 & 7.2 & 31.3 & 8.5 & 2.3 & 2.08 & 1.16 & 0.30 & 3.75 & 30.03 & 4.01 & 0.83 & 5.61 \\
\hline ID-3 & \multirow{2}{*}{$\begin{array}{c}\text { Mamu } \\
\text { Formation }\end{array}$} & Idah-1 Well & 3.6 & 4.9 & 13 & 19 & 2 & 8.2 & 1.1 & 0.1 & 1.8 & 23.4 & 5.9 & 0.3 & 18.6 \\
\hline ID-4 & & & 14 & 26.4 & 43 & 53 & 6 & 12.9 & 3.3 & 0.5 & 11.6 & 215 & 17 & 6.4 & 38 \\
\hline ID-5 & & & 14.5 & 7.8 & 53 & 49 & 7 & 7.9 & 2.1 & 0.4 & 8.2 & 70.7 & 12.7 & 2 & 22.1 \\
\hline ID-6 & & & 36 & 22.4 & 109 & 71 & 14 & 12.2 & 6.6 & 1.8 & 26 & 204 & 28.5 & 5.5 & 41 \\
\hline ID-7 & & & 35.9 & 25 & 103 & 66 & 13 & 13.1 & 7.8 & 1.9 & 31.2 & 258 & 35.4 & 6.6 & 47.5 \\
\hline ID-8 & & & 32.7 & 21.7 & 98 & 78 & 13 & 12.5 & 4.9 & 1.5 & 22.1 & 185 & 27.2 & 5.1 & 40.7 \\
\hline ID-9 & & & 33.3 & 17.4 & 87 & 67 & 12 & 11.7 & 4.5 & 1.4 & 19.9 & 179 & 24.6 & 5 & 37.1 \\
\hline ID-10 & & & $\mid 19.8$ & 16.4 & 62 & 54 & 9 & 10.5 & 4.6 & 1 & 19.5 & 194 & 24.7 & 5.1 & 34.4 \\
\hline ID-11 & & & 27.6 & 16.1 & 76 & 68 & 11 & 11.9 & 5.4 & 1.4 & 24.9 & 220 & 27.1 & 6 & 38.5 \\
\hline ID-12 & & & 29.6 & 24.1 & 72 & 83 & 11 & 12.3 & 4.7 & 1 & 20.2 & 172 & 27.7 & 4.6 & 39.5 \\
\hline ID-13 & & & 28.8 & 21.3 & 90 & 76 & 13 & 14.4 & 6.1 & 1.8 & 25.6 & 226 & 30.5 & 6.3 & 45.9 \\
\hline ID-14 & & & 34 & 23.8 & 103 & 67 & 15 & 15.2 & 6 & 1.9 & 26.9 & 201 & 29.6 & 5.7 & 45.9 \\
\hline ID-15 & & & 33.7 & 21.9 & 96 & 77 & 14 & 15.5 & 5.8 & 1.8 & 26.2 & 206 & 29.6 & 5.8 & 47.6 \\
\hline ID-16 & & & 33.5 & 26.8 & 121 & 83 & 16 & 17.3 & 7.1 & 2.2 & 38 & 293 & 37.2 & 7.6 & 58.6 \\
\hline ID-17 & & & 36.8 & 35 & 92 & 64 & 15 & 19.7 & 7.2 & 2.3 & 32.5 & 237 & 30.7 & 7.3 & 56.8 \\
\hline ID- 18 & & & 41 & 23.4 & 113 & 67 & 16 & 17.6 & 7.9 & 0.6 & 18.2 & 194 & 33.4 & 5.6 & 53.1 \\
\hline ID-19 & & & 33.6 & 23.8 & 84 & 54 & 14 & 18.5 & 6.3 & 1.9 & 26.3 & 188 & 27.5 & 5.6 & 52.3 \\
\hline ID-20 & & & 43.3 & 29.6 & 98 & 62 & 15 & 16.6 & 6.5 & 1.8 & 24.6 & 199 & 27.6 & 5.8 & 47.1 \\
\hline ID-21 & & & 45.7 & 21.5 & 118 & 84 & 16 & 13.3 & 4.6 & 1.4 & 18.7 & 128 & 28.2 & 3.8 & 42.8 \\
\hline ID-22 & & & 41.3 & 20.5 & 113 & 78 & 17 & 17.4 & 4.8 & 1.4 & 19.1 & 138 & 27.3 & 4 & 47.1 \\
\hline ID-23 & & & 43 & 22.4 & 113 & 71 & 15 & 13 & 6.3 & 1.5 & 22.6 & 157 & 39.2 & 4.4 & 47.9 \\
\hline Mean & & & 31.51 & 21.5 & 88.43 & 66.24 & 12.57 & 13.89 & 5.41 & 1.41 & 22.1 & 185.2 & 27.22 & 5.17 & 42.97 \\
\hline Median & & & 33.6 & 22.4 & 96 & 67 & 14 & $\mid 13.1$ & 5.8 & 1.5 & 22.6 & 194 & 27.7 & 5.6 & 45.9 \\
\hline SD & & & 10.7 & 6.60 & 27.39 & 14.90 & 3.80 & 3.19 & 1.74 & 0.604 & 8.09 & 59.39 & 7.64 & 1.67 & 9.86 \\
\hline OW-10 & \multirow{2}{*}{$\begin{array}{c}\text { Mamu } \\
\text { Formation }\end{array}$} & Owan-1 Well & 7.3 & 32.6 & 37 & 35 & 3 & 13 & 3 & 0.5 & 9.5 & 196 & 10.3 & 6.2 & 27.2 \\
\hline OW-11 & & & 35.9 & 30.9 & 50 & 82 & 18 & 24 & 8.5 & $<0.1$ & 1.5 & 114 & 40.4 & 4.5 & 66.4 \\
\hline OW-12 & & & 4.6 & 11.6 & 10 & 36 & 5 & 13.7 & 3 & $<0.1$ & 0.4 & 120 & 14.6 & 3.6 & 27.9 \\
\hline OW-13 & & & 4.8 & 23 & 19 & 29 & 4 & 9 & 1.9 & $<0.1$ & 1 & 96.1 & 9.8 & 2 & 21.3 \\
\hline OW-14 & & & 21 & 15.4 & 91 & 82 & 11 & 18.8 & 4.2 & 1.3 & 21.7 & 228 & 24.2 & 6.8 & 47.8 \\
\hline OW-15 & & & 18.7 & 41.7 & 71 & 82 & 9 & 18.6 & 4.4 & 0.2 & 7.8 & 228 & 27.3 & 6.1 & 49.3 \\
\hline OW-16 & & & 12.2 & 29.4 & 43 & 38 & 5 & 10.6 & 3.2 & 0.1 & 4.1 & 144 & 12.4 & 4.1 & 29.1 \\
\hline Mean & & & 14.93 & 26.4 & 45.86 & 54.86 & 7.86 & 15.38 & 4.03 & 0.53 & 6.57 & 160.9 & 19.86 & 4.76 & 38.43 \\
\hline Median & & & 12.2 & 29.4 & 43 & 38 & 5 & 13.7 & 3.2 & 0.35 & 4.1 & 144 & 14.6 & 4.5 & 29.1 \\
\hline SD & & & 11.29 & 10.4 & 28.22 & 25.54 & 5.30 & 5.30 & 2.14 & 0.54 & 7.53 & 55.67 & 11.34 & 1.71 & 16.36 \\
\hline $\mathrm{Am}-3$ & \multirow{2}{*}{$\begin{array}{l}\text { Mamu } \\
\text { Formation }\end{array}$} & \multirow{2}{*}{$\begin{array}{l}\text { Amansiodo-1 } \\
\text { Well }\end{array}$} & 4.5 & 35.9 & 12 & 11 & 1 & 1.8 & 0.6 & $<0.1$ & 1.2 & 11.5 & 4 & 0.4 & 6.8 \\
\hline Am-4 & & & 5.3 & 35.7 & 14 & 16 & 1 & 1.6 & 0.6 & $<0.1$ & 1.5 & 11.5 & 4.6 & 0.3 & 7.1 \\
\hline Am-5 & & & 6.4 & 51.3 & 22 & 21 & 2 & 2.3 & 0.8 & $<0.1$ & 1.6 & 24.6 & 4.9 & 0.7 & 7.9 \\
\hline Am-6 & & & 2.5 & 35.1 & 10 & 10 & 1 & 1.8 & 0.8 & $<0.1$ & 2 & 50.5 & 3.3 & 0.6 & 5.8 \\
\hline
\end{tabular}


Edegbai Aitalokhai Joel (2020) Differentiation of Sediment Source Regions in the Southern Benue Trough and Anambra Basin, Nigeria: Insights from Geochemistry of Upper Cretaceous Strata

\begin{tabular}{|c|c|c|c|c|c|c|c|c|c|c|c|c|c|c|c|}
\hline $\mathrm{Am}-7$ & & & 3 & 45.5 & 10 & 11 & 1 & 1.6 & 0.6 & $<0.1$ & 1.4 & 13.3 & 3.4 & 0.3 & 5.6 \\
\hline Am-8 & & & 2.4 & 39.2 & 10 & 13 & 1 & 1.7 & 0.7 & $<0.1$ & 1.9 & 13.3 & 3.4 & 0.3 & 5.7 \\
\hline Am-9 & & & 2.1 & 40.6 & 9 & 12 & $<1$ & 1.3 & 0.5 & $<0.1$ & 1 & 22.8 & 2.8 & 0.5 & 4.6 \\
\hline Am-10 & & & 1.9 & 40.4 & 6 & 10 & $<1$ & 1.1 & 0.5 & $<0.1$ & 0.4 & 11 & 2.2 & 0.3 & 3.6 \\
\hline Am-11 & & & 3.5 & 50.2 & 21 & 24 & 2 & 2.3 & 0.9 & $<0.1$ & 1.5 & 10.7 & 3.8 & 0.3 & 7.2 \\
\hline Mean & & & 3.51 & 41.54 & 12.67 & 14.22 & 1.29 & 1.72 & 0.67 & - & 1.39 & 18.8 & 3.6 & 0.41 & 6.03 \\
\hline Median & & & 3 & 40.4 & 10 & 12 & 1 & 1.7 & 0.6 & - & 1.5 & 13.3 & 3.4 & 0.3 & 5.8 \\
\hline SD & & & 1.57 & 6.13 & 5.45 & 5.09 & 0.49 & 0.40 & 0.14 & - & 0.48 & 12.98 & 0.84 & 0.15 & 1.36 \\
\hline Enu 1.1 & Mamu & & 42 & 34 & 119 & 100 & 22 & 21 & 6 & - & 31 & 296 & - & 9 & - \\
\hline Enu 1.2 & Formation & (Odoma et al., & 22 & 16 & 95 & 88 & 12 & 22 & 6 & - & 33 & 717 & - & 21 & - \\
\hline Enu 1.3 & & 2015) & 19 & 14 & 103 & 90 & 10 & 19 & 8 & - & 34 & 700 & - & 18 & - \\
\hline Enu 1.4 & & & 31 & 23 & 101 & 81 & 23 & 19 & 6 & - & 31 & 395 & - & 17 & - \\
\hline Enu 1.5 & & & 35 & 28 & 103 & 86 & 17 & 18 & 7 & - & 31 & 375 & - & 8 & - \\
\hline Enu 2.2 & & & 20 & 6 & 120 & 86 & 16 & 18 & 5 & - & 34 & 363 & - & 14 & - \\
\hline Enu2.3 & & & 18 & 5 & 101 & 83 & 10 & 17 & 8 & - & 38 & 409 & - & 10 & - \\
\hline Enu2.4 & & & 21 & 9 & 120 & 92 & 14 & 21 & 6 & - & 34 & 287 & - & 6 & - \\
\hline Enu2.5 & & & 27 & 17 & 125 & 96 & 22 & 23 & 6 & - & 43 & 491 & - & 14 & - \\
\hline mean & & & 26.11 & 16.89 & 109.67 & 89.11 & 16.22 & $\mid 19.78$ & 6.44 & - & 34.33 & 448.1 & - & 13.0 & - \\
\hline median & & & 22 & 16 & 103 & 88 & 16 & 19 & 6 & - & 34 & 395 & - & 14 & - \\
\hline SD & & & 8.31 & 9.91 & 11.12 & 6.11 & 5.17 & 2.05 & 1.01 & - & 3.94 & 159.5 & - & 5.07 & - \\
\hline & \multirow{2}{*}{\multicolumn{2}{|c|}{$\begin{array}{l}\text { Mamu Formation } \\
\text { average }\end{array}$}} & 25.45 & 18.85 & 99.5 & 88 & 13.75 & 14.35 & 5.15 & 1.5 & 22.45 & 149 & 20.5 & 4.28 & 41.3 \\
\hline & & & & & & & & & & & & & & & \\
\hline & \multicolumn{2}{|c|}{$\begin{array}{l}\text { Pre-Santonian } \\
\text { Units }\end{array}$} & & & & & & & & & & & & & \\
\hline $\mathrm{Am}-23$ & \multirow{2}{*}{$\begin{array}{l}\text { Awgu } \\
\text { Group }\end{array}$} & \multirow{2}{*}{$\begin{array}{l}\text { Amansiodo-1 } \\
\text { Well }\end{array}$} & 42.8 & 29.4 & 140 & 81 & 19 & 16.6 & 7.6 & 1.8 & 28.6 & 222 & 59.4 & 5.1 & 60.5 \\
\hline $\mathrm{Am}-24$ & & & 46.6 & 28 & 154 & 87 & 20 & 15.6 & 5.4 & 1.7 & 27.1 & 208 & 37.5 & 4.8 & 52.1 \\
\hline Am-25 & & & 46.7 & 28.7 & 145 & 83 & 19 & 16.5 & 5.9 & 1.7 & 27.4 & 208 & 35.4 & 4.7 & 53.6 \\
\hline Am-26 & & & 45.1 & 29.5 & 172 & 101 & 20 & 14.5 & 4.2 & 1.5 & 25 & 179 & 32.2 & 4.1 & 47.4 \\
\hline Am-27 & & & 47.3 & 25.3 & 162 & 113 & 20 & 14.1 & 3.5 & 1 & 22 & 174 & 27.8 & 4.2 & 46.3 \\
\hline Am-28 & & & 45.8 & 23.9 & 165 & 102 & 19 & 15.7 & 4.3 & 0.7 & 19.9 & 189 & 30.8 & 4.3 & 51.1 \\
\hline Am-29 & & & 45.9 & 24 & 151 & 93 & 19 & 16.1 & 4.1 & 0.2 & 14 & 155 & 30.7 & 3.8 & 52.6 \\
\hline Am-30 & & & 46.4 & 24.5 & 150 & 93 & 18 & 15.9 & 4 & 0.2 & 17 & 161 & 34.7 & 4.5 & 48.7 \\
\hline Am-31 & & & 46.2 & 21.9 & 171 & 120 & 19 & 15.9 & 3.7 & 0.8 & 19 & 132 & 28.8 & 3.4 & 49.2 \\
\hline Am-32 & & & 46.1 & 23.4 & 174 & 121 & 19 & 15.6 & 4.1 & 1.4 & 24.5 & 151 & 32.3 & 3.6 & 49.9 \\
\hline Am-33 & & & 45.3 & 22.3 & 174 & 118 & 19 & 15.8 & 4 & 1.2 & 23.1 & 143 & 29.3 & 3.6 & 51.5 \\
\hline Am-34 & & & 45.5 & 21.4 & 173 & 120 & 20 & 15.9 & 3.7 & 0.9 & 19.7 & 133 & 25.3 & 3.2 & 48.5 \\
\hline Am-35 & & & 42.3 & 21.7 & 145 & 89 & 17 & 20.7 & 2.9 & 1.6 & 23.3 & 82.2 & 25.7 & 2.4 & 60.1 \\
\hline Am-36 & & & 42.9 & 19 & 119 & 152 & 16 & 15.1 & 2.4 & 0.9 & 14.9 & 55.6 & 59.9 & 1.5 & 51.6 \\
\hline Am-37 & & & 43.8 & 19.9 & 142 & 77 & 17 & 17.1 & 2.8 & 1.3 & 19.7 & 71.7 & 23.6 & 2 & 51.4 \\
\hline Mean & & & 45.25 & 24.2 & 155.8 & 103.3 & 18.73 & 16.07 & 4.17 & 1.13 & 21.68 & 151 & 34.23 & 3.68 & 51.63 \\
\hline Median & & & 45.8 & 23.9 & 154 & 101 & 19 & 15.9 & 4 & 1.2 & 22 & 155 & 30.8 & 3.8 & 51.4 \\
\hline SD & & & 1.56 & 3.38 & 16.17 & 20.43 & 1.22 & 1.49 & 1.31 & 0.51 & 4.46 & 50.20 & - & 1.05 & 4.05 \\
\hline
\end{tabular}


Edegbai Aitalokhai Joel (2020) Differentiation of Sediment Source Regions in the Southern Benue Trough and Anambra Basin, Nigeria: Insights from Geochemistry of Upper Cretaceous Strata

\begin{tabular}{|c|c|c|c|c|c|c|c|c|c|c|c|c|c|c|c|}
\hline Ak-3 & \multirow{2}{*}{$\begin{array}{l}\text { Awgu } \\
\text { Group }\end{array}$} & Akukwa-II Well & 48.1 & 16.5 & 168 & 89 & 15 & 6.6 & 2.3 & 1 & 16.1 & 121 & 21.6 & 2.9 & 14.6 \\
\hline Ak-4 & & & 56.6 & 22.3 & 193 & 110 & 16 & 4.1 & 2.9 & 0.9 & 15.4 & 97.3 & 21.7 & 2.4 & 6.5 \\
\hline Ak-5 & & & 50.6 & 20 & 159 & 109 & 17 & 7.3 & 2.9 & 1.3 & 22 & 146 & 28.9 & 3.5 & 14.5 \\
\hline Ak-6 & & & 53.5 & 22.7 & 171 & 60 & 16 & 3.7 & 2.6 & 1 & 16.5 & 104 & 24.5 & 2.5 & 8.8 \\
\hline Ak-7 & & & 47.2 & 21.8 & 137 & 53 & 15 & 4 & 3 & 1.1 & 18.6 & 137 & 25.5 & 3.3 & 12.2 \\
\hline Ak-8 & & & 55.6 & 25.3 & 182 & 66 & 17 & 3 & 3.2 & 1.1 & 19.3 & 124 & 24 & 3 & 13 \\
\hline Ak-9 & & & 47.9 & 19.8 & 160 & 65 & 16 & 5.7 & 2.8 & 1.1 & 17.5 & 117 & 24.8 & 2.9 & 17.4 \\
\hline Ak-10 & & & 20.9 & 17.8 & 87 & 42 & 8 & 7.4 & 1.6 & 0.6 & 9.6 & 66.8 & 12.4 & 1.6 & 23.5 \\
\hline Ak-11 & & & 46.6 & 19.8 & 157 & 69 & 17 & 3.8 & 3.4 & 1.3 & 21.7 & 129 & 24.5 & 3.2 & 14.7 \\
\hline Mean & & & 47.44 & 20.7 & 157.1 & 73.67 & 15.22 & 5.07 & 2.74 & 1.04 & 17.41 & 115.8 & 23.1 & 2.81 & 13.91 \\
\hline Median & & & 48.1 & 20 & 160 & 66 & 16 & 4.1 & 2.9 & 1.1 & 17.5 & 121 & 24.5 & 2.9 & 14.5 \\
\hline SD & & & 10.62 & 2.67 & 30.72 & 23.92 & 2.82 & 1.7 & 0.53 & 0.21 & 3.74 & 23.75 & 4.55 & 0.58 & 4.88 \\
\hline Ak-12 & \multirow{2}{*}{$\begin{array}{l}\text { Eze-Aku } \\
\text { Group }\end{array}$} & Akukwa-II Well & 53.7 & 22 & 165 & 62 & 17 & 2.8 & 3.3 & 1.2 & 20.3 & 129 & 25.3 & 3.1 & 12.2 \\
\hline Ak-13 & & & 46.6 & 20.6 & 167 & 64 & 16 & 2.4 & 3.1 & 1.1 & 19.3 & 117 & 27.8 & 2.8 & 10.8 \\
\hline Ak-14 & & & 29.1 & 20.1 & 107 & 81 & 16 & 11.7 & 2.6 & 0.1 & 7.8 & 82.8 & 17.7 & 2.2 & 37.7 \\
\hline Ak-15 & & & 43.9 & 17.1 & 161 & 58 & 15 & 1.8 & 2.8 & 1.2 & 21.4 & 132 & 25.1 & 3.2 & 11.1 \\
\hline Ak-16 & & & 39.8 & 17.7 & 157 & 63 & 14 & 2.7 & 2.6 & 1.1 & 18.4 & 105 & 24.2 & 2.6 & 10.3 \\
\hline Ak-17 & & & 45.1 & 22.1 & 179 & 101 & 16 & 9.7 & 3.5 & 1.3 & 21.2 & 108 & 23.1 & 2.8 & 21.8 \\
\hline Ak-18 & & & 40.2 & 17.6 & 132 & 65 & 14 & 3.2 & 2.5 & 1.1 & 18.6 & 79.7 & 20.8 & 2.1 & 10.8 \\
\hline Ak-19 & & & 66.5 & 28.5 & 226 & 77 & 13 & 5.7 & 4.2 & 1 & 16 & 73.2 & 21.6 & 1.9 & 17.7 \\
\hline Ak-20 & & & 45.2 & 20.3 & 168 & 67 & 14 & 4.2 & 2.6 & 1.1 & 18.7 & 69.4 & 20.9 & 1.8 & $\mid$\begin{tabular}{|l|} 
\\
\end{tabular} \\
\hline Ak-21 & & & 44.1 & 22 & 145 & 65 & 13 & 5.2 & 2.7 & 1.1 & $\mid 19.2$ & 83.3 & 20.8 & 2.2 & $\mid 14.9$ \\
\hline Ak-22 & & & 39.1 & 17.5 & 157 & 81 & 13 & 8 & 2.9 & 1.2 & 18.9 & 77 & 20.7 & 2 & 20 \\
\hline Ak-23 & & & 43.9 & 19 & 96 & 65 & 10 & 5.2 & 1.8 & 0.7 & 12.8 & 59.9 & 23.9 & 1.3 & 12.2 \\
\hline Ak-24 & & & 43.9 & 27.3 & 149 & 102 & 16 & 15.9 & 2.6 & 1.3 & 22 & 45.6 & 22.3 & 1.2 & 39.2 \\
\hline Ak-25 & & & 43.7 & 20.7 & 141 & 101 & 16 & 17.1 & 2.6 & 1.4 & 21.2 & 43.7 & 21 & 1.2 & 50.2 \\
\hline Ak-26 & & & 43.5 & 22.2 & 142 & 102 & 16 & 15.4 & 2.6 & 1.3 & 21.2 & 41.1 & 21.6 & 1.1 & 50.2 \\
\hline Ak-27 & & & 43.2 & $\mid 19.8$ & 119 & 80 & 14 & 3.2 & 2.3 & 1 & 17.9 & 37.4 & 19.6 & 1.1 & $\mid 11.3$ \\
\hline Ak-28 & & & 41.7 & 21.8 & 138 & 81 & 14 & 5.6 & 2.6 & 1.3 & 20.1 & 41 & 18.5 & 1.1 & 17.8 \\
\hline Ak-29 & & & 37.3 & 30.5 & 118 & 67 & 13 & 2.7 & 2.3 & 0.9 & 16.5 & 35.7 & 19.8 & 1 & 9.5 \\
\hline Ak-30 & & & 48.9 & 16.9 & 134 & 89 & 14 & 3 & 2.5 & 1.1 & 17.8 & 36.7 & 20.3 & 1 & 8.5 \\
\hline Ak-31 & & & 37.7 & 17 & 115 & 68 & 13 & 3 & 2.4 & 1 & 15.3 & 33.2 & 18.1 & 0.9 & 9.9 \\
\hline Ak-32 & & & 44.6 & 23.4 & 128 & 67 & 13 & 2.9 & 2.5 & 1 & 16.2 & 32.3 & 19 & 0.9 & 9.6 \\
\hline Mean & & & 43.89 & 21.1 & 145 & 76.48 & 14.29 & 6.26 & 2.71 & 1.07 & 18.13 & 69.67 & 21.53 & 1.79 & 18.99 \\
\hline Median & & & 43.9 & 20.6 & 142 & 68 & 14 & 4.2 & 2.6 & 1.1 & 18.7 & 69.4 & 20.9 & 1.8 & 12.2 \\
\hline SD & & & 7.08 & 3.78 & 28.72 & 14.77 & 1.65 & 4.84 & 0.49 & 0.27 & 3.32 & 33.08 & 2.60 & 0.78 & 13.35 \\
\hline UCC & & & 44 & 17 & 107 & 83 & 13.6 & $\mid 10.7$ & 2.8 & 1.0 & 12 & 190 & 22 & 5.8 & 30 \\
\hline
\end{tabular}


Edegbai Aitalokhai Joel (2020) Differentiation of Sediment Source Regions in the Southern Benue Trough and Anambra Basin, Nigeria: Insights from Geochemistry of Upper Cretaceous Strata

Appendix 1c

\begin{tabular}{|c|c|c|c|c|c|c|c|c|c|c|c|c|c|c|c|}
\hline $\mathrm{S} / \mathrm{N}$ & Lithostratigraphic Unit & Location & Th/Sc & $\mathrm{Zr} / \mathrm{Sc}$ & $\mathrm{La} / \mathrm{Sc}$ & $\mathrm{Pb} / \mathrm{Zn}$ & K/Al & $\mathrm{Mg} / \mathrm{K}$ & $\mathrm{Mg} / \mathrm{Ti}$ & $\mathrm{Pb} / \mathrm{Nb}$ & $\mathbf{P b} / \mathrm{Sn}$ & $\mathrm{Na} / \mathrm{Al}$ & $\mathrm{Na} / \mathrm{K}$ & $\mathrm{Nb} / \mathrm{Ta}$ & $\mathrm{Nb} / \mathrm{W}$ \\
\hline U1 IA & \multirow{2}{*}{$\begin{array}{l}\text { Mamu } \\
\text { Formation }\end{array}$} & \multirow{3}{*}{$\begin{array}{l}\text { Western margin } \\
\quad(\text { Marsh } \\
\text { subenvironment })\end{array}$} & 1.64 & 19.24 & 5.58 & 1.99 & 0.04 & 0.21 & 0.07 & 0.92 & 7.72 & 0.002 & 0.05 & 14.4 & 14.4 \\
\hline U1 1C & & & 1.97 & 26.17 & 7.32 & 1.56 & 0.04 & 0.21 & 0.07 & 0.78 & 6.84 & 0.002 & 0.06 & 14.0 & 16.5 \\
\hline U1 2A & & & 1.87 & 24.54 & 6.74 & 2.6 & 0.04 & 0.18 & 0.06 & 0.74 & 6.16 & 0.002 & 0.05 & 15.1 & 15.9 \\
\hline U1 2B & & & 1.60 & 22.26 & 6.14 & 1.47 & 0.04 & 0.18 & 0.05 & 0.99 & 8.83 & 0.002 & 0.06 & 14.8 & 15.7 \\
\hline U1 2C & & & 1.40 & 19.62 & 5.31 & 3.6 & 0.04 & 0.2 & 0.06 & 1.03 & 9.26 & 0.002 & 0.05 & 15.0 & 16.5 \\
\hline $\mathrm{U} 13 \mathrm{~A}$ & & & 1.38 & 20.68 & 5.41 & 1.71 & 0.04 & 0.19 & 0.07 & 0.76 & 6.92 & 0.002 & 0.05 & 15.3 & 15.3 \\
\hline U1 3B & & & 1.23 & 19.33 & 4.96 & 1.91 & 0.04 & 0.19 & 0.08 & 0.82 & 6.65 & 0.002 & 0.06 & 14.0 & 15.9 \\
\hline U1 5A & & & 1.14 & 12.36 & 3.29 & 1.94 & 0.03 & 0.2 & 0.08 & 0.95 & 7.1 & 0.002 & 0.06 & 13.9 & 15.3 \\
\hline U1 5B & & & 1.03 & 11.53 & 2.76 & 2.31 & 0.03 & 0.2 & 0.09 & 1.0 & 6.93 & 0.002 & 0.06 & 13.8 & 13.8 \\
\hline $\mathrm{U} 16 \mathrm{~A}$ & & & 1.11 & 12.92 & 3.61 & 1.97 & 0.03 & 0.2 & 0.08 & 0.87 & 6.24 & 0.001 & 0.04 & 14.0 & 13.4 \\
\hline U1 7A & & & 1.09 & 8.87 & 3.15 & 0.11 & 0.02 & 0.32 & 0.1 & 0.98 & 7.44 & 0.002 & 0.09 & 13.6 & 14.4 \\
\hline U1 7B & & & 1.05 & 12.17 & 3.84 & 0.31 & 0.03 & 0.24 & 0.08 & 0.89 & 7.00 & 0.002 & 0.05 & 15.3 & 15.3 \\
\hline U1 8A & & & 1.16 & 9.73 & 2.99 & 0.17 & 0.02 & 0.29 & 0.09 & 0.94 & 6.64 & 0.001 & 0.03 & 14.2 & 17.0 \\
\hline U1 8B & & & 1.11 & 11.92 & 4.02 & 0.2 & 0.03 & 0.32 & 0.09 & 0.91 & 7.49 & 0.003 & 0.09 & 14.5 & 14.5 \\
\hline U1 8C & & & 1.38 & 14.22 & 4.21 & 0.08 & 0.03 & 0.31 & 0.07 & 0.79 & 6.48 & 0.003 & 0.09 & 14.1 & 14.1 \\
\hline $\mathrm{U} 18 \mathrm{D}$ & & & 0.99 & 13.46 & 3.28 & 0.18 & 0.03 & 0.22 & 0.06 & 0.94 & 7.35 & 0.003 & 0.10 & 15.2 & 15.2 \\
\hline U1 9B & & & 1.18 & 13.32 & 3.90 & 0.83 & 0.03 & 0.18 & 0.05 & 0.98 & 8.05 & 0.001 & 0.05 & 14.5 & 14.5 \\
\hline U1 9C & & & 0.95 & 13.74 & 3.09 & 0.94 & 0.03 & 0.19 & 0.06 & 0.93 & 6.87 & 0.002 & 0.08 & 13.9 & 13.9 \\
\hline U1 10 & & & 1.48 & 15.17 & 5.29 & 3.34 & 0.01 & 0.21 & 0.04 & 1.11 & 7.65 & 0.001 & 0.07 & 14.4 & 13.8 \\
\hline U1 18 & & & 0.98 & 11.69 & 3.32 & 3.10 & 0.02 & 0.16 & 0.04 & 0.93 & 6.33 & 0.001 & 0.06 & 13.8 & 13.8 \\
\hline U1 19 & & & 1.12 & 13.85 & 3.62 & 2.61 & 0.02 & 0.19 & 0.04 & 0.83 & 5.44 & 0.001 & 0.04 & 15.0 & 16.5 \\
\hline AU-1a & & & 1.1 & 10.64 & 3.63 & 1.33 & 0.07 & 0.23 & 0.2 & 1.15 & 7.15 & 0.002 & 0.03 & 13.5 & 13.5 \\
\hline AU 2 & & & 0.84 & 8.38 & 1.88 & 0.97 & 0.07 & 0.23 & 0.25 & 1.05 & 6.24 & 0.002 & 0.03 & 14.7 & 13.9 \\
\hline Mean & & & 1.25 & 15.03 & 4.23 & 1.53 & 0.03 & 0.22 & 0.08 & 0.93 & 7.08 & 0.002 & 0.06 & 14.4 & 14.9 \\
\hline Median & & & 1.14 & 13.46 & 3.84 & 1.56 & 0.03 & 0.2 & 0.07 & 0.93 & 6.93 & 0.002 & 0.06 & 14.4 & 14.5 \\
\hline SD & & & 0.29 & 4.99 & 1.37 & 1.09 & 0.01 & 0.05 & 0.05 & 0.11 & 0.86 & 0.001 & 0.02 & 0.6 & 1.1 \\
\hline IM 2B & \multirow{2}{*}{$\begin{array}{l}\text { Mamu } \\
\text { Formation }\end{array}$} & \multirow{3}{*}{$\begin{array}{l}\text { Western margin } \\
\text { (Central Basin } \\
\text { subenvironment) }\end{array}$} & 1.07 & 6.58 & 1.85 & 0.92 & 0.07 & 0.22 & 0.25 & 1.29 & 7.07 & 0.002 & 0.02 & 13.3 & 12.8 \\
\hline $1 \mathrm{M} 2 \mathrm{C}$ & & & 1.24 & 7.71 & 2.54 & 0.74 & 0.08 & 0.23 & 0.24 & 1.28 & 7.62 & 0.002 & 0.03 & 13.7 & 13.1 \\
\hline $1 \mathrm{M} 2 \mathrm{D}$ & & & 1.31 & 7.04 & 2.61 & 0.67 & 0.08 & 0.24 & 0.28 & 1.54 & 8.58 & 0.002 & 0.03 & 14.0 & 15.4 \\
\hline $1 \mathrm{M} 2 \mathrm{E}$ & & & 1.16 & 6.40 & 2.63 & 0.38 & 0.07 & 0.31 & 0.36 & 1.29 & 7.20 & 0.002 & 0.03 & 13.5 & 12.9 \\
\hline IM 4A & & & 1.77 & 8.93 & 4.58 & 0.74 & 0.07 & 0.25 & 0.25 & 1.31 & 7.44 & 0.003 & 0.04 & 14.4 & 14.4 \\
\hline IM 11A & & & 2.06 & 10.09 & 4.09 & 0.36 & 0.05 & 0.37 & 0.34 & 1.85 & 7.33 & 0.002 & 0.04 & 13.9 & 15.6 \\
\hline IM 11B & & & 0.77 & 3.72 & 1.12 & 0.46 & 0.06 & 0.29 & 0.42 & 1.26 & 5.48 & 0.002 & 0.03 & 15.2 & 13.5 \\
\hline IM 11C & & & 1.26 & 4.64 & 3.63 & 0.32 & 0.09 & 0.30 & 0.51 & 1.72 & 7.45 & 0.002 & 0.03 & 14.4 & 14.4 \\
\hline IM 13A & & & 1.49 & 4.64 & 3.13 & 0.25 & 0.07 & 0.41 & 0.68 & 1.32 & 5.70 & 0.002 & 0.03 & 14.5 & 12.7 \\
\hline $1 \mathrm{M} \mathrm{13B}$ & & & 0.87 & 4.26 & 1.38 & 0.31 & 0.07 & 0.28 & 0.39 & 1.10 & 5.41 & 0.002 & 0.03 & 14.8 & 12.1 \\
\hline IM 14A & & & 1.16 & 5.03 & 3.61 & 0.20 & 0.09 & 0.30 & 0.50 & 1.83 & 9.02 & 0.003 & 0.03 & 14.1 & 12.5 \\
\hline IM 16A & & & 0.79 & 3.76 & 2.21 & 0.20 & 0.10 & 0.35 & 1.08 & 1.98 & 6.82 & 0.002 & 0.02 & 14.6 & 10.1 \\
\hline IM 16B & & & 0.73 & 4.49 & 1.93 & 0.25 & 0.10 & 0.30 & 0.89 & 1.95 & 7.75 & 0.002 & 0.02 & 15.9 & 9.9 \\
\hline $1 \mathrm{M} 16 \mathrm{C}$ & & & 0.83 & 5.74 & 1.74 & 0.49 & 0.10 & 0.24 & 0.65 & 1.85 & 7.17 & 0.002 & 0.02 & 14.0 & 12.1 \\
\hline $1 \mathrm{M} \mathrm{16D}$ & & & 1.05 & 6.35 & 2.37 & 0.62 & 0.10 & 0.22 & 0.53 & 1.20 & 5.32 & 0.002 & 0.02 & 15.0 & 11.5 \\
\hline IM 18a & & & 1.06 & 4.91 & 4.68 & 0.61 & 0.09 & 0.12 & 0.30 & 2.11 & 10.36 & 0.003 & 0.03 & 15.0 & 15.0 \\
\hline IM 18C & & & 0.73 & 3.74 & 1.25 & 1.38 & 0.05 & 0.22 & 0.27 & 2.09 & 7.97 & 0.001 & 0.03 & 15.0 & 10.7 \\
\hline
\end{tabular}


Edegbai Aitalokhai Joel (2020) Differentiation of Sediment Source Regions in the Southern Benue Trough and Anambra Basin, Nigeria: Insights from Geochemistry of Upper Cretaceous Strata

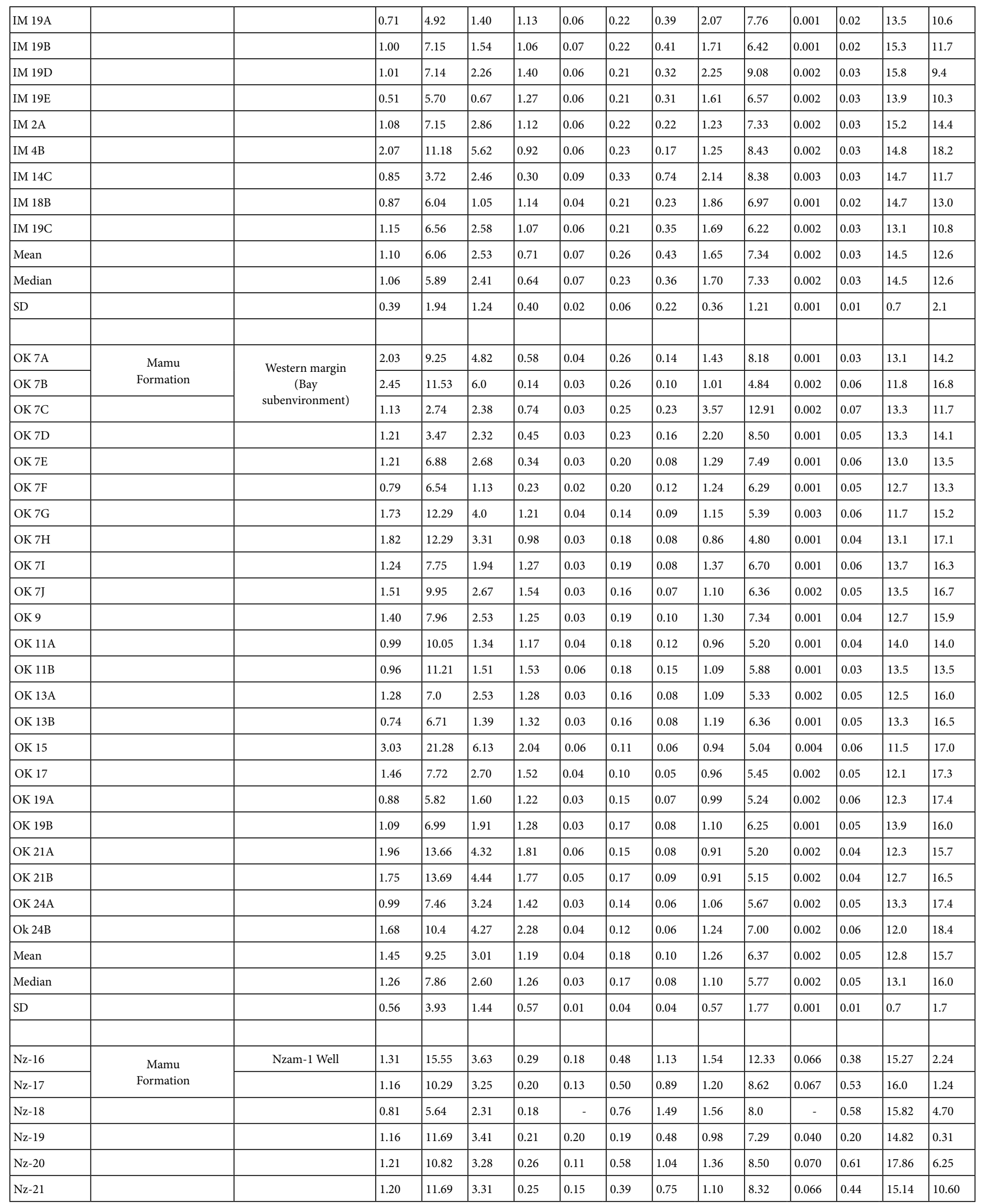


Edegbai Aitalokhai Joel (2020) Differentiation of Sediment Source Regions in the Southern Benue Trough and Anambra Basin, Nigeria: Insights from Geochemistry of Upper Cretaceous Strata

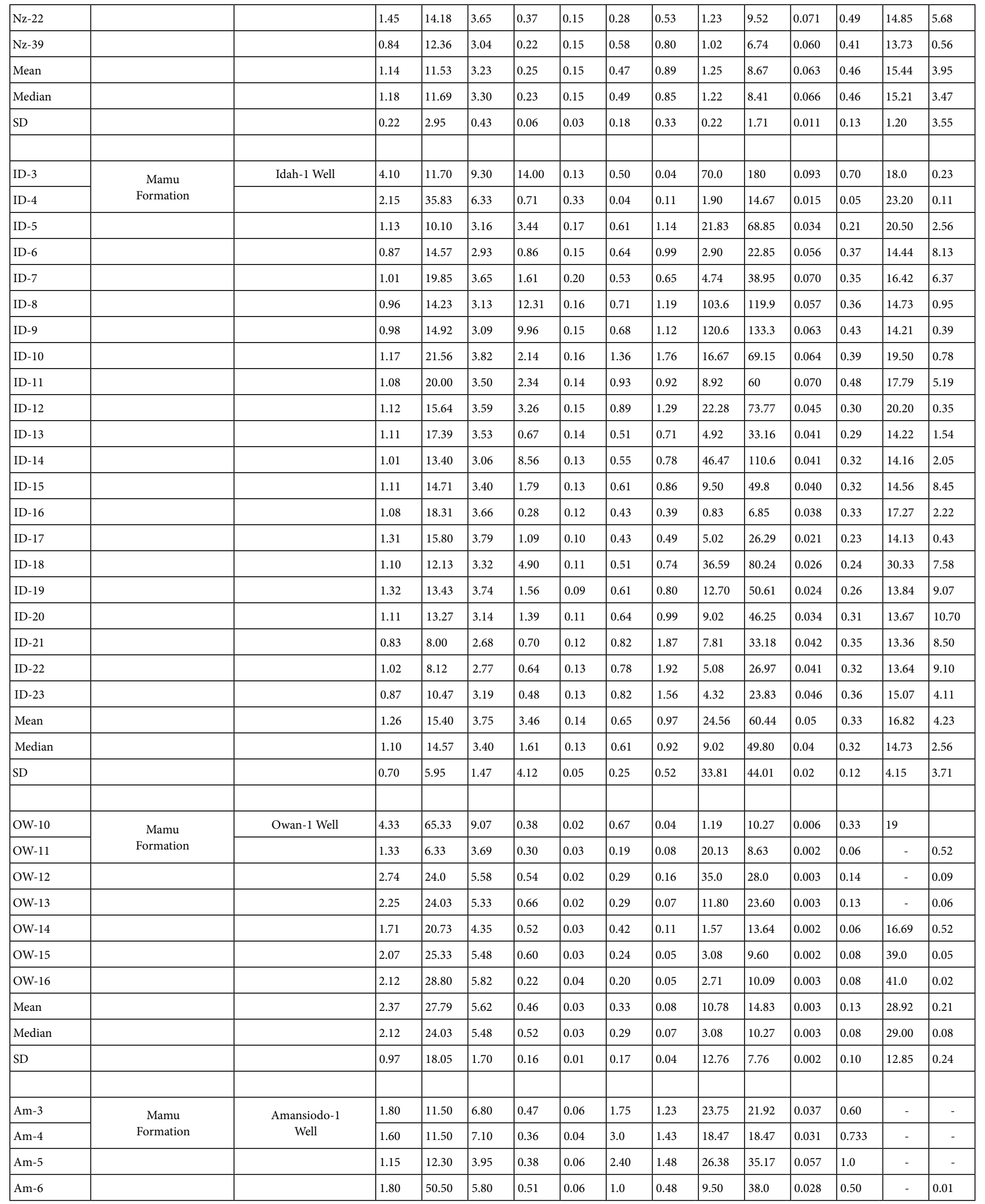


Edegbai Aitalokhai Joel (2020) Differentiation of Sediment Source Regions in the Southern Benue Trough and Anambra Basin, Nigeria: Insights from Geochemistry of Upper Cretaceous Strata

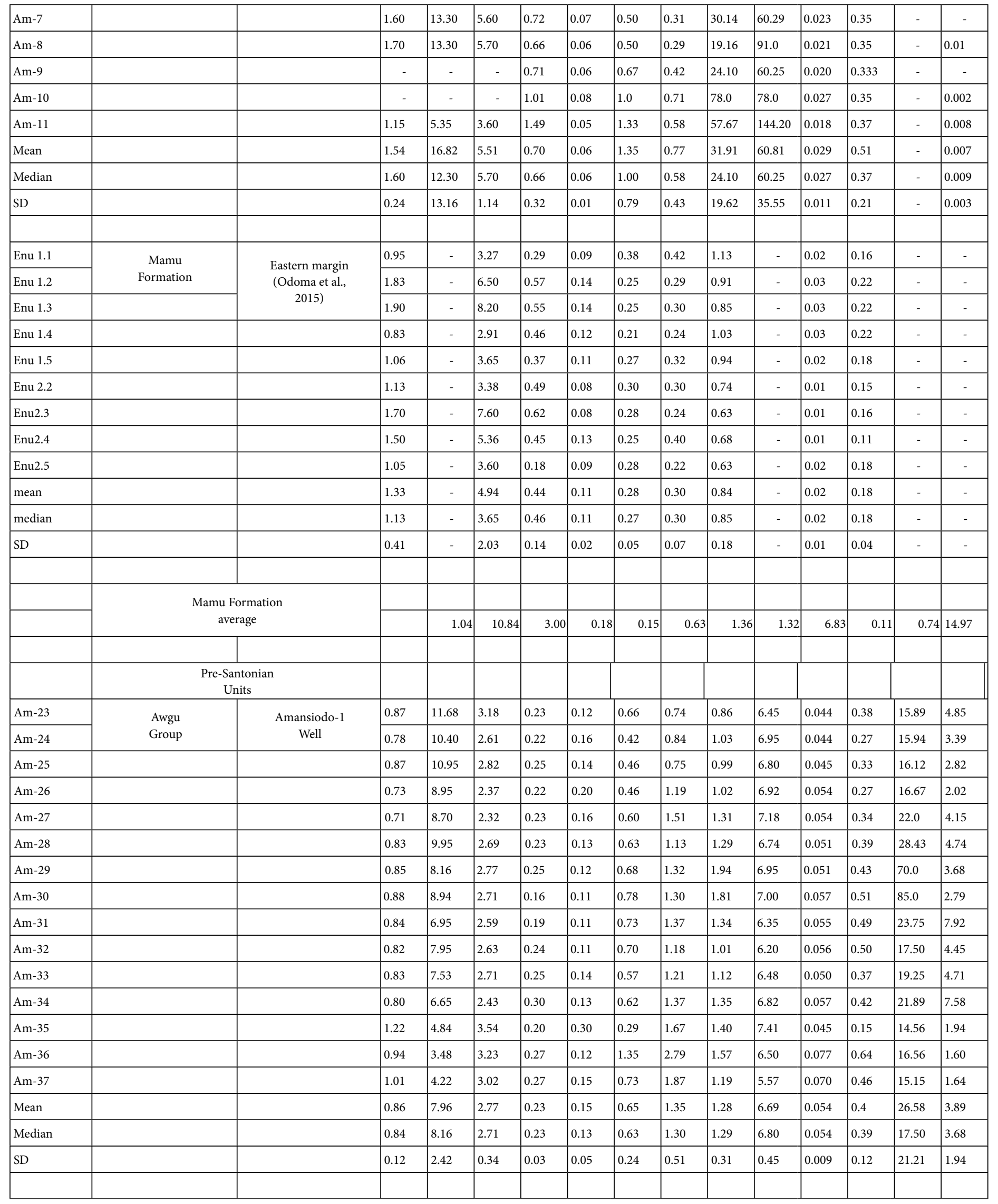


Edegbai Aitalokhai Joel (2020) Differentiation of Sediment Source Regions in the Southern Benue Trough and Anambra Basin, Nigeria: Insights from Geochemistry of Upper Cretaceous Strata

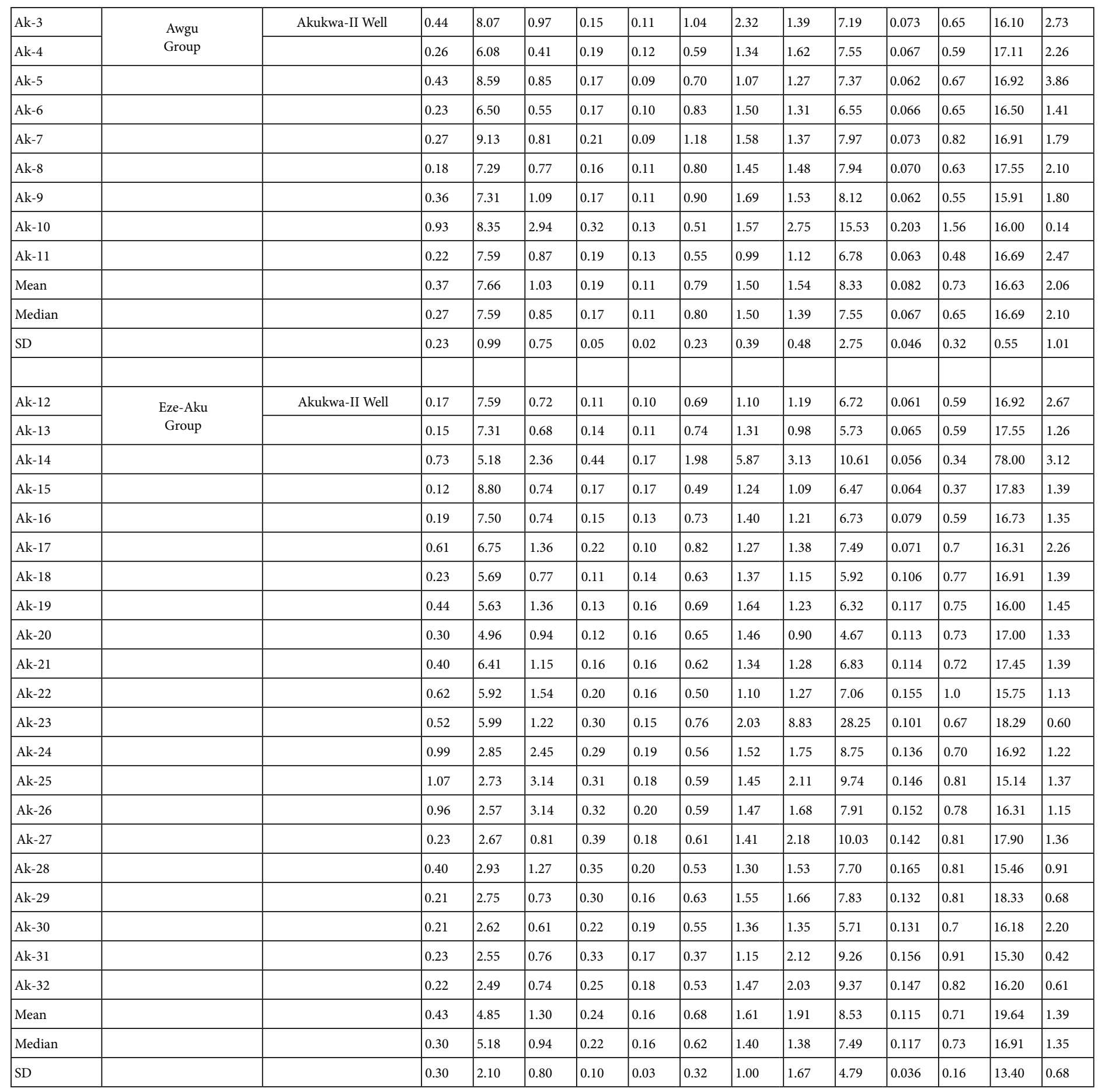

